\author{
UNIVERSIDADE DE SÃO PAULO \\ INSTITUTO DE FÍSICA DE SÃO CARLOS
}

MIRIAN DENISE STRINGASCI

Avaliação termográfica para a detecção de lesões cutâneas clinicamente semelhantes

São Carlos 

MIRIAN DENISE STRINGASCI

\section{Avaliação termográfica para a detecção de lesões cutâneas clinicamente semelhantes}

Tese apresentada ao Programa de PósGraduação em Física do Instituto de Física de São Carlos da Universidade de São Paulo, para obtenção do título de Doutora em Ciências.

Área de concentração: Física Aplicada Opção: Física Biomolecular

Orientador: Prof $\stackrel{a}{\text {. Dra }}$. Cristina Kurachi

Versão corrigida

(versão original disponível na Unidade que aloja o Programa)

São Carlos

2017 
AUTORIZO A REPRODUÇÃO E DIVULGAÇÃO TOTAL OU PARCIAL DESTE TRABALHO, POR QUALQUER MEIO CONVENCIONAL OU ELETRÔNICO PARA FINS DE ESTUDO E PESQUISA, DESDE QUE CITADA A FONTE.

Ficha catalográfica revisada pelo Serviço de Biblioteca e Informação do IFSC, com os dados fornecidos pelo(a) autor(a)

Stringasci, Mirian Denise

Aval iação termográfica para a detecção de lesões cutâneas clinicamente semelhantes / Mirian Denise Stringasci; orientadora Cristina Kurachi - versão corrigida - - São Carlos, 2017.

$$
116 \mathrm{p} \text {. }
$$

Tese (Doutorado - Programa de Pós-Graduação em Física Biomolecular) - - Instituto de Física de Sāo Carlos, Universidade de São Paulo, 2017

1. Termografia. 2. Lesões cutâneas. 3. Terapia Fotodinâmica. 4. Diagnóstico. 5. Câncer. I. Kurachi Cristina, orient. II. Título. 


\section{AGRADECIMENTOS}

Agradeço primeiramente a Deus, que me deu força e determinação para lutar por meus objetivos e concretizar meus sonhos, como a realização deste projeto.

Agradeço também a minha família, minha essência: minha mãe Eliana, meu irmão Thiago, meu avô Narciso e ao Marquinho, que sempre estiveram ao meu lado, nos momentos bons e ruins. Ao meu pai Jeremias e à minha avó Leotildes, que mesmo não estando mais presentes, fazem parte do que sou hoje e tiveram grande importância na minha formação pessoal. Amo e amarei sempre.

Ao Lê, meu esposo e companheiro, que está sempre presente me apoiando, dando conselhos e me acalmando nos momentos de desespero. Seu apoio e compreensão é essencial em minha vida. Obrigada, ao nosso anjo Gabrielzinho, que mesmo sendo tão pequeno, faz com que eu queira evoluir e buscar o meu melhor.

Às princesas do recanto por tornarem meus dias de trabalho muito mais leves e divertidos. Aos companheiros de viagem para Jahu que animaram as cansativas viagens de sextas-feiras.

Ao Didi e à Lili que acrescentaram muito conhecimento através de discussões e ideias. Eles, que dedicaram muito de seu tempo ajudando a buscar soluções de vários problemas que surgiram ao longo do projeto e a conduzir este trabalho para uma melhor abordagem.

Ao David pela importante ajuda no processamento das imagens das lesões. Através destas análises foi possível chegar a uma resposta para o problema da discriminação das lesões.

À Dra Ana Gabriela que ajudou a tornar a realização deste trabalho possível, que aceitou fazer parte deste projeto com muito entusiasmo, realizando a seleção de todas as lesões que foram registradas. Minhas permanências em seu ambulatório tiveram ricas discussões e aprendizagem, pessoal e profissional.

Ao Professor Vanderlei que contribuiu imensamente com este trabalho através de ideias e discussões. Agradeço também pela oportunidade de trabalhar em seu 
grupo, onde pude usufruir da infraestrutura dos laboratórios de Biofotônica e convivendo com pessoas de diferentes formações, o que favorece com que seus alunos desenvolvam projetos interdisciplinares.

À minha orientadora Professora Cristina que esteve sempre presente, orientando e ajudando a encontrar soluções simples e claras de problemas aparentemente sem soluções.

Aos amigos de laboratório, pela amizade e pela troca de conhecimento e experiências.

À biblioteca do IFSC por toda atenção e dedicação nas correções do texto.

E a CAPES pelo auxílio financeiro por meio da bolsa de doutorado. 
"A conquista é um acaso que talvez dependa mais das falhas dos vencidos do que do gênio do vencedor." 



\section{RESUMO}

STRINGASCI, M. D. Avaliação termográfica para a detecção de lesões cutâneas clinicamente semelhantes. 2017. 116 p. Tese (Doutorado em Ciências) - Insttituto de Física de São Carlos, Universidade de São Paulo, São Carlos, 2017.

Dentre os diferentes tipos, o câncer de pele é o tipo de câncer com maior incidência no mundo. É crescente o interesse em explorar técnicas que auxiliem no diagnóstico de lesões malignas e pré-malignas, assim como no monitoramento da eficácia dos tratamentos existentes. As lesões tumorais apresentam temperatura diferente se comparadas a tecidos normais e, com o desenvolvimento de detectores térmicos cada vez mais sensíveis e com melhor qualidade de resolução, a termografia tem se apresentado como uma abordagem de interesse cada vez maior. Os objetivos deste estudo foram: (1) avaliar o uso do imageamento termográfico para o monitoramento e diferenciação de lesões clinicamente semelhantes e (2) analisar a eficiência da terapia fotodinâmica durante o tratamento. Um monitoramento piloto por termografia do crescimento de tumores de Ehrlich (hipotérmicos) injetados no dorso de camundongos Swiss mostrou capacidade para a detecção de tumores a partir de $4 \mathrm{~mm}$ de diâmetro. $\mathrm{Na}$ avaliação de lesões clínicas, foi investigada a discriminação de pares de lesões cutâneas potencialmente semelhantes clinicamente: CBC versus nevo intradérmico, carcinoma espinocelular (CEC) versus queratose actínica (QA) e queratose seborreica (QSP) versus melanoma. As lesões de CEC foram discriminadas com maior facilidade, apresentando aumento da temperatura na área da lesão em comparação com a região adjacente, enquanto as outras lesões clinicamente identificadas como $\mathrm{QA}$, que podem evoluir para CEC, quase não se diferenciam termicamente do tecido saudável circundante. Uma rotina de processamento das imagens das lesões utilizando um classificador de rede neural mostrou capacidade de diferenciar as lesões dos tipos CBC versus nevo em $67,2 \%$ dos casos; em $80 \%$ para as lesões de CEC versus QA, e em 50\% para as lesões QSP versus melanoma. O monitoramento da terapia fotodinâmica (TFD) foi realizado em lesões clínicas de CBC tratadas em duas sessões. Verificou-se que a região da lesão fica mais evidente termicamente ao longo do procedimento, e as definições das bordas da lesão tornam-se mais delimitadas após o término da iluminação. Com a obtenção das imagens térmicas de TFD criou- 
se um modelo simplificado para estimar a energia convertida nos processos de transferência de energia envolvidos na TFD. Mesmo com as aproximações realizadas, mostrou-se que a maior parte da energia depositada foi convertida em ação fotodinâmica $(53,8 \%)$, seguida da parcela que foi dissipada pela perfusão do sangue $(37,2 \%)$, mostrando que a maior parte da energia depositada no tecido durante 0 procedimento é incorporada ao efeito fotodinâmico. Esta é uma evidencia de que a ação fotodinâmica não apresenta componente térmica relevante, aspecto importante para o estudo de seus mecanismos.

Palavras-chave: Termografia. Lesões cutâneas. Terapia Fotodinâmica. Diagnóstico. Câncer. 


\begin{abstract}
\end{abstract}
STRINGASCI, M. D. Thermographic evaluation for the detection of clinically similar cutaneous lesions. 2017. 116 p. Tese (Doutorado em Ciências) - Insttituto de Física de São Carlos, Universidade de São Paulo, São Carlos, 2017.

Among the different cancer types, skin cancer is the most prevalent type of cancer in the world. In most cases, the survival rates are higher when the diagnosis occurs in the early stages of the disease. Thus, there is a growing interest in techniques that aid in the diagnosis of malignant and premalignant lesions, as well as in monitoring the efficacy of existing treatments. Concerning tumor diagnosis, tumor lesions present different temperature compared to normal tissues. Thermography has been presented as an approach of increasing interest due to the development of thermal detectors with better resolution quality and increased sensitivity. The objective of this study was therefore to evaluate the possibility of differentiating clinically similar lesions and monitoring the efficiency of photodynamic therapy during the treatment by using thermographic images and neural network classifiers. A monitoring of the growth of Ehrlich (hypothermic) tumors injected into the Swiss mouse back using thermography showed the technique is able to detect tumors from $4 \mathrm{~mm}$ in diameter. For the evaluation of clinical lesions, the discrimination of potentially clinically similar cutaneous lesions: BCC versus intradermal nevus, squamous cell carcinoma (SCC) versus actinic keratosis (AK) and seborrheic keratosis (PSK) versus melanoma were investigated. SCC lesions were more easily discriminated, showing an increase of temperature in the lesion area compared to the adjacent region, while the lesions that were clinically identified as AK (which can possible progress towards SCC lesions) can hardly be thermally differentiated differ thermally from the surrounding healthy tissue. This is a very relevant result, given the great difficulty in diagnosing SCC lesions by the standard dermatoscopy technique. An images processing routine using a neural network classifier showed the ability to differentiate lesions between BCC and nevus types in $67.2 \%$ of the cases; $80 \%$ for SCC versus AK lesions, and $50 \%$ for PSK lesions versus melanoma. The monitoring of photodynamic therapy (PDT) was performed in $\mathrm{BCC}$ lesions treated in two sessions. The lesion region becomes more thermally evident throughout the procedure, and the definitions of the lesion edges become more 
clearly delimited visually after the end of the illumination. By obtaining the thermal images of PDT a model was created to calculate the amount of light energy converted to heat, damage, and other energy transfer processes involved in the PDT. Despite the approximations made, it was shown that most of the deposited energy was converted into photodynamic action (53.8\%), followed by the portion cleared from the irradiated tissue by the blood perfusion (37.2\%), showing that most of the energy deposited in the tissue during the procedure is incorporated into the photodynamic effect. This is an evidence that the photodynamic action does not present a relevant thermal component, an important aspect for the study of its mechanisms.

Keywords: Thermography. Skin lesions. Photodynamic Therapy. Diagnoise. Cancer. 


\section{LISTA DE FIGURAS}

Figura 1 - Faixa do espectro de emissão de um corpo e de detecção da termografia.

Figura 2 - (A) Imagem de uma lesão de CBC e (B) Imagem de um nevo intradérmico.

Figura 3 - (A) Imagem de CEC e (B) Imagem de QA

Figura 4 - (A) Imagem de lesão de melanoma e (B) imagem de uma QSP 33

Figura 5 - Diagrama de Jablonski simplificado.

Figura 6 - Termovisor utilizado

Figura 7 - Exemplo de áreas delimitadas na área da lesão e no tecido sadio ao redor utilizando a rotina elaborada em MATLAB®

Figura 8 - Fluxograma das etapas de análises e determinação de método de discriminação das imagens das lesões clinicamente semelhantes...

Figura 9 - Imagem de infravermelho do camundongo Swiss (A) logo após tricotomia e em (B), (C), (D) e (E), imagens 2, 4, 7 e 9 dias após a injeção de células de tumor de Ehrlich, (F) imagem de luz branca 9 dias após a injeção.

Figura 10 - (A) Variação da temperatura média na região do crescimento do tumor em relação ao valor inicial e variação do diâmetro médio do tumor, com dados representando média dos nove animais e (B) Ajuste da curva variação da temperatura pela variação do tamanho do tumor em diâmetro.

Figura 11 - Dorso do camundongo durante iluminação $(A)$, (B) 2, (C) 4, (D) 6, (E) 8, (F) 10, (G) 12, (H) 14, (I) 16, (J) 18 e (K) 20 minutos; e após iluminação (L) 1, (M) 2, (N) 3 e (O) 4 minutos.

Figura 12 - (A) e (B) Curvas de aquecimento durante iluminação e resfriamento após o término da iluminação dos animais sem administração prévia do Metil-ALA, respectivamente; (C) e (D) curvas de aquecimento durante iluminação e resfriamento após o término da iluminação dos animais durante o procedimento de TFD em tecido normal; (E) e (F) curvas de aquecimento durante iluminação e resfriamento após o término da iluminação dos animais durante o procedimento de TFD em que foi realizada curetagem de $1 \mathrm{~cm}$ de diâmetro para simular uma lesão.

Figura 13 - Imagens termográficas de lesões do tipo CBC nodular.

Figura 14 - (A) Imagem de luz branca de uma lesão do tipo CBC nodular, (B) imagem de infravermelho da lesão com valores de temperatura em alguns pontos da imagem, $(\mathrm{C})$ reta traçada cortando o centro da 
lesão, e (D) seu respectivo gráfico de temperatura em função dos pixels da imagem, em uma linha que atravessa o centro da lesão. A barra lateral à direita indica a escala de temperatura compreendida nas imagens (B) e (C)

Figura 15 - Imagens termográficas de lesões do tipo nevo intradérmico.

Figura 16 - (A) Imagem de luz branca de uma lesão do tipo nevo intradérmico, (B) imagem de infravermelho da lesão com valores de temperatura em alguns pontos da imagem, $(C)$ reta traçada cortando o centro da lesão, e (D) seu respectivo gráfico de temperatura em função dos pixels da imagem. A barra lateral à direita indica a escala de temperatura compreendida nas imagens $(B)$ e $(C)$

Figura 17 - Imagens termográficas de lesões do tipo CEC ................................

Figura 18 - (A) Imagem de luz branca de uma lesão do tipo CEC, (B) imagem de infravermelho da lesão com valores de temperatura em alguns pontos da imagem, (C) reta traçada cortando o centro da lesão, e (D) seu respectivo gráfico de temperatura em função dos pixels da imagem. A barra lateral à direita indica a escala de temperatura compreendida nas imagens (B) e (C)

Figura 19 - Imagens termográficas de lesões do tipo QA. As lesões exibidas em (B) e (C) apresentam regiões com menores temperatura devido à presença de crostas, enquanto as lesões exibidas em (A) e (D) apresentam pouca diferença de temperatura em relação ao tecido ao redor.

Figura 20 - (A) Imagem de luz branca de uma lesão do tipo QA, (B) imagem de infravermelho da lesão com valores de temperatura em alguns pontos da imagem, (C) reta traçada cortando o centro da lesão, e (D) seu respectivo gráfico de temperatura em função dos pixels da imagem. A barra lateral à direita indica a escala de temperatura

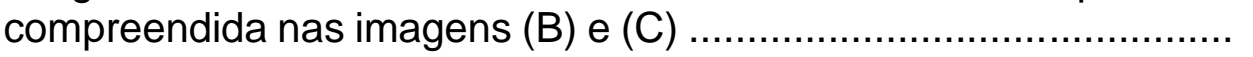

Figura 21 - Imagens termográficas de lesões do tipo melanoma........................

Figura 22 - Imagens de infravermelho (A) e de luz branca (B) de uma lesão de melanoma sem pigmentação em uma paciente albina.

Figura 23 - Imagens de infravermelho (A) e de luz branca (B) de uma lesão de melanoma subcutânea.

Figura 24 - (A) Imagem de luz branca de uma lesão do tipo melanoma, (B) imagem de infravermelho da lesão com valores de temperatura em alguns pontos da imagem, $(C)$ reta traçada cortando o centro da lesão, e (D) seu respectivo gráfico de temperatura em função dos pixels da imagem. A barra lateral à direita indica a escala de temperatura compreendida nas imagens $(B)$ e (C)

Figura 25 - Imagens termográficas de lesões do tipo QSP. 
Figura 26 - (A) Imagem de luz branca de uma lesão do tipo melanoma, (B) imagem de infravermelho da lesão com valores de temperatura em alguns pontos da imagem, (C) reta traçada cortando o centro da lesão, e (D) seu respectivo gráfico de temperatura em função dos pixels da imagem. A barra lateral à direita indica a escala de temperatura compreendida nas imagens $(B)$ e (C)

Figura 27 - Matriz de confusão obtida pelo classificador SVM usando o software Weka para os pares (a) BCV vs Nl; (B) CEC vs QA e (c) melanoma vs QSP. As linhas mostram o tipo de lesão que é e as colunas mostram o tipo que a lesão foi classificada. Os números verdes na coluna da esquerda mostram a sensibilidade (linha superior) e a especificidade (linha inferior)

Figura 28 - Curvas COR obtidas pelo classificador SVM usando o software Weka para os pares (a) CBC vs NI; (B) CEC vs QA e (c) melanoma vs QSP.

Figura 29 - Imagem de termografia de CBC nodular: (A) inicial (1로 sessão), (B) após a incubação da droga ( $1^{\underline{a}}$ sessão), (C) após a iluminação ( $1^{\mathrm{a}}$ sessão); (D) inicial $2^{\underline{a}}$ sessão, (E) após a incubação da droga ( $2^{\underline{a}}$ sessão) e (F) após a iluminação (2ª sessão)

Figura 30 - Imagem de termografia de CBC superficial (A) inicial, (B) após a incubação da droga e $(C)$ após a iluminação durante a primeira sessão; e (D) inicial, (E) após a incubação da droga e (F) após a iluminação durante a segunda sessão.

Figura 31 - Durante a primeira sessão: (A) imagem de luz branca da lesão no início do tratamento, $(B)$ imagem de fluorescência após incubação do Metil-ALA, imagens de termografia (C) da lesão inicial, (D) após a incubação, (E) após a iluminação; durante a segunda sessão: $(F)$ imagem de luz branca da lesão no início do tratamento, $(G)$ imagem de fluorescência após incubação do Metil-ALA, imagens de termografia $(\mathrm{H})$ da lesão inicial, (I) após a incubação, $(J)$ após a iluminação

Figura 32 - Temperatura da região da lesão e na região adjacente durante a primeira sessão e a segunda sessão da Terapia Fotodinâmica (A) para as lesões com resposta completa ao tratamento e (B) para as lesões com resposta incompleta.

Figura 33 - (A) Diferença entre as temperaturas ao redor da lesão ( $\operatorname{Tr}$ ) e dentro da lesão (TI) no início dos procedimentos de primeira sessão (S1) e segunda sessão; (B) diferença entre as temperaturas ao redor da lesão (Tr) e dentro da lesão (TI) após a incubação do FS nos procedimentos de primeira sessão (S1) e segunda sessão e (C) diferença entre as temperaturas ao redor da lesão (Tr) e dentro da lesão (TI) após os procedimentos de TFD de primeira sessão (S1) e segunda sessão. 
Figura 34 - Esquema das regiões que possuem comportamento térmico

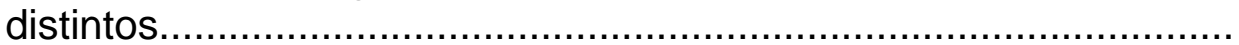

Figura 35 - (A) e (B) Variação de temperatura do período durante e após iluminação de pele sadia do antebraço de 3 voluntários, respectivamente; (C) e (D) variação de temperatura do período durante e após iluminação na área da lesão em procedimento de TFD; $(E)$ e $(F)$ variação de temperatura do período durante e após iluminação na área ao redor da lesão em procedimento de TFD

Figura 36 - (A) Local da periferia da área iluminada em que foi realizada a curva de variação de temperatura e (B) exemplo de curva gerada.... 


\section{LISTA DE TABELAS}

Tabela 1 - Características térmicas de diferentes tecidos biológicos........ 27

Tabela 2 - Métricas usadas na rotina elaborada em MATLAB®................ 49

Tabela 3 - Variação da temperatura média das lesões nas regiões interior e circundante à lesão. "Diferença" representa a diferença média entre as temperaturas da lesão e de seu entorno.

Tabela 4 - Valores dos ajustes das curvas dos três voluntários para o aumento e decaimento de temperatura durante e após o período de iluminação.

Tabela 5 - Valores de ajustes para as curvas de variação de temperatura nas periferias das áreas iluminadas.

Tabela 6 - Siglas e valores usados para cada termo de energia convertida durante a iluminação do procedimento da TFD.... 95

Tabela 7 - Propriedades térmicas da pele

Tabela 8 - Valores das componentes de energias convertidas durante 0 procedimento de TFD calculadas. 

LISTA DE ABREVIATURAS E SIGLAS

\begin{tabular}{|c|c|}
\hline $\mathrm{K}$ & Kelvin \\
\hline${ }^{\circ} \mathrm{C}$ & graus Celsius \\
\hline$\mu \mathrm{m}$ & micrometros \\
\hline Q & taxa metabólica \\
\hline K & condutividade térmica \\
\hline$\rho_{\mathrm{s}}$ & densidade \\
\hline$c_{s}$ & capacidade específica de calor \\
\hline$\omega_{s}$ & taxa de perfusão do sangue \\
\hline$\sigma$ & constante de Stefan-Boltzmann \\
\hline$\varepsilon$ & emissididade \\
\hline$h$ & transferência de calor \\
\hline $\mathrm{CBC}$ & carcinoma basocelular \\
\hline CEC & carcinoma espinocelular \\
\hline $\mathrm{NI}$ & nevo intradérmico \\
\hline QA & queratose actínica \\
\hline QSP & queratose seborreica pigmentad \\
\hline TFD & terapia fotodinâmica \\
\hline FS & fotossensibilizador \\
\hline ALA & ácido aminolevulínico \\
\hline Metil-ALA & aminolevulinato de metila \\
\hline
\end{tabular}


PpIX protoporfirina IX

MSV máquina vetorial de suporte 


\section{SUMÁRIO}

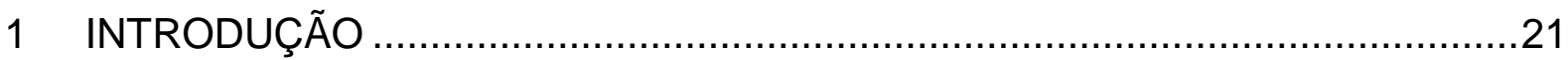

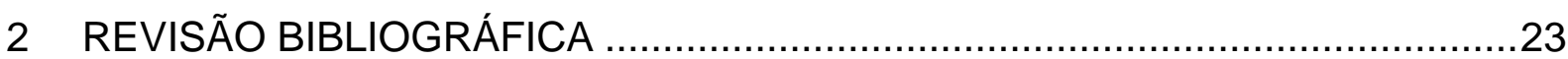

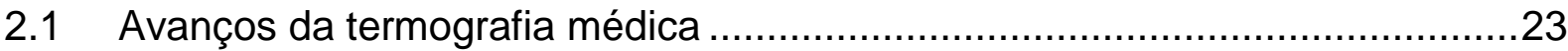

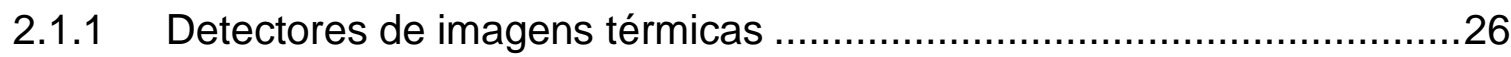

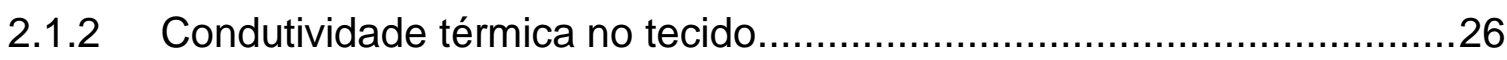

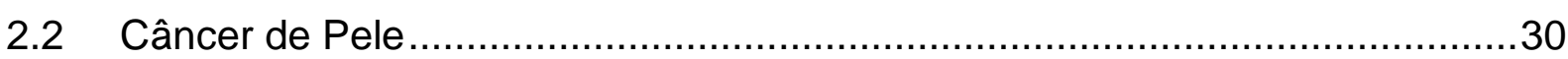

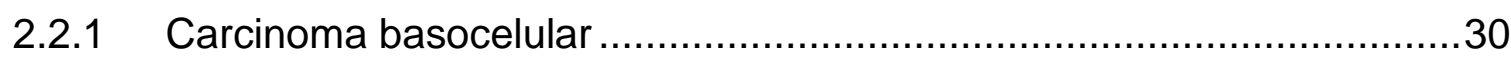

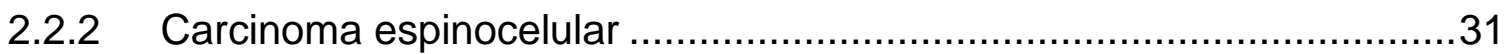

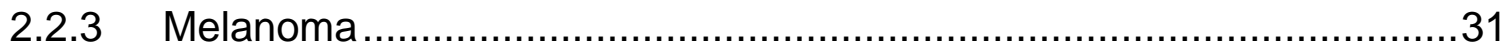

2.2.4 Diagnóstico de lesões clinicamente semelhantes.................................31

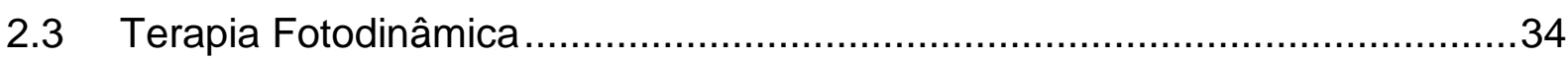

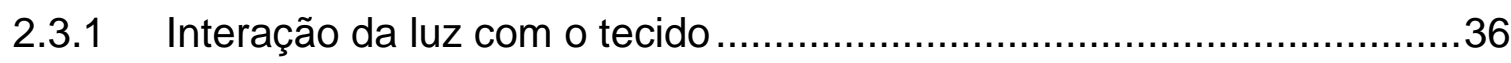

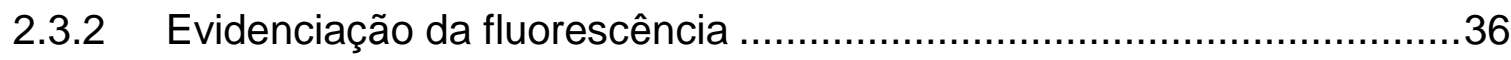

2.3.3 Importância da discriminação clínica de lesões ....................................37

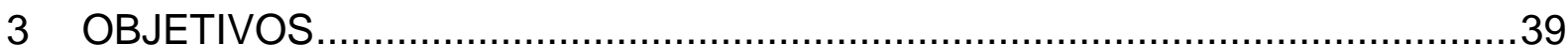

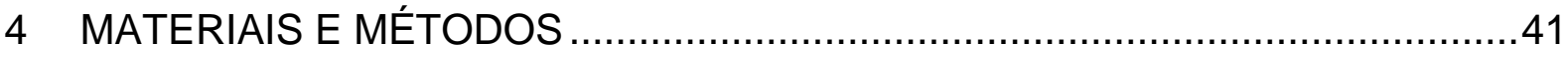

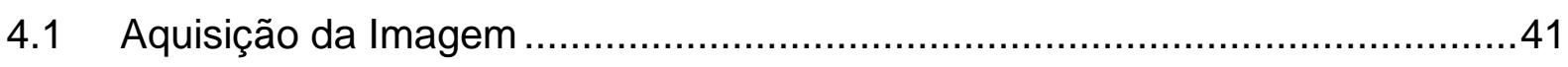

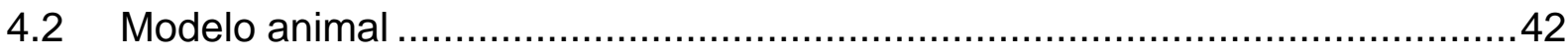

4.2.1 Anestesia e climatização do ambiente..............................................42

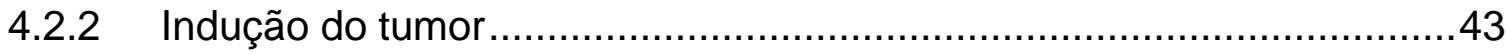

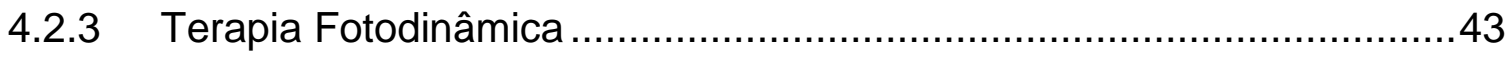

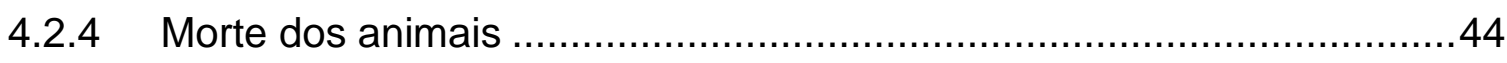

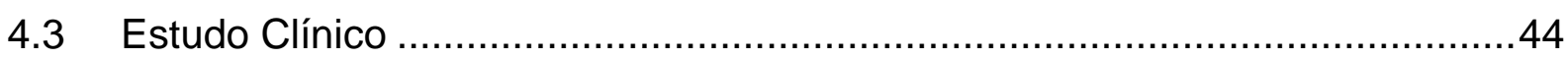

4.3.1 Discriminação de lesões clinicamente semelhantes .............................45

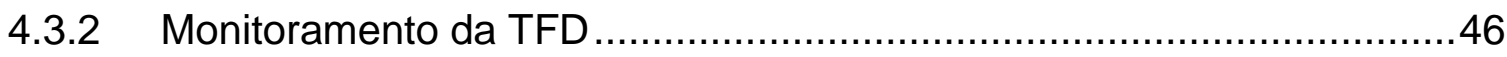

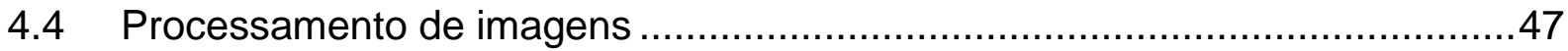

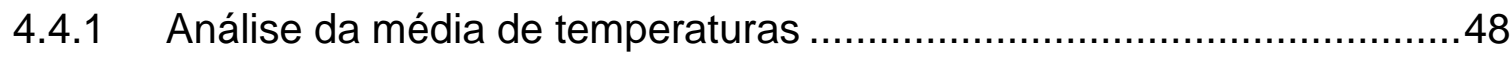

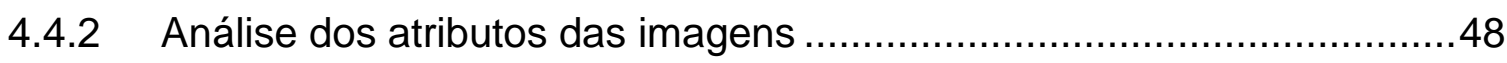

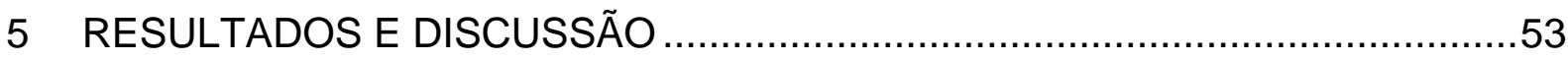

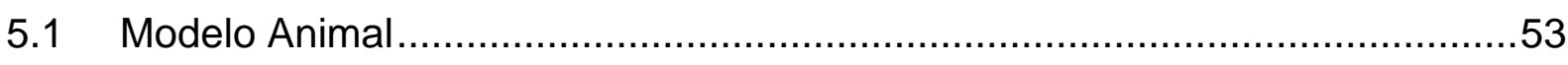

5.1.1 Monitoramento do crescimento tumoral............................................53

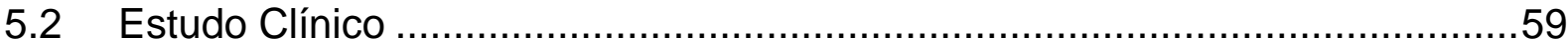


5.2.1 Discriminação de lesões clinicamente semelhantes .......................... 59

5.2.2 Avaliação da resposta da TFD ................................................ 81

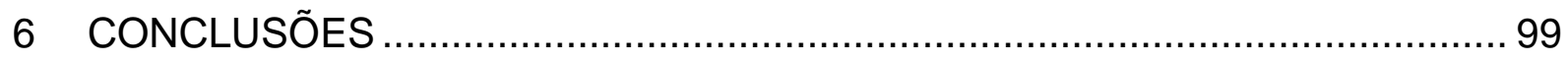

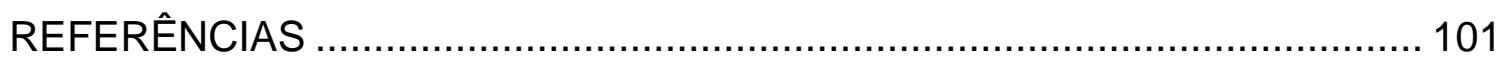

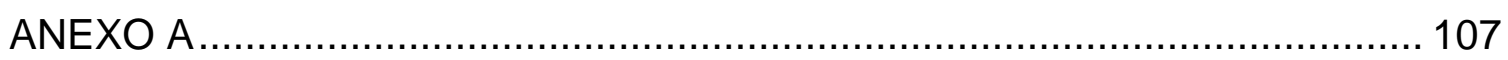

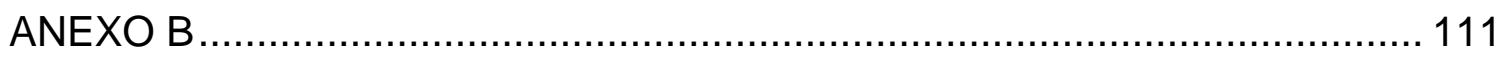

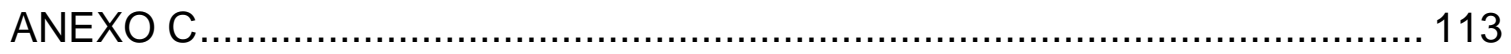

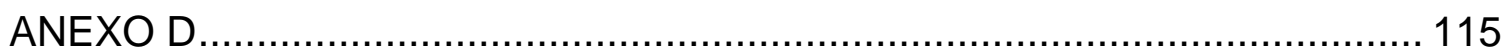




\section{INTRODUÇÃO}

É importante que haja avanços nas técnicas de diagnóstico para o câncer, doença responsável por $13 \%$ das mortes no mundo, ou seja, mais de 7 milhões de pessoas morrem anualmente da doença. (1) Na maioria dos casos, as chances de sobrevivência são maiores quando o câncer é diagnosticado em estágios iniciais, tornando os métodos de diagnóstico cada vez mais relevantes no combate à doença.

Dentre as tecnologias que existem atualmente para diagnóstico destas lesões, as imagens termográficas apresentam como vantagens não serem invasivas e por não emitirem doses de radiação ionizante nos tecidos do paciente.

Esta técnica existe desde a década de 1960, mas o avanço de outras técnicas de maior sensibilidade e especificidade, fez com que a termografia acabasse sendo deixada em segundo plano. Atualmente, vê-se novamente um grande avanço na área, uma vez que as câmeras termográficas mais modernas são capazes de diferenciar variações cada vez menores de temperatura.

Embora o crescente interesse na área, ainda se encontram poucos estudos na literatura voltados à dermatologia, tanto para a discriminação de lesões a serem diagnosticadas como para o monitoramento do tratamento de lesões malignas.

O câncer de pele é o tipo mais comum de tumor em termos de prevalência, apesar de não gerar tumores altamente invasivos, com exceção do melanoma e alguns subtipos do carcinoma de células escamosas. No Brasil, dados os desafios encontrados pelas políticas de saúde pública frente à demanda populacional, não há número suficiente de dermatologistas em postos de saúde, o que muitas vezes tem por consequência um diagnóstico tardio e maior morbidade.

O desenvolvimento das técnicas de obtenção de informação termográfica torna possível oferecer dados relevantes para o diagnóstico tecidual, uma vez que mudanças de temperatura podem estar correlacionadas com alterações patológicas, como inflamação tecidual e câncer e, portanto, torna a técnica atraente para tal aplicação, adicionalmente por se tratar de um procedimento não-invasivo, nãodestrutivo e de rápida resposta.

Esta ferramenta também tem o potencial de ser utilizada no monitoramento da resposta de modalidades de tratamento como a Terapia Fotodinâmica, uma vez que um dos efeitos deste método alternativo para tratamento de tumores é o dano vascular 
na região tratada, o qual produz efeitos que podem ser observados termicamente. Sendo esta uma técnica em franco desenvolvimento, a possibilidade de realizar este monitoramento pode se tornar o diferencial para garantir a eficiência de sua aplicação. 


\section{REVISÃo BIBLIOGRÁFICA}

\subsection{Avanços da termografia médica}

Os seres humanos são homeotérmicos, ou seja, são capazes de manter uma temperatura constante independente do meio circundante. Mudanças superiores a alguns graus Celsius na temperatura são claros indicadores de uma disfunção corporal, e podem perturbar processos químicos essenciais à manutenção da vida. (2)

Em meados do século III A.C. Hipócrates constatou que, ao utilizar lama molhada sobre o corpo, era possível observar uma secagem mais rápida em região de inchaço tumoral. Com isso, houve o reconhecimento médico da importância em evidenciar temperaturas elevadas. Durante séculos, esta habilidade permaneceu subjetiva e o conceito de medição da temperatura não foi desenvolvido até o século XVI. (2)

A transferência de calor pode ocorrer através de três processos principais: condução, em que o calor se propaga através de um meio material (o "condutor"), exigindo o contato entre dois objetos para permitir o fluxo de energia térmica por transferência de momento entre moléculas; convecção, no qual o calor se propaga também por transferência de momento molecular, mas por meio do movimento de massas fluidas de densidades diferentes; e a irradiação, onde o corpo troca calor com o meio ambiente através da emissão/absorção de radiação. No corpo humano, esse processo se dá como parte do processo normal de termorregulação, no qual a superfície corpórea troca calor com o ambiente, ocorrendo a maior parte desta transferência de calor no infravermelho distante. (2)

Qualquer corpo cuja temperatura esteja acima do zero absoluto (ou seja, $0 \mathrm{~K}$ ou $-273,15^{\circ} \mathrm{C}$ ) emite radiação infravermelha, devido ao movimento dos átomos e moléculas que o constituem. Quanto mais alta a temperatura, maior é o grau de agitação de átomos e moléculas, e mais radiação infravermelha é produzida por eles. O corpo humano, independentemente do fototipo da pele, possui emissividade da ordem de 0,98 , que é próximo da emissividade de um corpo negro perfeito, emitindo comprimentos de onda compreendidos entre 8 e $10 \mu \mathrm{m}$. (3) 
Uma câmera termográfica registra a distribuição de temperatura de um corpo utilizando a radiação infravermelha emitida pela sua superfície, detectando uma faixa de comprimentos de onda entre 7 e $14 \mu \mathrm{m}$ no infravermelho distante (Figura 1). A quantidade de energia dos fótons registrados é convertida em um sinal elétrico que é usado para calcular a temperatura real do corpo. (3) Com esta informação, é possível criar um mapa visual ou termograma de distribuição de temperaturas da superfície do corpo fotografado. (3)

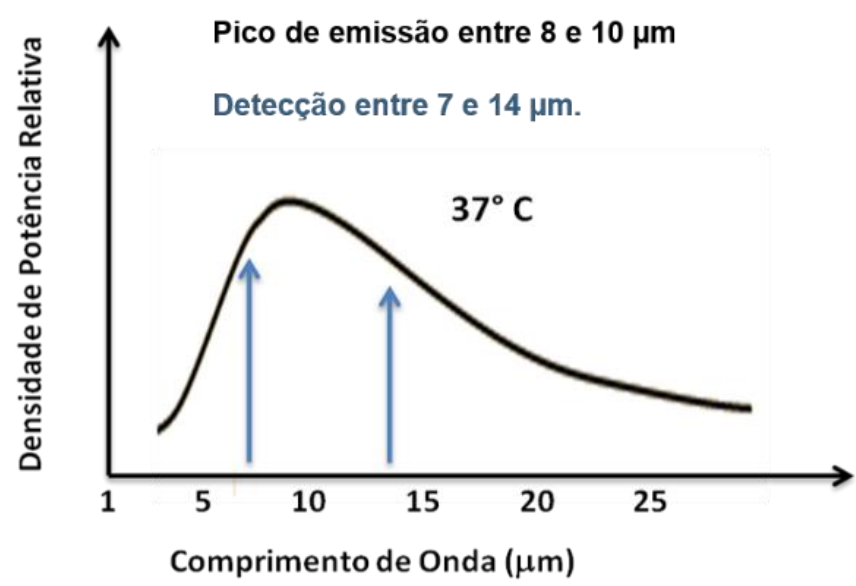

Figura 1 - Faixa do espectro de emissão de um corpo e de detecção da termografia. Fonte: Adaptada de BOSCHETTI. (4)

A literatura mostra que, em geral, as lesões tumorais apresentam diferença de temperatura se comparada com a parte sadia do tecido, o que se deve à grande vascularização comumente presente nestas lesões. (5) Isto acontece devido ao grande crescimento celular do tecido tumoral, que aumenta a demanda local por nutrientes, estimulando a angiogênese e, portanto, a vascularização na região, o que resulta em variação da temperatura. (3)

Em, 1928 foi documentada a primeira imagem de infravermelho em humano. E o primeiro sensor eletrônico para radiação infravermelha, desenvolvido na década de 1940, foi sendo aprimorado cada vez mais, com a finalidade de ser utilizado em sistemas de visão noturna por militares durante a Segunda Guerra Mundial na Alemanha, e para a Guerra do Vietnã. (2)

O uso médico da termografia começou em 1952 na Alemanha, quando o médico SCHWAMM e o físico REEH desenvolveram juntos um único detector de bolômetro infravermelho para medição térmica da superfície do corpo humano para 
fins de diagnóstico. (6) As primeiras utilizações de imagens termográficas na área de saúde foram realizadas para diagnóstico de câncer de mama na década de 1960. O avanço de outras técnicas (mamografia e ultrassonografia, por exemplo), que demonstraram maior sensibilidade e especificidade fizeram com que a termografia fosse deixada em segundo plano a partir do fim da década de 1970. (3)

Com o fim da Guerra Fria, os equipamentos de termografia haviam sido altamente desenvolvidos para uso como tecnologia militar e houve um grande incentivo para o uso nas aplicações médicas. As câmeras de imagem térmica tiveram melhorias tanto na qualidade de imagem quanto na velocidade de sua aquisição. Também foram incorporadas melhorias como lente de aumento com um anexo de macro e aumento do número de píxeis por elemento, produzindo alta resolução. (2)

Desde o fim dos anos 2000, avanços importantes na área vêm se apresentando, com o advento de câmeras termográficas mais modernas, que apresentam NETD (noise equivalent temperature difference, ou "diferença de temperatura equivalente a ruído") de até $25 \mathrm{mK}$, enquanto a maioria das aplicações clínicas exige NETD entre 80-200 mK. (7) Portanto, estes detectores são capazes de diferenciar variações da ordem de $0,025^{\circ} \mathrm{C}$. (3) O interesse na área vem aumentando desde então, pois além de se tratar de uma técnica não-invasiva, também é totalmente inofensiva à saúde, pois o paciente não recebe dose alguma de radiação ionizante, ao contrário de outras técnicas. (8-9)

Hoje, além do câncer de mama, a detecção de outros tipos de anormalidades vem sendo exploradas através do uso de imagens termográficas, pois sabe-se que a variação da temperatura da região da lesão pode ser alterada tanto pela presença do tumor, como por outros fatores como mudanças endócrino-metabólicas e presença de inflamação. (3) Com isso, vários outros estudos vêm sendo desenvolvidos, como nos casos de detecção de doenças vasculares, distúrbios osteomusculares relacionados ao trabalho (LER/DORT), reumatismo, melanoma, doenças da glândula tireoide, entre outros. (10-14) 


\subsubsection{Detectores de imagens térmicas}

Os detectores de infravermelho são geralmente divididos em dois tipos: detectores de fótons e detectores térmicos. Os detectores de fótons têm elevada relação sinal-ruído e resposta muito rápida, porém requerem sistema de resfriamento criogênico que é muito volumoso, pesado e caro. (15) As câmeras térmicas comerciais mais populares encontradas hoje usam os seguintes materiais detectores: (16)

- InSb: registrando infravermelho médio (comprimento de onda $5 \mu \mathrm{m}$ );

- ligas de $\mathrm{Hg}_{1-x} \mathrm{Cd}_{x} \mathrm{Te}$ : registrando infravermelho longo (entre 5 e $10 \mu \mathrm{m}$ );

- detectores de poços quânticos: registrando infravermelho longo (entre 5 e $10 \mu \mathrm{m}$ );

- bolômetros não resfriados: registrando infravermelho longo (10 $\mu \mathrm{m})$.

Os detectores do tipo bolômetro não resfriados têm demonstrado ser adequados para muitas aplicações médicas. (2) Estes detectores térmicos são sensíveis à radiação infravermelha emitida pelo corpo, de modo que os fótons absorvidos causam o aquecimento no detector, o que altera sua resistência elétrica. Um circuito no interior do bolômetro é utilizado para converter a corrente em saída de sinal. (16)

Desde os anos 1990 o interesse na termografia utilizando os bolômetros não resfriados vem aumentando drasticamente devido ao seu baixo custo. Por conta disto, estes detectores estão cada vez mais perto de atingir o desempenho que antes só era possível a partir dos detectores de fótons infravermelhos resfriados. (7) Os recentes avanços na tecnologia permitiram fabricar detectores térmicos cada vez mais sensíveis, que são operados à temperatura ambiente, sem a necessidade do sistema de resfriamento, o que diminui o consumo de energia e os custos. (15)

\subsubsection{Condutividade térmica no tecido}

A temperatura de um tecido biológico depende de várias propriedades deste, como a condutividade térmica e a perfusão sanguínea no mesmo. Com isso, sabe-se que várias alterações no tecido influenciam diretamente em sua temperatura, bem como nas alterações de suas propriedades térmicas, geradas por modificações 
estruturais e de composição advindas, por exemplo, de queimaduras ou processos de morte celular, ou ainda no fluxo sanguíneo, devido a estresse no tecido provocado, por exemplo, por isquemias. (17)

Um modelo tradicional que descreve a temperatura, T, na superfície do tecido, assumindo que este se encontra no equilíbrio térmico, é descrito pela Equação Biotérmica de Pennes (1):

$$
\kappa \nabla^{2} T+\rho_{s} c_{s} \omega_{s}\left(T_{\text {sangue }}-T\right)+Q=0
$$

onde $Q\left[\mathrm{~W} / \mathrm{m}^{3}\right]$ é a taxa metabólica, $\kappa[\mathrm{W} /(\mathrm{m} \mathrm{K})]$ é a condutividade térmica, e $\boldsymbol{\rho}_{\mathrm{s}}[\mathrm{kg} /$ $\left.\mathrm{m}^{3}\right], c_{s}[\mathrm{~J} /(\mathrm{kg} \mathrm{K})]$, e $\omega_{s}\left[\mathrm{~s}^{-1}\right]$ são a densidade, a capacidade específica de calor e taxa de perfusão do sangue, respectivamente. Tais fatores podem variar para os diversos tipos de tecido biológico; por isso, muitas vezes é possível identificar uma região alterada do tecido (como presença de tumor, queimaduras, problemas vasculares, entre outros) através de medidas da temperatura em sua superfície. (17-18) Em um tecido humano de mama, por exemplo, sabe-se que um tecido normal apresenta 450 $\mathrm{W} / \mathrm{m}^{3}$ de taxa metabólica e $0,00018 \mathrm{~s}^{-1}$ de taxa de perfusão, enquanto um tecido tumoral apresenta $29.000 \mathrm{~W} / \mathrm{m}^{3}$ e $0,009 \mathrm{~s}^{-1}$ respectivamente. (5)

Estas características térmicas são distintas para cada tipo de tecido e são exemplificadas na Tabela 1.

Tabela 1 - Características térmicas de diferentes tecidos biológicos.

\begin{tabular}{|c|c|c|c|}
\hline Tecido & $\begin{array}{c}\text { Condutividade térmica } \\
(\mathrm{W} / \mathrm{m} . \mathrm{K})\end{array}$ & $\begin{array}{c}\text { Calor específico } \\
\left(\mathrm{MJ} / \mathrm{m}^{3} . \mathrm{K}\right)\end{array}$ & Densidade $\left(\mathrm{kg} / \mathrm{m}^{3}\right)$ \\
\hline pele da mão & 0,960 & 3,77 & 1000 \\
\hline músculo & 0,642 & 3,94 & 1050 \\
\hline plasma & 0,599 & 4,05 & 1025 \\
\hline sangue total & 0,549 & 3,82 & 1050 \\
\hline núcleo abdominal & 0,544 & 3,89 & 1050 \\
\hline
\end{tabular}

Fonte: Adaptada de NANOMEDICINE (19)

A equação (1) mostra que tanto o metabolismo quanto a perfusão sanguínea afetam de forma importante a temperatura do tecido, criando uma fonte de calor interna: o metabolismo provoca a dissipação ou produção de calor no tecido, enquanto 
que o aumento da perfusão do sangue altera o aquecimento ou resfriamento do tecido. (18)

Além disso, na superfície do tecido, também ocorre a troca de calor com o ambiente externo através de processos de irradiação e propagação, descritos na Equação (2):

$$
\begin{aligned}
Q & =Q_{\text {irradiação }}+Q_{\text {propagação }} \\
& =\varepsilon \sigma\left(T_{\text {local }}^{4}-T_{\text {ar }}^{4}\right)+h\left(T_{\text {local }}+T_{\text {ar }}\right)
\end{aligned}
$$

onde $\sigma=5,67 \times 10^{-8}\left[\mathrm{~W} /\left(\mathrm{m}^{2} \mathrm{~K}^{4}\right)\right]$ é a constante de Stefan-Boltzmann, $\varepsilon$ é a emissividade e $h[\mathrm{~W} /(\mathrm{mK})]$ é o coeficiente de transferência de calor.

Desta forma, considerando todos os efeitos descritos nas equações (1) e (2), no geral, uma pessoa possui uma temperatura interna média de $37^{\circ} \mathrm{C}$, enquanto na superfície da pele esta temperatura fica comumente entre 32 e $34^{\circ} \mathrm{C}$ (de 3 a $5 \stackrel{\circ}{\circ} \mathrm{C}$ abaixo da média interna). $(5,18)$ Além disso, diversos outros fatores biológicos podem contribuir na troca de calor corpórea com o meio externo, como a respiração e a evaporação do suor, os quais são mecanismos de autorregulação de calor do organismo, tornando esta uma questão muito mais complexa do que a mera transferência de calor tecidual. (20)

Assim, existe uma grande heterogeneidade de valores de temperatura em função da localização corpórea. Esses valores podem variar de acordo com o sítio anatômico, entre regiões mais ou menos vascularizadas, além das próprias diferenças entre indivíduos que podem variar de acordo com o gênero e a idade. (20) Vários estudos utilizam as temperaturas das regiões contralaterais (ou seja, comparação da mesma região nos lados direitos e esquerdo do corpo) para evidenciação de alguma anormalidade, porém, sabe-se que naturalmente estas regiões podem apresentar diferenças de até $0,5 \stackrel{\circ}{\mathrm{C}}$ pelo fato do lado esquerdo ser mais próximo ao coração. (21) Portanto, é natural que uma das grandes dificuldades da utilização de medidas térmicas para o diagnóstico médico seja saber determinar se pequenas variações na temperatura de uma determinada região se encontram dentro ou fora de um padrão de normalidade e, desta forma, ser capaz de fazer diagnósticos precoces de algumas doenças quando a alteração térmica ainda é pouco evidente.

A radiação infravermelha emitida por uma superfície do corpo depende de fatores como umidade, temperatura e fluxo de ar no local, por isso existe uma 
necessidade de que a termografia seja sempre realizada em ambiente controlado e que o mesmo protocolo seja seguido para que se possa ter uma comparação fidedigna de imagens. Um tempo de climatização térmica é necessário para o paciente atingir o equilíbrio térmico. São encontrados vários protocolos exercidos por diferentes grupos de pesquisadores e estes utilizam tempo de espera variando de 5 a 20 minutos com temperaturas variando de 19 a $25^{\circ} \mathrm{C}$. (21)

Desde os primeiros usos da termografia até os dias atuais, sua maior aplicação é na detcção de câncer de mama. Os tumores de mama têm grande angiogênese, elevando significativamente a temperatura na região, o que favorece a técnica para o diagnóstico deste tipo de tumor. (3) Existem vários estudos que investigam esta aplicação, a maioria compara a distribuição de temperatura nas duas mamas para detectar anormalidades em alguma delas. (3) Outros estudos, porém, utilizam simulação matemática, para determinar profundidade e volume da lesão à parte da alteração térmica registrada na superfície da mama. $(18,22)$

Aplicações para detecção de outros tipos de câncer vêm recentementem sendo exploradas. Chakraborty et. al. tem investigado a utilização da termografia para detecção de câncer de boca, eles encontraram uma acurácia entre 96,2\% e 97,6\% no procedimento que utiliza a região contralateral para comparação do local alterado. (23) González et. al. também tem investigado a termografia como alternativa de detecção de tumores na tireoide, este estudo se encontra em estágios iniciais e não possui resultados conclusivos. (24)

Embora a termografia seja uma técnica bastante antiga e de utilização bastante simples, atualmente ainda é muito pouco explorada. $O$ avanço recente da termografia em função do desenvolvimento tecnológico permitiu aumentar a qualidade e a sensibilidade de sensores e o desenvolvimento de métodos computacionais de processamento com microchips, o que permitiu ampliar as possibilidades da termografia como técnica diagnóstica, aumentando a resolução da detecção de imagens de infravermelho e o potencial discriminatório das imagens, além da miniaturização dos dispositivos de processamento, permitindo embuti-los em câmeras de pequeno porte.

Esse tipo de avanço tornou possível explorar a técnica, por exemplo, na dermatologia. Neste campo da medicina, existem poucos relatos da utilização de imagens de infravermelho para diagnosticar lesões malignas ou pré-malignas, que nem sempre são prontamente identificáveis ou distinguíveis entre si. Nestes casos, a 
facilidade de acesso visual destas lesões e, portanto, de coleta da radiação infravermelha emitida por elas, favorece a possibilidade de exploração desta técnica como recurso de diagnóstico, crucial nos casos de neoplasias malignas.

\subsection{Câncer de Pele}

O câncer de pele é a neoplasia de maior incidência no mundo, atingindo cerca de 115 mil novos casos ao ano, sendo 95\% destes lesões não-melanoma, cuja principal incidência é nas formas de carcinoma basocelular (CBC) e de carcinoma espinocelular (CEC). (25-26)

A exposição à radiação ultravioleta (UV) da luz solar é o principal fator de risco conhecido para o desenvolvimento de câncer de pele não-melanoma. (27-28)

O padrão ouro para o diagnóstico de várias lesões da pele é a análise clínica seguida pela dermatoscopia, que é um método para visualização das estruturas situadas abaixo do estrato córneo. Em caso de dúvida após essa avaliação, é realizada uma biópsia para exame histopatológico. (29-30)

Sabe-se que as lesões tumorais apresentam temperatura diferente em comparação com os tecidos normais, devido as suas condições metabólicas distintas, especialmente pelo aumento da vascularização para suprir o crescimento tumoral. Alguns estudos têm sido realizados na tentativa de estabelecer novos métodos de diagnóstico, tendo como alvo esta diferença de temperatura, a fim de expandir as ferramentas disponíveis para contribuir na obtenção de um diagnóstico clínico (3133)

\subsubsection{Carcinoma basocelular}

O CBC é o tipo de câncer de pele com maior incidência (aproximadamente $80 \%$ de todos os cânceres de pele não-melanoma), possui crescimento lento e raramente sofre metástase. (27,34) A mortalidade por CBC é baixa $(0,05-0,08 / 100.000$ habitantes). $\mathrm{O} C B C$ é um tumor maligno epidérmico que, na maioria das vezes, afeta 
caucasianos e tem capacidade de invasão local; as regiões do corpo mais afetadas são as áreas expostas frequentemente ao sol, tais como cabeça, pescoço e membros superiores. (34)

\subsubsection{Carcinoma espinocelular}

O CEC é a segunda neoplasia maligna de pele mais comum no mundo, e também é mais frequente em áreas do corpo mais expostas ao sol. $(28,35)$ O CEC surge da proliferação de células escamosas atípicas, tem caráter invasivo e apresenta potencial para metastatizar; a lesão primária de CEC pode surgir a partir de lesões não-invasivas, tais como queratoses actínicas (QA). (28)

\subsubsection{Melanoma}

O melanoma é uma lesão neoplásica decorrente de melanócitos epidérmicos. É um câncer altamente invasivo e agressivo, com alta taxa de mortalidade. Pessoas com pele clara e que tiveram intensa exposição à luz solar têm maior probabilidade de desenvolver a doença. (36) O melanoma metastático normalmente leva à morte; ainda assim, muitas pessoas podem ser curadas na fase inicial da doença. Isso mostra que é muito importante o desenvolvimento de estratégias eficazes para o diagnóstico precoce. (37)

\subsubsection{Diagnóstico de lesões clinicamente semelhantes}

Uma das grandes dificuldades em diagnosticar estas lesões é que elas muitas vezes podem ser clinicamente semelhantes a outras lesões, sejam elas malignas, prémalignas ou benignas. Isso significa que uma lesão benigna pode ter o mesmo aspecto, sob inspeção visual, de uma lesão maligna e vice-versa, e o diagnóstico errado pode levar a complicações no tratamento dessas lesões. Neste estudo, são 
reportados três pares de lesões clinicamente semelhantes, nos quais uma das lesões é maligna e a outra não:

- O nevo intradérmico é um tipo benigno de lesão da pele, mas que, muitas vezes, ao ser analisado por um médico não especialista, pode ser clinicamente semelhante a uma lesão do tipo CBC nodular (Figura 2).

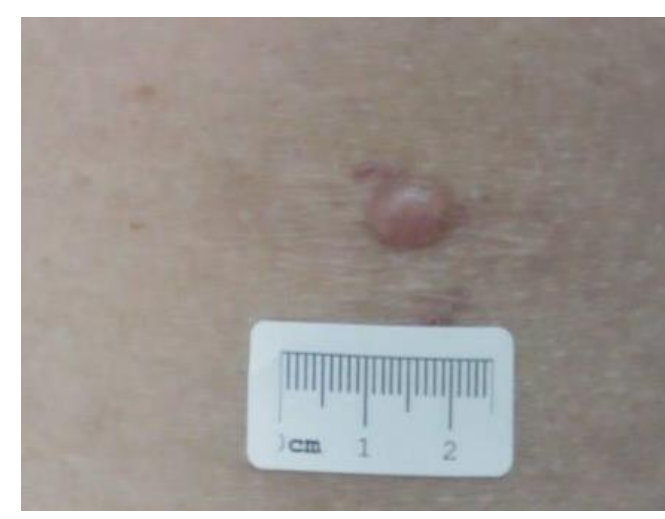

(A)

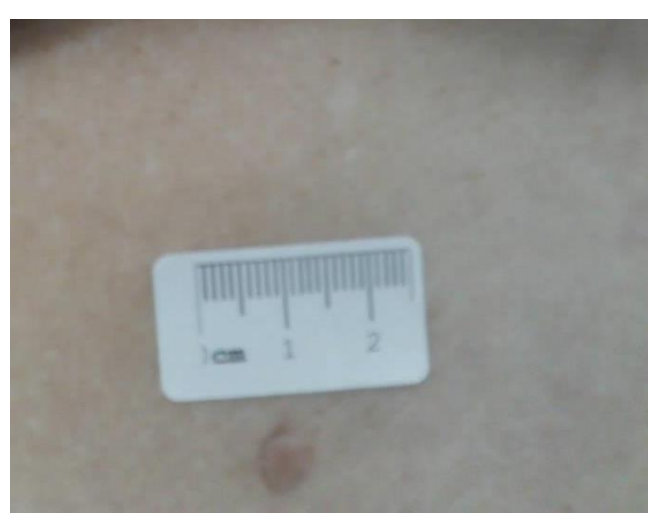

(B)

Figura 2 - (A) Imagem de uma lesão de CBC e (B) Imagem de um nevo intradérmico. Fonte: Elaborada pela autora.

- A QA é uma lesão pré-maligna e sua aparência clínica mais comum é avermelhada, escamosa e geralmente incide em uma área exposta ao sol. $(38,39) \mathrm{A}$ evolução de uma QA para um CEC pode acontecer de maneira contínua e progressiva, de forma a ser difícil saber em seu diagnóstico o momento exato em que se torna maligna (Figura 3). (38) 


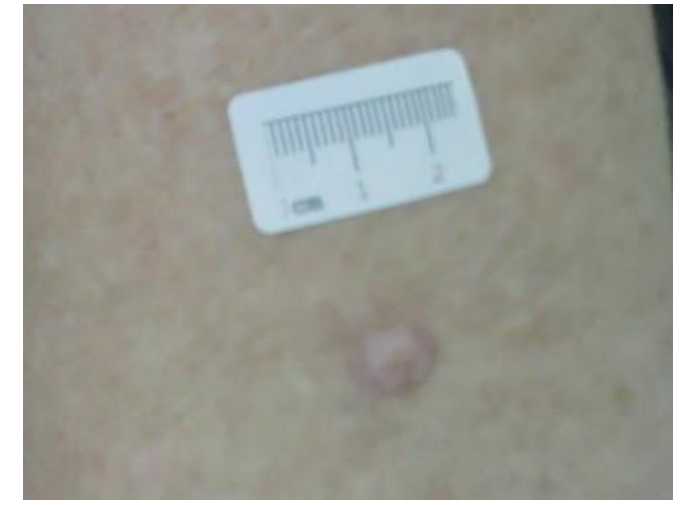

(A)

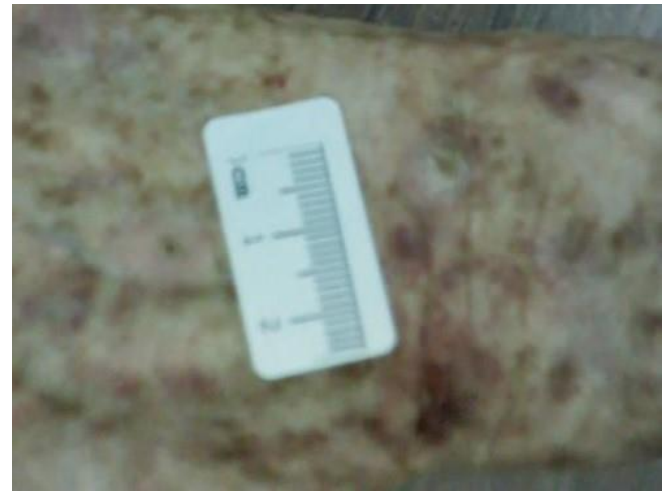

(B)

Figura 3 - (A) Imagem de CEC e (B) Imagem de QA. Fonte: Elaborada pela autora.

- A queratose seborreica pigmenta (QSP) é um tumor benigno, mas que muitas vezes pode ser clinicamente semelhante a um melanoma, que é maligno, tornando necessária uma biópsia excisional para concluir um diagnóstico definitivo (Figura 4). (29)

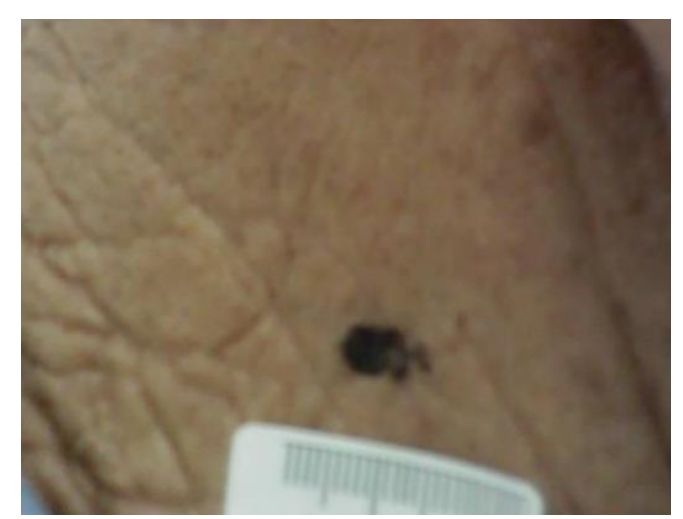

(A)

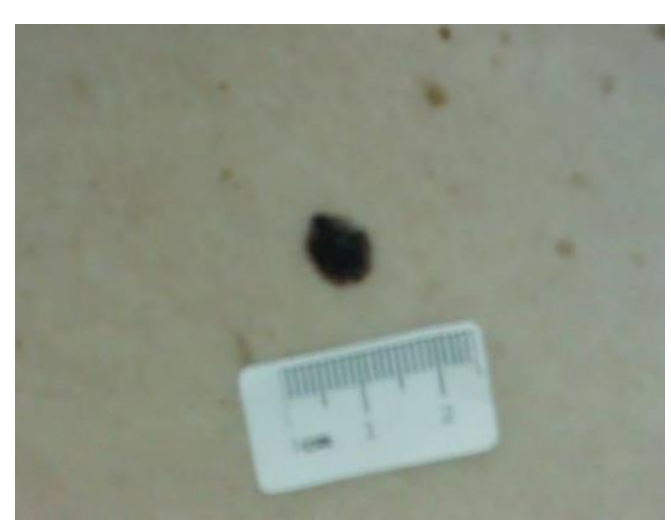

(B)

Figura 4 - (A) Imagem de lesão de melanoma e (B) imagem de uma QSP. Fonte: Elaborada pela autora.

Existem estudos de dermatologia na literatura que sugerem que a alta temperatura pode ser observada em tumores agressivos, tais como melanoma; (13) outros estudos utilizam o resfriamento de lesões e verificam a diferença do tempo de recuperação da temperatura para distinguir lesões de pele benignas, malignas e tecido normal. (40-41) No entanto, nenhum estudo mostra alterações de temperatura na 
região destas lesões de uma forma quantitativa, permitindo a discriminação destes tumores com relação a lesões clinicamente semelhantes.

\subsection{Terapia Fotodinâmica}

A Terapia Fotodinâmica (TFD) é uma modalidade terapêutica alternativa para o tratamento de lesões malignas e potencialmente malignizáveis. A TFD utiliza três elementos-chave: um fotossensibilizador (FS), a luz no comprimento de onda adequado e o oxigênio presente na célula. O FS é administrado localmente ou sistemicamente e depois de um intervalo de tempo em que ocorre a biodistribuição, o FS terá se acumulado preferencialmente no tecido tumoral, e o local é então iluminado com luz de comprimento de onda apropriado. A absorção da luz pelo FS inicia reações fotoquímicas que geram produtos citotóxicos (espécies reativas de oxigênio), que por sua vez levam as células tumorais à morte. (42) Deste modo, a interação FS, luz e oxigênio molecular que está presente no tecido resulta em espécies reativas de oxigênio capazes de levar as células tumorais à morte. (43)

Quando as moléculas de FS recebem luz com energia apropriada, elétrons são excitado do estado fundamental para estados de maior energia. Então, os elétrons podem voltar para o estado fundamental por fluorescência ou por decaimentos não radioativos, que por vibração das moléculas é gerado calor, ou pode decair para um estado tripleto intermediário metaestável, através do chamado cruzamento intersistema, como se verifica no Diagrama de Jablonski da Figura 5. O tempo desse estado intermediário metaestável varia de $10^{-3}$ a 10 segundos e, durante esse tempo, o FS excitado pode interagir com moléculas vizinhas através de dois mecanismos: $1^{\circ}$ ) pode remover um átomo de hidrogênio de uma molécula ou transferir elétrons, gerando radicais livres que são capazes de oxidar uma grande quantidade de moléculas (as chamadas reações tipo I); ou $2^{\circ}$ ) pode transferir energia ao oxigênio molecular inicialmente no estado fundamental (tripleto) para excitá-lo para um estado singleto metaestável, que é uma forma altamente reativa de oxigênio, sendo mediador de dano fotoquímico na célula. Tais interações podem resultar na destruição do sistema vascular ou da matriz intercelular ou, ainda, na modificação de funções 
mitocondriais e de sistemas de biomembranas celulares, em que ambos levam à morte as células neoplásticas, preferencialmente. (44)

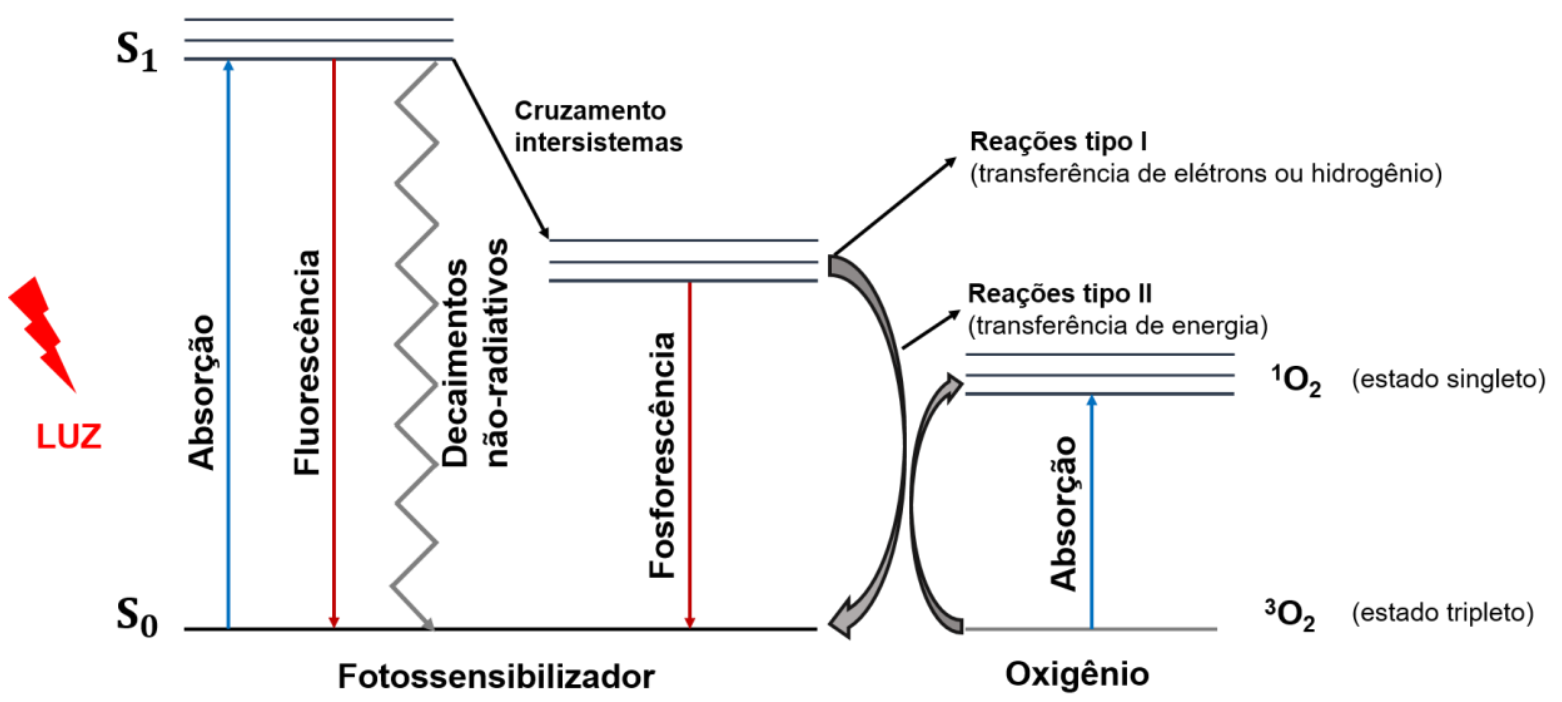

Figura 5 - Diagrama de Jablonski simplificado Fonte: Adaptada de LANGER. (45)

A qualidade de um fotossensibilizador pode ser determinada pela sua eficiência em sofrer cruzamento intersistema: quanto maior é essa eficiência, melhor é considerado o FS. (44) Esta eficiência também pode ser determinada por outros aspectos como a seletividade e toxicidade da droga. (46)

O ácido aminolevulínico (ALA) e o aminolevulinato de metila (Metil-ALA), são precursores da protoporfirina IX (PpIX), um fotossensibilizador endógeno presente em pequenas quantidades nas células. Após este precursor penetrar na célula, ele interage na biossíntese do grupo heme e estimula maior formação de PpIX que se acumula preferencialmente em tecidos alterados, por razões que ainda não são completamente compreendidas: alterações na membrana das células anormais ou imaturidade das fibras de colágeno constituintes da lesão são as causas mais prováveis. (47-48) 


\subsubsection{Interação da luz com o tecido}

Quando a luz incide sobre um material, ela pode ser refletida na superfície ou penetrar no mesmo, se o material for completamente transparente, o feixe sofrerá um desvio na direção de propagação (refração) segundo a Lei de Snell $\left(n_{1} \operatorname{sen} \theta_{1}=\right.$ $n_{2} \operatorname{sen} \theta_{2}$ ) e sairá pela outra face do material (feixe transmitido) sofrendo outra refração, onde $\mathrm{n}_{1}$ e $\mathrm{n}_{2}$ são os índices de refração nos meios 1 e 2 , respectivamente, $\theta_{1}$ é o ângulo de incidência e $\theta_{2} \circ$ ângulo refratado. Porém, se o meio não for transparente, o feixe sofrerá uma atenuação de intensidade, através de dois processos: a absorção e o espalhamento. (49)

Quando ocorre o fenômeno da absorção, uma das possíveis formas desta energia luminosa depositada sobre o material ser convertida é a energia térmica ou calor. Podemos estimar a quantidade de energia luminosa que foi convertida em calor, após ser absorvida por um tecido, pela equação (3), sendo $E[\mathrm{~J}]$ a energia convertida em calor, $m[\mathrm{~kg}]$ massa do tecido, $c\left[\mathrm{~J} / \mathrm{kg} .{ }^{\circ} \mathrm{C}\right.$ ] o calor específico do tecido e $\Delta T\left[{ }^{\circ} \mathrm{C}\right]$ a variação da temperatura na região.

$$
E=m c \Delta T
$$

\subsubsection{Evidenciação da fluorescência}

Algumas moléculas constituintes da pele como colágeno, elastina, queratina e nicotinamida adenina dinucleotídeo (NADH) são denominados fluoróforos endógenos, tipo de cromóforo que absorve a luz em comprimento de onda adequado e pode emitir fluorescência, estes são responsáveis pela autofluorescência da pele. A concentração destes fluoróforos na pele pode ser alterada quando a pele sofre algum tipo de modificação, de modo que a emissão de fluorescência pela pele também será modificada, assim, lesões de pele podem ser evidenciadas ou até mesmo diagnosticadas por técnicas de fluorescência. (50)

A PpIX tem propriedades de fluorescência características e seu acumulo preferencial em tecidos alterados favorecem o uso da técnica como ferramenta de diagnóstico. (47-48) As regiões com maior acumulo de PpIX apresentam intensa 
fluorescência induzida, enquanto que em regiões com menor acúmulo esta fluorescência é bem menos detectável. Para evidenciação desta "fluorescência marcada" é possível excitar o tecido com luz na região do azul, onde a PpIX apresenta uma fluorescência vermelha intensa que contrasta com a autofluorescência verde intrínseca da pele. (51)

\subsubsection{Importância da discriminação clínica de lesões}

A TDF tem sido indicada cada vez mais para o tratamento de CBC e de lesões pré-malignas, como as QA. Nos casos de CEC e melanoma, porém, tem sido contraindicada dada a agressividade e o potencial de metastatização destas lesões. Por isso, considerada a dificuldade da diferenciação clínica entre pares de lesões para as quais a TFD é indicada ou contra-indicada (como é o caso das QA e CEC, respectivamente), é necessário encontrar ferramentas que possam auxiliar 0 diagnóstico clínico, buscando garantir a indicação adequada do tratamento e, portanto, a eliminação completa da lesão. Neste sentido, a análise de imagens de infravermelho apresenta potencial relevante na diferenciação clínica destas lesões, uma vez que, neste caso, se propõe diferenciar lesões malignas e não-malignas, cujas características metabólicas são conhecidamente diferentes. 


\section{OBJETIVOS}

\section{Objetivos principais}

- Este trabalho tem como objetivos principais: (1) avaliar o uso da termografia para discriminar pares de lesões cutâneas clinicamente semelhantes; (2) monitorar termicamente a resposta de lesões do tipo CBC à Terapia Fotodinâmica a fim de compreender o comportamento térmico destas lesões durante $o$ tratamento, buscando revelar uma relação entre assinatura térmica e evidências de fatores como resposta inflamatória do tecido e formação de necrose.

\section{Objetivos secundários}

1. Validar o uso da termografia em modelo tumoral in vivo para identificar e acompanhar o crescimento tumoral;

2. Avaliar os padrões térmicos dos diferentes tipos de lesões cutâneas selecionados para este estudo;

3. Identificar as fontes de variações de temperatura que ocorrem na pele durante a Terapia Fotodinâmica

4. Elaborar um modelo simples que seja capaz de estimar as quantidades de energia luminosa convertidas em efeito térmico e fotodinâmico. 


\section{MATERIAIS E MÉTODOS}

Este estudo foi dividido em duas partes, sendo a primeira um estudo in vivo (prova de princípio com animais) e a segunda um estudo clínico (diferenciação de lesões clinicamente semelhantes e monitoramento da terapia fotodinâmica).

\subsection{Aquisição da Imagem}

As imagens de infravermelho foram coletadas através do termovisor FLK-Ti400 (Fluke®, Everett, EUA), Figura 6, com lente infravermelha padrão (campo de visão de $24^{\circ} \times 17^{\circ}$, resolução espacial (IFOV) de $1,31 \mathrm{mRad}$ e distância mínima do foco de 15 $\mathrm{cm}$ ) para coletar comprimentos de onda entre 7,5 e $14 \mu \mathrm{m}$ do infravermelho longo, tem sensibilidade térmica $\leq 0,05^{\circ} \mathrm{C}$, precisão de $\pm 2{ }^{\circ} \mathrm{C}$ e resolução $320 \times 240$ pixels. Seu detector é do tipo microbolômetro não refrigerado (Anexo A). (52)

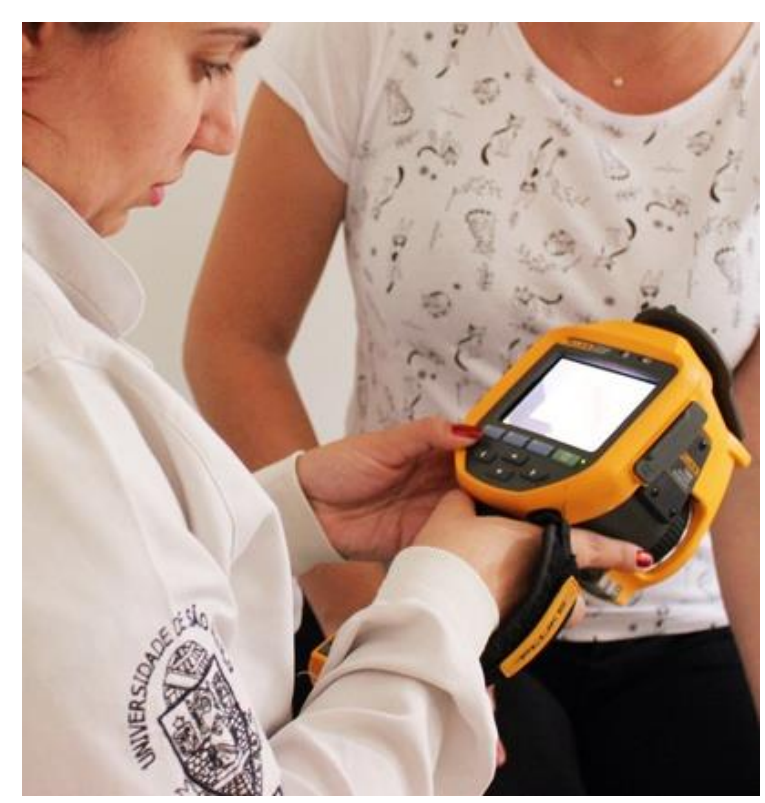

Figura 6 - Termovisor utilizado. Fonte: Elaborada pela autora

O termovisor possui a vantagem de mostrar a imagem térmica em seu visor, sem a necessidade de conectar a um computador para visualizá-la. Além disso, em 
paralelo à imagem infravermelha, o equipamento utilizado também permite a coleta da imagem de luz visível do mesmo sítio anatômico, utilizada para identificação da região investigada e correlação com a termografia. A imagem de luz visível é registrada com campo maior e levemente deslocada com relação a imagem registrada pelo detector de infravermelho.

O equipamento é calibrado pelo fabricante e possui ainda opções de ajuste de foco automático ou manual, legenda das cores correspondente às temperaturas em tempo real e a opção de usar marcadores que permitem monitorar em tempo real a temperatura em locais específicos. As imagens salvas pelo termovisor também podem ser transferidas para um computador e, através de seu software Fluke SmartView® 3.5, é possível gerar arquivos adequados para visualização processamento da informação coletada, tanto para as imagens de luz branca quanto para as termografias, neste último caso, o arquivo consiste de uma matriz onde cada posição (pixel) corresponde a um valor de temperatura.

\subsection{Modelo animal}

\subsubsection{Anestesia e climatização do ambiente}

Os procedimentos em animais descritos tiveram aprovação pela Comissão de Ética para Uso de Animais do Instituto de Física de São Carlos (Protocolo no 04/2014 - Anexo B).

Os animais foram anestesiados utilizando um sistema de anestesia inalatória com uso de máscara e isoflurano ( $2 \%$ em oxigênio).

Antes de cada procedimento 0 animal permanecia na sala por cerca de 20 minutos com temperatura fixada em $23^{\circ} \mathrm{C}$. 


\subsubsection{Indução do tumor}

Foi utilizado o modelo de tumor de Ehrlich, que é um derivado de câncer de mama modificado para desenvolvimento murinho. Possui a vantagem de ter cultivo simples através de injeção das células em forma fluida, chamada ascética. Esse fluido pode ser injetado no peritônio de um camundongo saudável, para o desenvolvimento da forma ascítica do tumor, ou no tecido subcutâneo, para desenvolvimento da forma sólida do tumor. (53)

Foram injetados $300 \mu \mathrm{L}$ da forma fluida de uma solução estoque no peritônio de um camundongo Swiss, resultando cerca de $5 \mathrm{~mL}$ de uma cultura celular após um período de 10 dias. Dessa solução, foi possível realizar a indução dos tumores sólidos, e o restante da solução foi utilizada para a reposição do estoque. Para isto, foi acrescentado glicerol $40 \%$ à solução, que passou a ser mantida em freezer a $-20^{\circ} \mathrm{C}$ por 3 horas, com subsequente transferência para o nitrogênio líquido.

Para a obtenção de tumores sólidos, foram utilizados 9 camundongos Swiss, com 6 semanas de idade. Os animais foram anestesiados, tricotomizados e foram injetadas subcutaneamente células de tumor de Ehrlich ( $10^{6}$ células em $100 \mu \mathrm{L}$ ) no dorso dos animais. $\mathrm{O}$ crescimento do tumor foi acompanhado através da coleta de imagens de infravermelho e de medidas do diâmetro do tumor utilizando um paquímetro. $\mathrm{O}$ monitoramento do crescimento foi realizado até que a lesão atingisse cerca de $1 \mathrm{~cm}$ de diâmetro. Para estes procedimentos não foi necessário anestesiar os animais, apenas contenção manual.

\subsubsection{Terapia Fotodinâmica}

Outros 6 animais foram utilizados para a realização de TFD no tecido sadio. Estes foram divididos em dois grupos de 3 animais. Todos os animais foram anestesiados e tricotomizados. No Grupo 1 foi realizada a iluminação do tecido-alvo sem a presença do FS, com o intuito de monitorar o aquecimento gerado exlusivamente pela luz. Esta iluminação foi feita com o equipamento LINCE $^{\circledR}$ (LINCE, MMOptics, São Carlos - SP, Brasil) utilizando a ponteira de tratamento cujo 
comprimento de onda é de $630 \mathrm{~nm}$, com intensidade $125 \mathrm{~mW} / \mathrm{cm}^{2}$ durante $20 \mathrm{~min}$, totalizando uma dose de $150 \mathrm{~J} / \mathrm{cm}^{2}$. Imagens térmicas foram registradas a cada 2 minutos no período de iluminação e a cada 1 minuto no período pós até que a temperatura do tecido retornasse ao normal. No mesmo tecido, foi aplicado o creme contendo 20\% Metil-ALA (PDT Pharma, Cravinhos - SP, Brasil) e após o tempo de incubação de 3 horas, para que haja adsorção do FS pela lesão, foi realizada novamente a mesma iluminação, sendo que desta vez tem-se a realização da TFD.

No Grupo 2 foi realizada foi realizada uma curetagem numa região de cerca de $1 \mathrm{~cm}$ de diâmetro para simular uma lesão e o mesmo procedimento do grupo 1 foi realizado.

\subsubsection{Morte dos animais}

Após o tumor atingir $1 \mathrm{~cm}$ de diâmetro ou após passar pelo procedimento de TFD, o animal foi morto por overdose de isoflurano sob plano anestésico, com posterior perfuração do diafragma previamente ao descarte.

\subsection{Estudo Clínico}

O estudo clínico foi desenvolvido no Departamento de Pele da Fundação Hospital Amaral Carvalho em Jahu-SP, em colaboração com a médica dermatologista Profa. Dra. Ana Gabriela Sálvio. Foram coletadas imagens térmicas das lesões em duas situações distintas ao longo do estudo: durante o diagnóstico das lesões e na avaliação da resposta à TFD. Este estudo teve aprovação do Comitê de Ética em Pesquisa Fundação Hospital Amaral Carvalho (Parecer no 1.171.682 - Anexo C).

Os pacientes foram orientados sobre $\mathrm{o}$ uso das imagens em pesquisa $\mathrm{e}$ aceitaram voluntariamente fazer parte do estudo, com preservação de sua identidade. Todos os voluntários da pesquisa assinaram um Termo de Consentimento Livre e Esclarecido (Anexo D). 
Cada paciente permaneceu em uma sala com temperatura em torno de $23{ }^{\circ} \mathrm{C}$ durante um tempo médio de 20 min entre o acolhimento e o momento em que a termografia foi realizada. E, em cada paciente foi colado um adesivo com escala milimétrica próximo à lesão para, que em cada imagem fosse possível padronizar o tamanho correspondente aos pixels.

Ao voluntário, que é submetido exclusivamente à aquisição de imagens térmicas, não é oferecido nenhum tipo de risco decorrente deste estudo, uma vez que a câmera utilizada apenas registra a radiação infravermelha emitida naturalmente pelo próprio corpo. Além disso, este estudo não interfere na conduta médica durante o atendimento, procedimento diagnóstico ou tratamento do paciente; as imagens foram analisadas posteriormente e comparadas com o diagnóstico dado pelo dermatologista e pela análise histopatológica e, então, arquivadas em um banco de dados pelo pesquisador responsável, de acordo com os critérios estabelecidos no parecer do Comitê de Ética.

\subsubsection{Discriminação de lesões clinicamente semelhantes}

Foram realizadas imagens de seis diferentes tipos de lesões de pele através da câmera de infravermelho. Um total de 310 lesões cutâneas foram registradas, e avaliadas em relação à diferença de temperatura da lesão quando comparada ao tecido sadio. O número de lesões registradas para cada tipo é apresentado a seguir:

- 100 lesões do tipo CBC;

- 100 lesões do tipo nevo intradérmico;

- 35 lesões do tipo QA;

- 35 lesões do tipo CEC;

- 20 lesões do tipo queratose seborreica pigmentada;

- 20 lesões do tipo melanoma.

O total de lesões registradas foi menor para os tipos melanoma, queratose seborreica pigmentada, CEC e QA devido à mais baixa incidência das lesões de melanoma e CEC. Portanto, seus respectivos pares foram mantidos com número de lesões semelhante para uma comparação mais fidedigna dos resultados. 
As lesões do tipo CBC, por serem bastante incidentes, foram selecionadas de forma com que apenas as nodulares não ulceradas e sem pigmentos fossem incluídas neste estudo. As lesões do tipo melanoma, por ser pouco incidente, não houve possibilidade de seleção, foram coletadas 13 lesões extensas e 7 nodulares.

A definição do procedimento diagnóstico foi realizada pelos critérios definidos pela dermatologista responsável, dentro da rotina clínica do Departamento de Pele e Tecidos Moles. Para as lesões dos tipos CBC, CEC e melanoma, foram utilizados os resultados de exame histopatológico obtido por biopsias das lesões, retiradas cirurgicamente. Já para as lesões dos tipos QA, nevo intradérmico e queratose seborreica pigmentada, análises clínicas e dermatoscópicas feitas pela dermatologista no ambulatório foram utilizadas para classificá-las.

\subsubsection{Monitoramento da TFD}

As lesões avaliadas nesta etapa do estudo estão sendo tratadas dentro de um projeto clínico, denominado "Terapia Fotodinâmica Brasil", com aprovação no 140/11 do Comitê de Ética em Pesquisa da Fundação Hospital Amaral Carvalho. Nele já estão sendo tratadas lesões de CBC com TFD, por meio de diferentes protocolos: os CBC tratados pelo projeto são sempre superficiais com no máximo $2 \mathrm{~cm}$ de diâmetro ou nodulares com infiltração máxima de $3 \mathrm{~mm}$ de profundidade. (54) Estas lesões são inicialmente curetadas (o material curetado é enviado para biópsia) previamente à aplicação do creme contendo 20\% Metil-ALA (PDT Pharma, Cravinhos - SP, Brasil). Após o tempo de incubação de 3 horas para que formação do FS endógeno pela lesão, é realizada iluminação com o equipamento LINCE ${ }^{\circledR}$ (LINCE, MMOptics, São Carlos - SP, Brasil) utilizando a ponteira de tratamento cujo comprimento de onda é de $630 \mathrm{~nm}$, com intensidade $125 \mathrm{~mW} / \mathrm{cm}^{2}$ durante $20 \mathrm{~min}$, totalizando uma dose de $150 \mathrm{~J} / \mathrm{cm}^{2}$. Uma segunda sessão, idêntica em procedimentos (exceto pela curetagem), é repetida após sete dias.

Em 40 lesões do tipo CBC (23 nodulares e 17 superficiais), foram coletadas imagens com câmera de infravermelho em diferentes fases durante as duas sessões do tratamento: lesão inicial, após o tempo de incubação do medicamento e imediatamente após a iluminação. 
A fim de observar a alteração térmica do tecido provocada apenas pela luz, o mesmo protocolo de iluminação foi realizado em tecido sadio, sem administração prévia do Metil-ALA, em 3 voluntários, com comprimento de onda de $630 \mathrm{~nm}$ e intensidade $125 \mathrm{~mW} / \mathrm{cm}^{2}$ durante $20 \mathrm{~min}$, totalizando uma dose de $150 \mathrm{~J} / \mathrm{cm}^{2}$. Nestes voluntários foi realizada a coleta de imagens térmicas antes, durante e imediatamente após a iluminação. Para as medidas durante a iluminação, esta era interrompida por cerca de 30 segundos a cada 2 minutos para a aquisição do termograma. Para monitorar o resfriamento da região, o mesmo voluntário recebeu a dose de luz de maneira ininterrupta e as medidas térmicas foram realizadas a cada 3 minutos durante 21 minutos.

Além disso, também foram realizadas imagens de fluorescência da lesão utilizando a ponteira de evidenciação de fluorescência do equipamento LINCE, com excitação centrada em $400 \mathrm{~nm}$ e com potência de saída de $50 \mathrm{~mW} / \mathrm{cm}^{2}$. As imagens de fluorescência foram registradas nas mesmas fases do tratamento: lesão inicial, após o tempo de incubação do medicamento e imediatamente após a iluminação.

Estes pacientes retornaram ao ambulatório após 30 dias para avaliar a eficácia do tratamento, incluindo coleta de biópsia para avaliação histopatológica.

O procedimento completo para aquisição de cada imagem utilizando a câmera de infravermelho (posicionamento, ajuste de foco etc) é de aproximadamente $30 \mathrm{~s}$.

Com as análises das imagens, estimada a quantidade de energia entregue ao tecido que de fato foi utilizada no procedimento da TFD.

\subsection{Processamento de imagens}

As imagens coletadas pelo termovisor foram armazenadas em um banco de dados e o padrão de temperatura da lesão inicial e durante 0 tratamento foram analisados qualitativamente (como maior ou menor em relação ao do tecido sadio correspondente). 


\subsubsection{Análise da média de temperaturas}

Foi elaborada uma rotina utilizando o software MATLAB® 7.8 (R2009a), que permite calcular as temperaturas médias e seus desvios padrão na área da lesão e no tecido sadio ao seu redor, através da informação dada por cada pixel da imagem. Com essa rotina, é possível delimitar manualmente uma região para a qual se tenha interesse de calcular a média de temperatura, e uma segunda região ao seu redor, descontando ou não a região interior delimitada anteriormente (Figura 7).

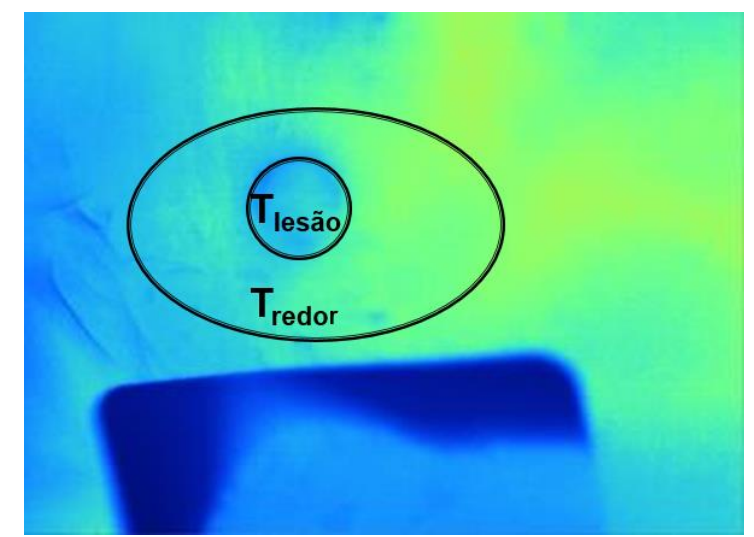

Figura 7 - Exemplo de áreas delimitadas na área da lesão e no tecido sadio ao redor utilizando a rotina elaborada em MATLAB®.

Fonte: Elaborada pela autora.

Esta rotina de processamento foi utilizada para todas as imagens termográficas obtidas nesse estudo, tanto in vivo quanto nos testes clínicos.

O comportamento da temperatura cutânea na lesão, bordas e redondezas foi avaliado, bem como a transição de temperatura em cada uma dessas regiões.

Foram realizados gráficos de temperatura e de suas temperaturas em função dos pixels da imagem quando tracejada uma linha que atravessa o centro da lesão na tentativa de discriminação das lesões clinicamente semelhantes.

4.4.2 Análise dos atributos das imagens

Para discriminação mais eficiente entre os pares de lesões clinicamente semelhantes, foram realizadas técnicas de processamento e análise de imagens. Foi 
elaborada uma nova rotina no software MATLAB®, e posteriores análises foram realizadas no software Weka® 3.8 (1999-2016, The University of Waikato, New Zealand).

Inicialmente, as imagens foram cortadas manualmente. Cada imagem foi cortada incluindo apenas a própria lesão e uma margem de aproximadamente $2 \mathrm{~mm}$ da borda. Em algumas das lesões pode ser identificada a presença de pelos e irregularidade da superfície da pele que podem interferir nas análises. Estes "artefatos" são inerentes à pele e, portanto, quaisquer discriminações realizadas devem ser factíveis apesar de sua presença.

Uma seleção de atributos foi feita com base nas características das imagens das lesões. Esses atributos foram explorados para contribuir para a discriminação das classes.

Diversos atributos foram testados, de forma que o conjunto de atributos que apresentou melhor resultado está apresentado na Tabela 2. Assumindo Ti como o valor da temperatura de cada pixel de uma imagem, os seguintes conjuntos de características foram avaliados: atributos estatísticos, análises do histograma e interface lesão-tecido..

"Atributos estatísticos" representam a análise estatística dos valores de temperatura para cada imagem, utilizando como atributos onze parâmetros estatísticos: entropy, subtração maximum-minimum ("máximo menos mínimo"), mean, standard deviation, variation coefficient, skewness, kurt, contrast, correlation, energy e homogeneity. (55-57) "Análise de histograma" baseia-se nos valores do histograma de temperatura de cada imagem. Cada histograma de imagem foi ajustado por uma equação polinomial de segunda ordem, já que o histograma melhor se ajustava a uma parábola. Os coeficientes da equação obtidos foram utilizados como atributos. "Interface lesão-tecido" representa filtros que foram utilizados para selecionar apenas a região da lesão e para diferenciar esta região da pele saudável. Os filtros escolhidos para esta análise são segmentações Otsu e Weight e filtros Prewitt e Roberts. (5557) Os atributos de comparação utilizaram as temperaturas médias dentro e fora das bordas da lesão, com as bordas identificadas pelos diferentes filtros. Todos os atributos são mostrados e descritos na Tabela 2. 
Tabela 2 - Métricas usadas na rotina elaborada em MATLAB ${ }^{\circledR}$

\begin{tabular}{|c|c|c|}
\hline $\begin{array}{l}\text { Função } \\
\text { MATLAB }^{\circledR}\end{array}$ & Expressão definida pela função & $\begin{array}{l}\text { Informação representada pela } \\
\text { função }\end{array}$ \\
\hline \multicolumn{3}{|c|}{ Atributos estatísticos } \\
\hline entropy & $H=\sum_{i} p_{i} \cdot \log \left(p_{i}\right)^{*}$ & Grau de desordem da imagem \\
\hline $\begin{array}{l}\text { maximum } \\
\text { minus } \\
\text { minimum }\end{array}$ & $T_{\max }-T_{\min }$ & $\begin{array}{c}\text { Diferença entre valores máximos e } \\
\text { mínimos de temperatura }\end{array}$ \\
\hline Mean & $\bar{T}=\frac{1}{N} \sum_{i=1}^{N} T_{i}$ & Média dos $\mathrm{N}$ pixels de temperatura \\
\hline Std & $\sigma_{T}=\sqrt{\frac{\sum_{i}^{N}\left(T_{i}-\bar{T}\right)^{2}}{N-1}}$ & Desvio padrão de temperatura \\
\hline $\mathrm{Cv}$ & $c v=\frac{\sigma_{T}}{\bar{T}}$ & Coeficiente de variação \\
\hline Skewness & $S=\frac{E\left(T_{i}-\bar{T}\right)^{3}}{\sigma_{T}^{3}} \star \star$ & $\begin{array}{c}\text { Assimetria da distribuição de } \\
\text { temperatura }\end{array}$ \\
\hline Kurt & $k=\frac{E\left(T_{i}-\bar{T}\right)^{4}}{\sigma_{T}^{4}}$ & $\begin{array}{l}\text { Assimetria da distribuição de } \\
\text { temperatura }\end{array}$ \\
\hline $\begin{array}{l}\text { Contrast } \\
\text { Correlation }\end{array}$ & $\begin{array}{c}\sum_{i} \sum_{j}(i-j)^{2} \cdot \operatorname{glcm}(i, j)^{* * *} \\
\frac{\sum_{i} \sum_{j}(i-\bar{l})(j-\bar{j}) \operatorname{glcm}(i, j)}{\sigma_{\cdot} \sigma_{\dot{*}}}\end{array}$ & \\
\hline Energy & $\sum_{i} \sum_{i} \operatorname{glcm}(i, j)^{2}$ & \\
\hline Homogeneity & $\frac{\sum_{i} \sum_{j} \operatorname{glcm}(i, j)}{1+|i-j|}$ & \\
\hline
\end{tabular}

Análises do histograma

$\begin{array}{ccc}\text { zcoef1 } & \mathrm{h}(\mathrm{T})=\begin{array}{c}\text { zcoef1 } 1 \mathrm{~T}^{2}+\text { zcoef2.T } \\ \text { zcoef2 }\end{array} & \text { Regressão polinomial do histograma } \\ \text { zcoef3 } & \text { zcoef3 } & - \text { grau } 2\end{array}$

zcoef3

$\mathrm{h}(\mathrm{T})=$ coef1. $\mathrm{T}^{2}+$ coef $2 . \mathrm{T}+$ coef3

Regressão polinomial do histograma - grau 2

coef2

\section{Interface de lesões cutâneas}

\section{DenFor1}

Média de temperatura dentro dividida pela média de temperatura ao redor da lesão (segmentação Otsu)

Média de temperatura da borda

DenFor2 dividida pela temperatura ao redor (filtro 'prewitt')

Média de temperatura da borda

DenFor3 dividida pela temperatura ao redor (filtro 'roberts')

Média de temperatura dentro dividida

DenFor4 pela média de temperatura ao redor da lesão (segmentação Weight Pixel)

Edge1 Média de temperatura da borda (filtro 'prewitt')

Edge2

Média de temperatura da borda (filtro 'roberts')

${ }^{*} p$ (i) é histograma normalizado da imagem (58)

${ }^{* *} E(t)$ representa o valor esperado da variável $t(58)$

*** $i$ e $j$ representam as dimensões de linhas e colunas da imagem, e glcm(i, j) representa a matriz de co-ocorrência dos níveis de cinza (58)

Fonte: Elaborada pela autora. 
Da mesma forma que realizamos os testes de conjunto de atributos, também foram testados classificadores usando o software Weka ${ }^{\circledR}$. Dos classificadores testados, a Máquina Vetorial de Suporte (MVS) foi a que apresentou melhor índice de discriminação e, então, foi adotada como classificador para discriminar os valores das métricas das lesões. O MVS é um método de classificação binário, ele toma os dados de duas classes como entrada e armazena estes dados em arquivos modelos. A intenção é ordenar novos dados coletados em uma das duas classes.

O MVS procura uma linha de separação entre os dados das duas classes, esta linha é comumente chamada de hiperplano. Posteriormente, busca-se a maximização da distância entre o hiperplano e o primeiro ponto de cada classe (distância chamada de margem). (59-61)

O uso de MVS envolve duas etapas básicas: treinamento e teste. $O$ treinamento envolve a alimentação de dados conhecidos e, a partir deste conjunto de informações, é possível classificar os dados. O MVS é uma técnica de aprendizado mecânico, que se origina da teoria estatística e tem sido amplamente utilizada em aplicações de reconhecimento de padrões devido à sua eficiência computacional e bom desempenho. A principal vantagem do MVS é a capacidade de modelar sistemas altamente não-lineares e obter bom resultado de separação entre eles a partir das propriedades de superfície. (59-61)

De modo geral, as etapas realizadas neste estudo até que se fosse obtido o melhor método de discriminação das lesões clinicamente semelhantes estão apresentadas no fluxograma da Figura 8. 


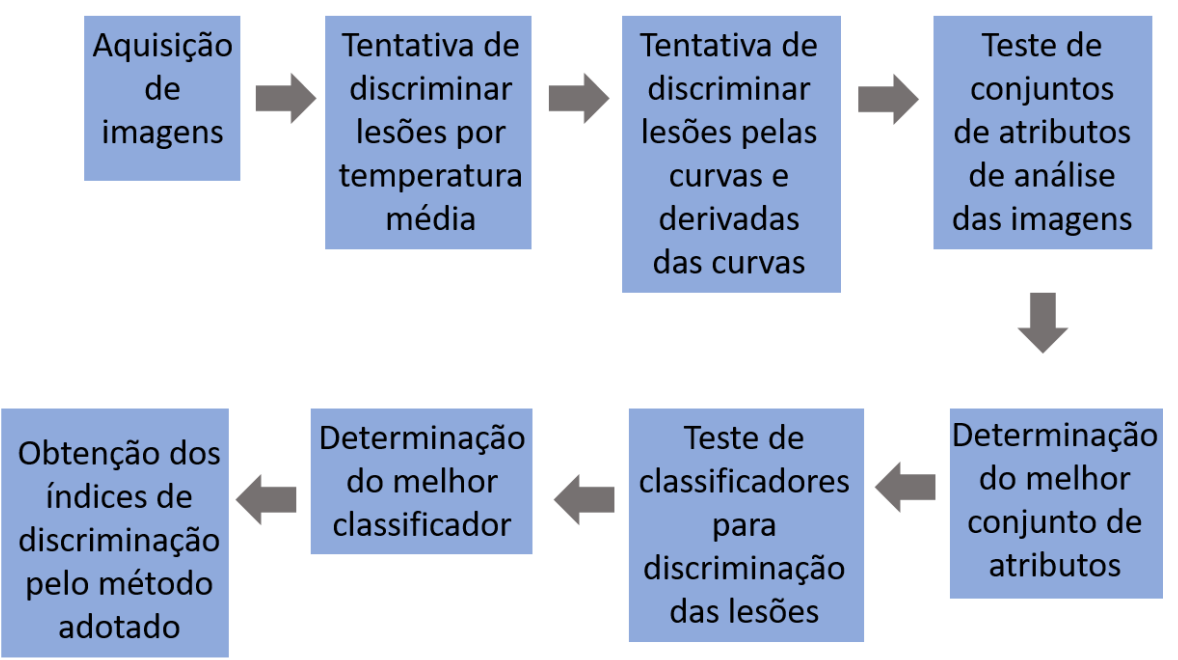

Figura 8 - Fluxograma das etapas de análises e determinação de método de discriminação das imagens das lesões clinicamente semelhantes.

Fonte: Elaborada pela autora. 


\section{RESULTADOS E DISCUSSÃO}

\subsection{Modelo Animal}

\subsubsection{Monitoramento do crescimento tumoral}

Para validar o uso do termovisor na identificação de lesões tumorais, foi realizado um estudo em modelo animal.

O crescimento do tumor de Ehrlich obtido da injeção subcutânea foi acompanhado, através de imagens de infravermelho, até que a lesão atingisse tamanho de $1 \mathrm{~cm}$ de diâmetro. A Figura 9 mostra o crescimento típico do tumor na região tricotomizada do animal a partir de imagens termográficas.

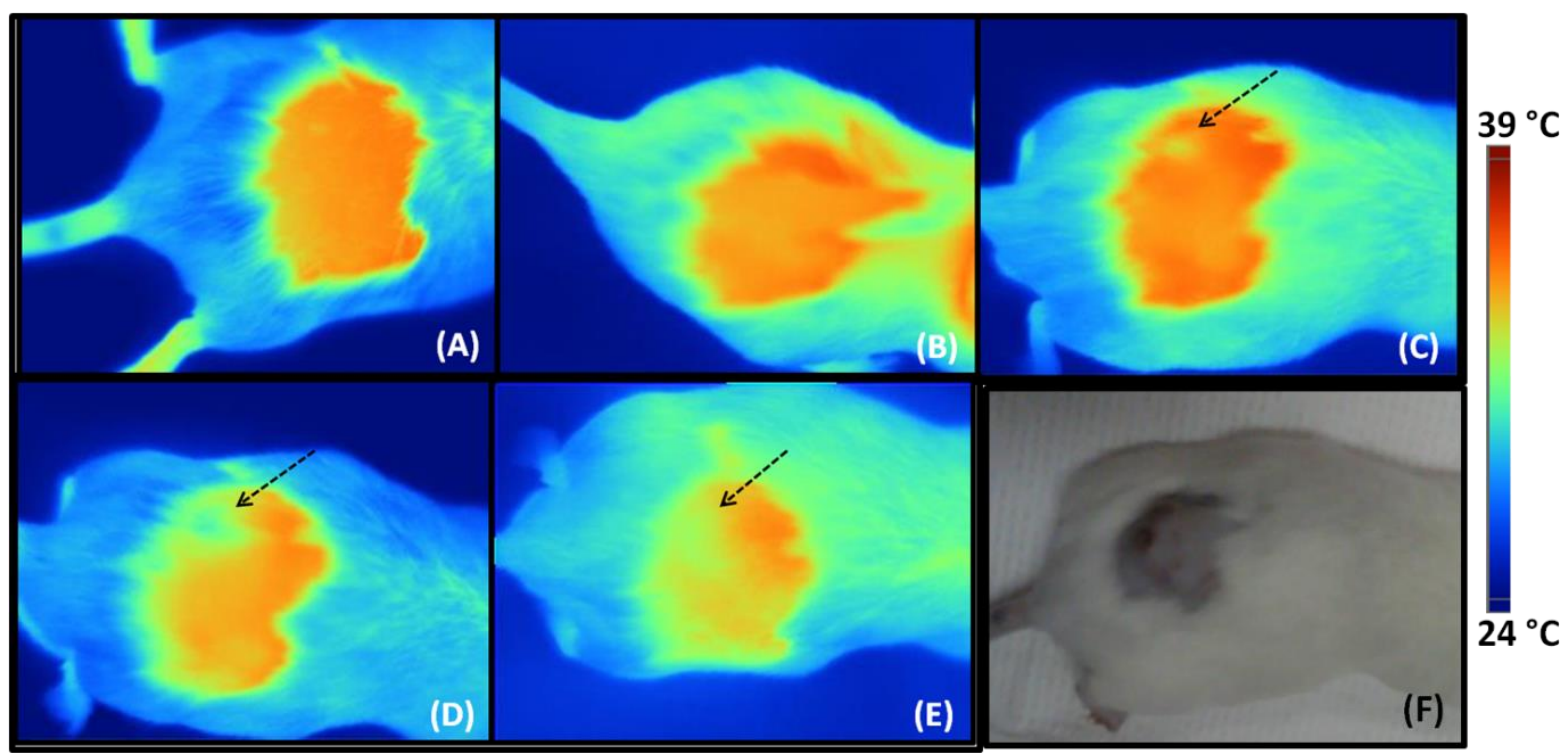

Figura 9 - Imagem de infravermelho do camundongo Swiss (A) logo após tricotomia e em (B), (C), (D) e (E), imagens 2, 4, 7 e 9 dias após a injeção de células de tumor de Ehrlich, (F) imagem de luz branca 9 dias após a injeção.

Fonte: Elaborada pela autora.

Apesar de o tumor já ser palpável 2 dias após a indução, apresentando diâmetro de cerca de $2 \mathrm{~mm}$ (Figura 9), o tumor torna-se evidente na termografia a partir do quarto dia após a indução. O tumor pode ser visto como uma pequena área mais fria dentro da região tricotomizada. $O$ fato de o tumor ser evidenciado como uma 
região de temperatura mais baixa com relação ao tecido ao redor, pode ser explicado pelo fato de o tumor de Ehrlich ser derivado de câncer de mama (53) e os resultados aqui obtidos corroboram os demais estudos da literatura que utilizam outros tipos de tumores de mama (DaRT, MCF-7, MDA-MB-231, Walker 256, 13762 MAT e DA3) em camundongo. Estes estudos verificaram que as baixas temperaturas devem-se ao fato destes tumores serem pouco vascularizados, tornando escasso o fluxo sanguíneo em seu interior. Por isso, uma região de necrose crescente é comumente observada no centro das lesões. A reduzida circulação sanguínea e a presença de região necrótica - e, portanto, de baixa atividade metabólica - contribuem ambas para a detecção de temperaturas inferiores às das médias teciduais locais. $(18,22)$

Além disso, pudemos verificar que nosso equipamento foi sensível para a detecção de tumores de Ehrlich a partir de $4 \mathrm{~mm}$ de diâmetro, o que mostrou uma possibilidade de utilizar o equipamento para analisar pequenas lesões de pele, uma vez que estas, em sua maioria, também apresentam pouca vascularização.

Para a análise destas imagens, foi elaborada uma rotina utilizando o software $M A T L A B \Theta$. A rotina utiliza como dado de entrada a matriz fornecida pelo software da câmera, Fluke SmartView® ${ }^{\circledR}$ 3.5, em formato com extensão ".txt", que apresenta informação de temperatura para cada pixel da imagem. A rotina exibe estas informações em forma de imagem, permitindo delimitação manual da região da lesão. A rotina calcula o valor médio de temperatura com o respectivo desvio padrão na região da lesão investigada.

Nos primeiros dias após a indução tumoral houve dificuldade em localizar e delimitar o tumor via termografia. Assim, em cada animal foi selecionada uma área em torno de onde as células foram injetadas, a qual foi utilizada ao longo de todo o período. Com o valor de temperatura média e seu respectivo desvio na área selecionada, foi possível verificar a variação da temperatura nesta região em relação ao seu valor inicial (Figura $10 \mathrm{~A}$ ). 


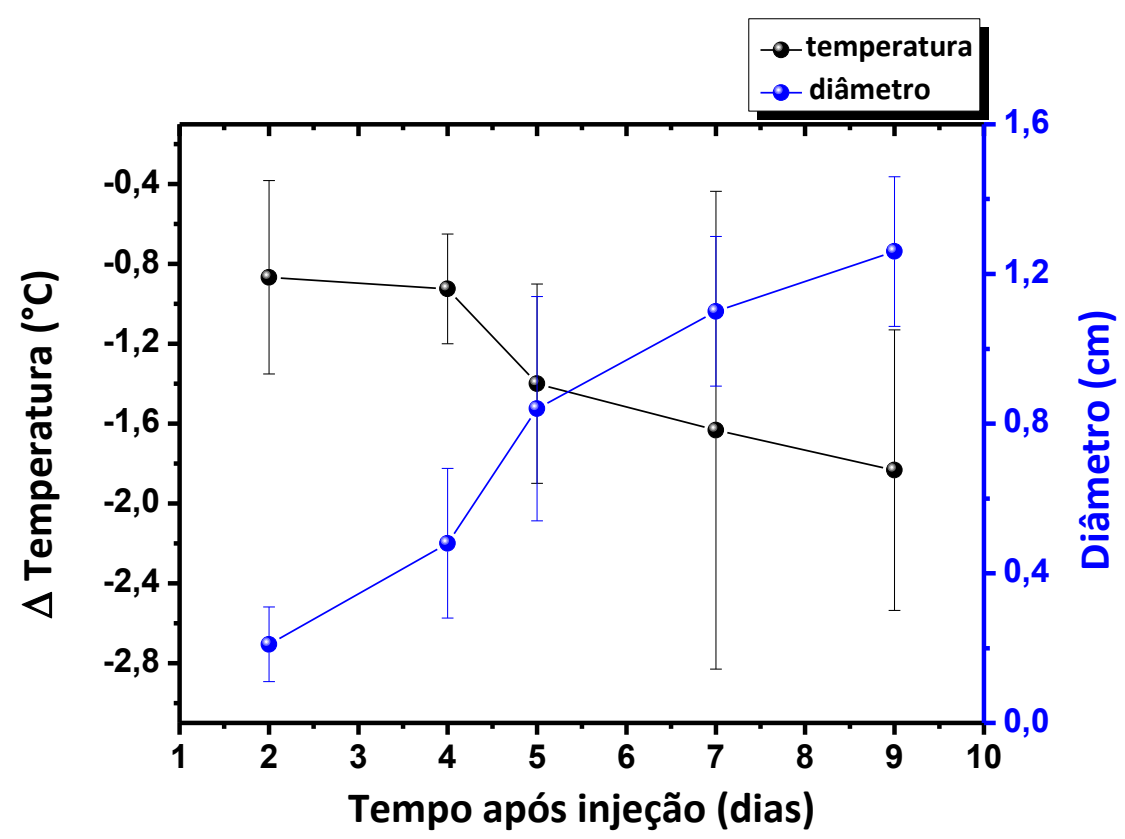

(A)

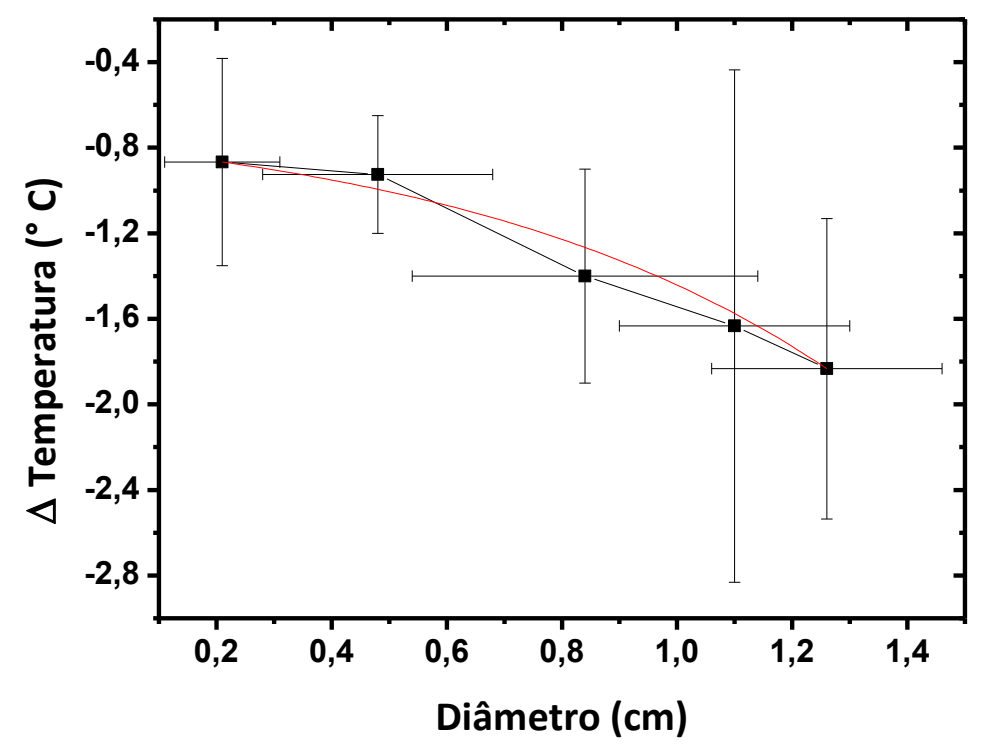

(B)

Figura 10 - (A) Variação da temperatura média na região do crescimento do tumor em relação ao valor inicial e variação do diâmetro médio do tumor, com dados representando média dos nove animais e (B) Ajuste da curva variação da temperatura pela variação do tamanho do tumor em diâmetro.

Fonte: Elaborada pela autora.

A partir do registro do crescimento do tumor destes animais com o uso da termografia, foi possível observar que a temperatura foi decaindo na região do tumor à medida que o volume tumoral foi aumentando como passar dos dias, justificado pelo 
crescimento do tecido de necrose no centro do tumor. Observamos que a variação de temperatura em função do diâmetro do tumor se deu pela expressão: $\Delta T=$ $\frac{1}{(-1,3 \pm 0,1)+(0,6 \pm 0,1) d}$, obtido pelo ajuste da curva da Figura $10 \mathrm{~B}$ (variação da temperatura pela variação do tamanho do tumor em diâmetro). Essa expressão nos mostra que esse comportamento não ocorre de maneira linear e, o aumento do diâmetro da lesão faz com que a temperatura inicial diminua.

No gráfico observamos um desvio padrão bastante significativo, que provavelmente ocorreu devido à grande região que foi demarcada ao redor do tumor. Isto ocorreu devido à dificuldade de delimitar corretamente a área do tumor em seus estágios iniciais, mas foi necessário para garantir que todo o tumor estivesse dentro da área delimitada. Além disso, esta grande variação pode estar relacionada com o desenvolvimento heterogêneo do tumor, pois este tumor tem por característica gande atipia celular, grande quantidade de células anaplásicas e de focos necrópticos. (62)

Os resultados demonstram que a termografia é sensível a alterações térmicas ocasionadas pelo crescimento do tumor sólido. Mesmos nos estágios iniciais do tumor, ou seja, com pequenos diâmetros, a variação térmica já é significativa, provavelmente por ser uma técnica sensível a alterações térmicas relacionadas às alterações metabólicas que ocorrem anteriormente ao desenvolvimento nodular clinicamente perceptível.

Gannot et. al. mostrou que outro tumor derivado de câncer de mama, o modelo MDA-MB-231, ao ser desenvolvido em camundongo também apresenta alteração térmica de $0,5 \mathrm{a} 1^{\circ} \mathrm{C}$ para tumores com apenas $2 \mathrm{~mm}$ de raio. $\mathrm{E}$ esta diferença é de $1,2 \mathrm{a} 2,3^{\circ} \mathrm{C}$ para tumores com raio de $4 \mathrm{~mm}$. (18) Estes valores corroboram com os valores encontrados neste estudo utilizando modelo de Ehrlich, provavelmente pelas semelhanças de estruturas, metabolismo, taxa de crescimento e distribuição de vasos no tecido.

Esses resultados também demonstram que a termografia pode ser empregada para monitorar o crescimento de um tumor sólido subcutâneo com grande capacidade de detecção mesmo nos estágios iniciais do desenvolvimento. 
5.1.2. Variação de temperatura durante a TFD em pele sadia de animal

A fim de verificar a alteração térmica causada no tecido por efeito apenas da iluminação, foram registradas imagens de termografia a cada 2 minutos durante os 20 minutos de iluminação, e a cada 1 minuto após a iluminação para acompanhar o resfriamento do tecido. Este procedimento foi realizado no dorso de 3 animais, porém a Figura 10 mostra o resultado da termografia em apenas um animal, a título de exemplo, visto que o comportamento foi semelhante nos três animais. Na Figura 11, podemos observar a região do dorso do animal ao longo do procedimento de TFD e após o término da iluminação. É possível observar que a iluminação da pele com luz vermelha em $630 \mathrm{~nm}$, entregando $125 \mathrm{~mW} / \mathrm{cm}^{2}$ de intensidade, por si só promove um aquecimento de cerca de $4^{\circ} \mathrm{C}$.

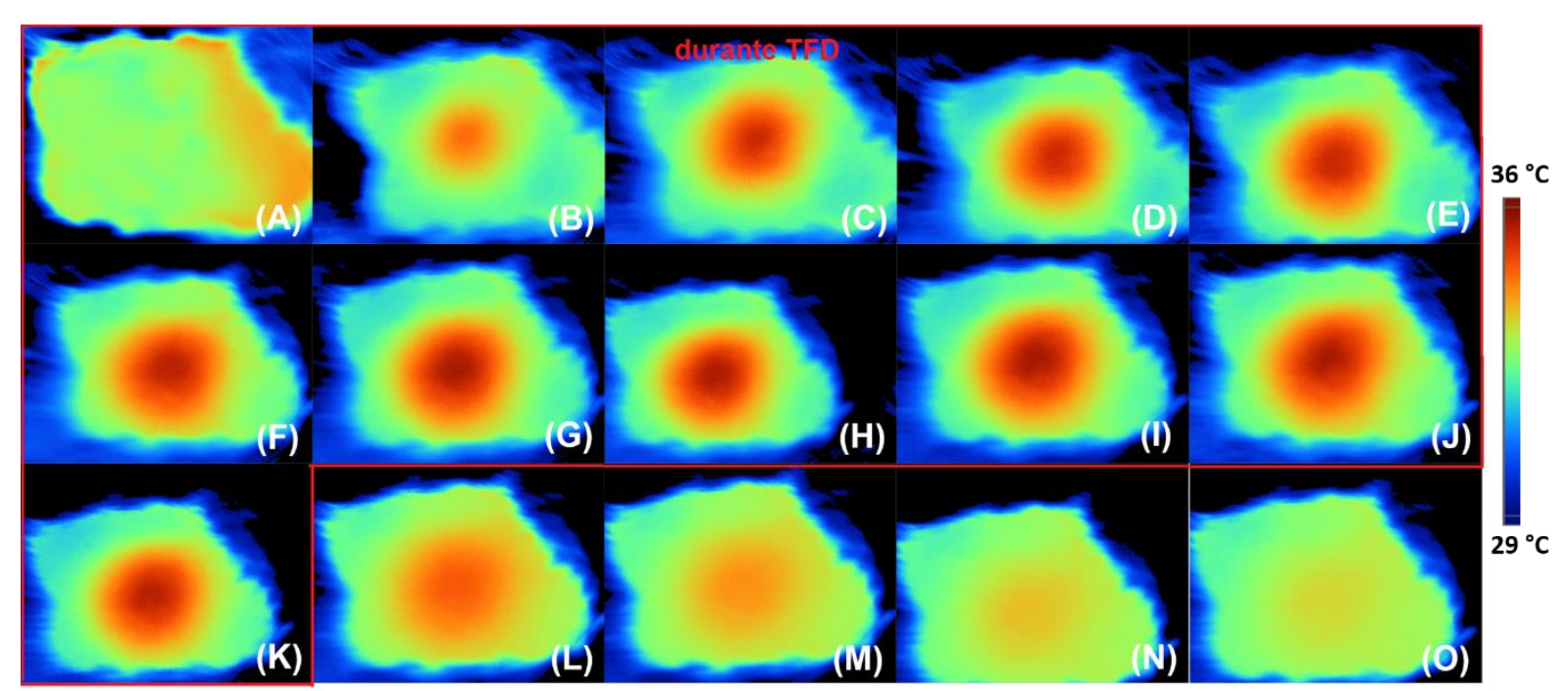

Figura 11 - Dorso do camundongo durante iluminação (A) 0, (B) 2, (C) 4, (D) 6, (E) 8, (F) 10, (G) 12, (H) 14, (I) 16, (J) 18 e (K) 20 minutos; e após iluminação (L) 1, (M) 2, (N) 3 e (O) 4 minutos.

Fonte: Elaborada pela autora

Os gráficos da Figura 12 mostram a variação da temperatura em função do tempo de iluminação comparando as situações em que não houve fotossensibilização ( $A$ e B) com a fotossensibilização seguida de iluminação para a pele íntegra (C e D) e pele curetada (E e F). 


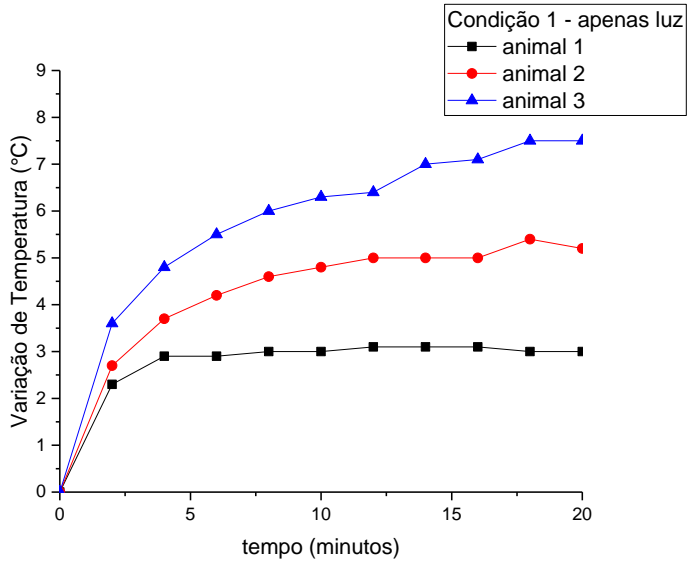

(A)

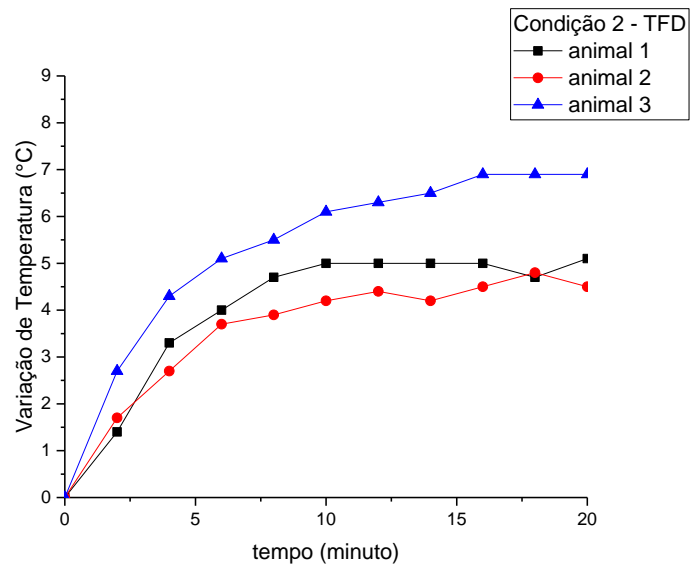

(C)

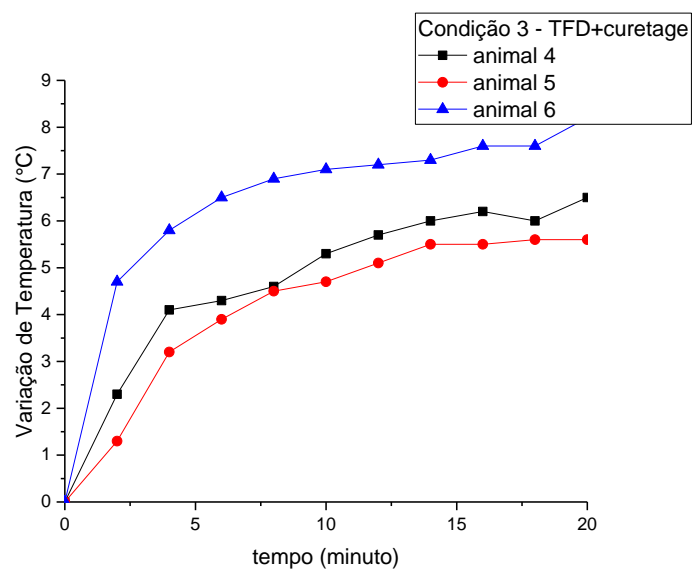

(E)

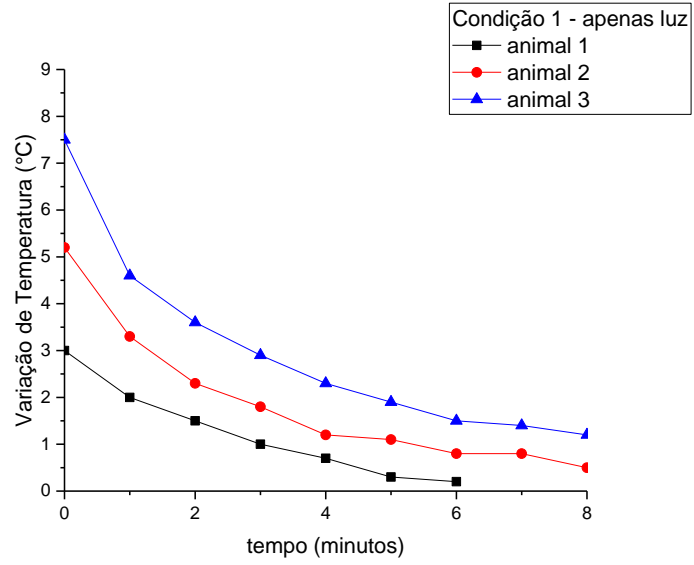

(B)

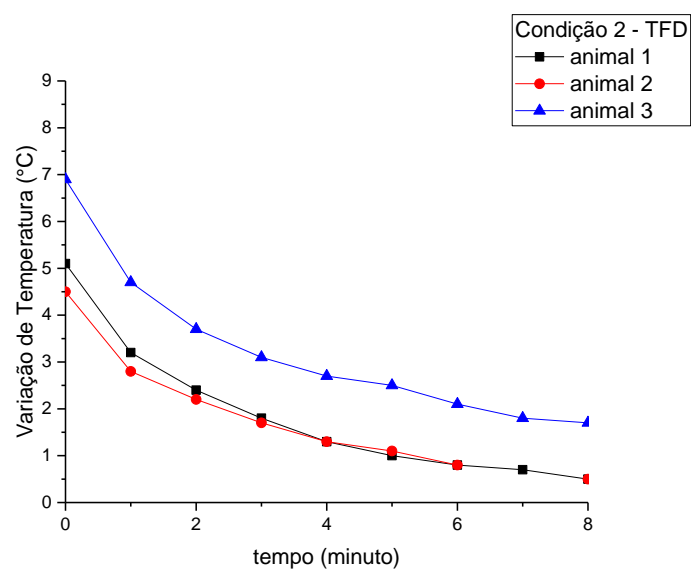

(D)

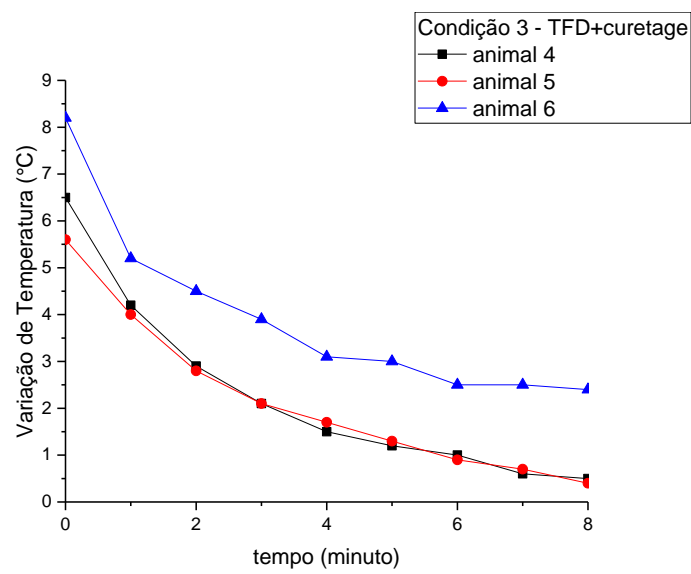

(F)

Figura 12 - (A) e (B) Curvas de aquecimento durante iluminação e resfriamento após o término da iluminação dos animais sem administração prévia do Metil-ALA, respectivamente; (C) e (D) curvas de aquecimento durante iluminação e resfriamento após o término da iluminação dos animais durante o procedimento de TFD em tecido normal; (E) e (F) curvas de aquecimento durante iluminação e resfriamento após o término da iluminação dos animais durante o procedimento de TFD em que foi realizada curetagem de $1 \mathrm{~cm}$ de diâmetro para simular uma lesão.

Fonte: Elaborada pela autora 
Em geral, podemos observar que a TFD não alterou os comportamentos de temperatura, tanto seu crescimento durante iluminação quanto o resfriamento subsequente. Além disso, o aumento de temperatura foi levemente maior no grupo com curetagem. Esse comportamento está possivelmente correlacionado ao dano mecânico realizado pela curetagem, que já induz a liberação de citocinas inflamatórias e conseqüente hipertermia.

Outro fato que se pode notar é que a temperatura tem maior crescimento nos cinco minutos iniciais de iluminação; depois deste período, ela tende a se estabilizar, com pouca alteração. Esta observação corrobora com o observado por Orenstein et al., eles visualizaram este mesmo comportamento em lesões de CBC e QA durante o procedimento de TFD utilizando ácido aminulevulinico topicamente e ilmuminando com $100 \mathrm{~mW} / \mathrm{cm}^{2}$ durante 20 minutos. Eles monitoraram lesões situadas na face de 22 pacientes e constataram que o aumento de temperatura na região circundante à lesão foi de $3,9 \pm 0,5{ }^{\circ} \mathrm{C}$ nos primeiros 5 minutos e de $2,0 \pm 0,4{ }^{\circ} \mathrm{C}$ ao final de 20 minutos de iluminação. (63) Esta variação foi semelhante ao que observamos durante os primeiros 5 minutos de iluminação dos animais, porém este valor se manteve ao longo da iluminação e não sofreu diminuição como observado por Orenstein, provavelmente por conta da vascularização diferenciada em um tecido com presença de tumor. É importante notar que o aumento de temperatura induzido pela iluminação ou pela TFD não é suficientemente grande a ponto de induzir dano térmico.

\subsection{Estudo Clínico}

\subsubsection{Discriminação de lesões clinicamente semelhantes}

\subsubsection{Carcinoma basocelular $\mathrm{x}$ nevo intradérmico}

Imagens termográficas de lesões da pele foram registradas e através destas buscamos encontrar um padrão de temperatura que possa ser utilizado para a discriminação das mesmas. Destas imagens, um dos pares de lesão clinicamente semelhante investigado nesse estudo foi o $\mathrm{CBC}$ x nevo intradérmico. Foram coletadas 
imagens térmicas de 100 pacientes com lesão do tipo CBC e 100 com lesão do tipo nevo intradérmico.

Na Figura 13 podemos observar exemplos de imagens termográficas de quatro lesões do tipo CBC nodular. Nestas imagens observamos que este tipo de lesão apresenta temperatura menor do que o tecido saudável ao redor e, no geral, suas bordas não são bem delimitadas. $O$ fato das bordas não serem bem delimitadas termicamente, significam que a temperatura da lesão não muda abruptamente na transição das brodas para a região sadia, ou seja, a variação de temperatura é bastante gradual, o que impede a delimitação das bordas através da termografia.

Esse comportamento de menor temperatura na lesão e bordas não bem delimitadas foi verificado em $84 \%$ das lesões de CBC registradas, nas demais lesões haviam presença de crosta (que apresenta baixa temperatura) e fez com que as bordas dessas lesões fossem realçadas, além de que esta ulceração muitas vezes causa inflamação ao redor da lesão realçando ainda mais o seu contorno ao contrastar com a crosta.

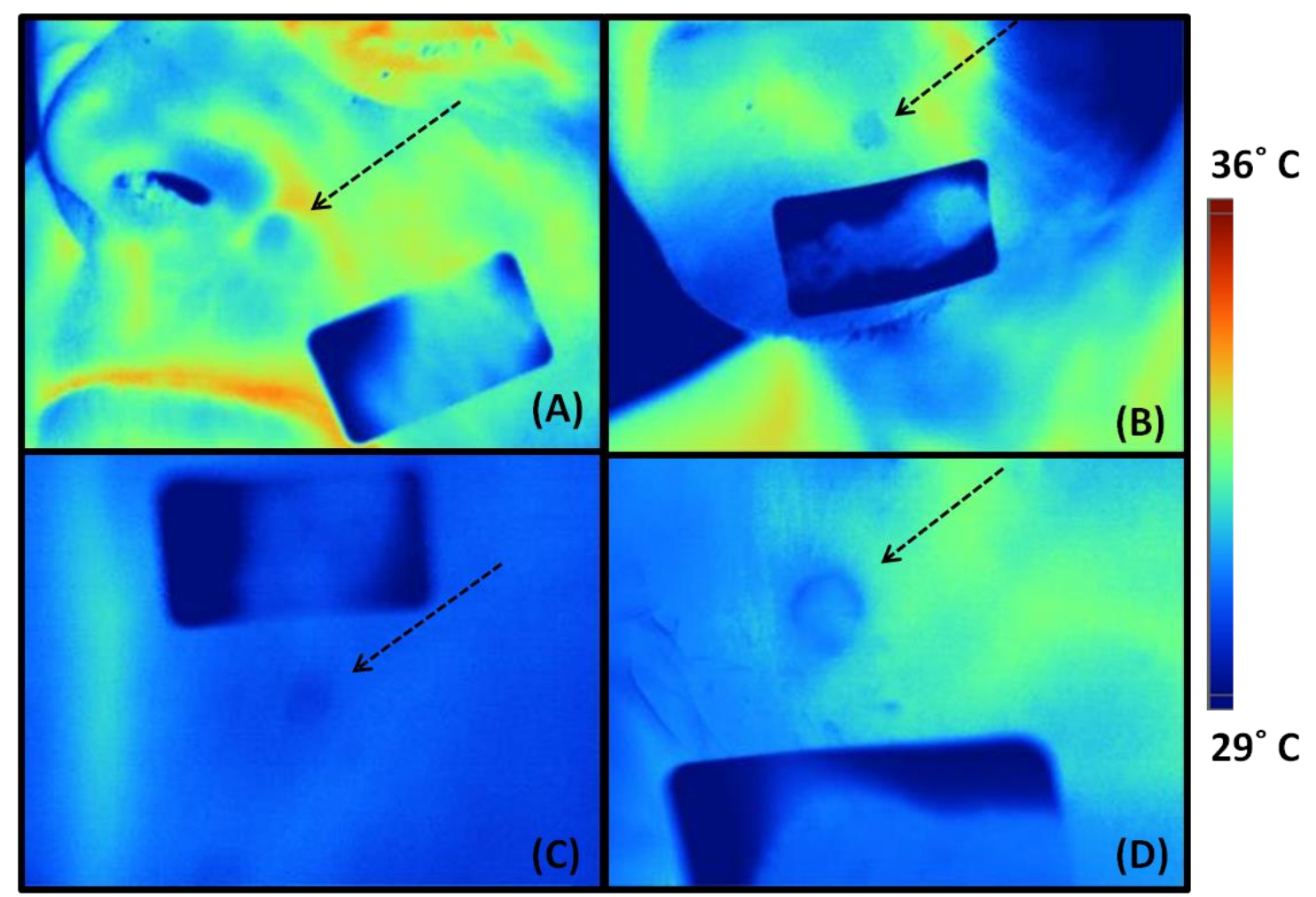

Figura 13 - Imagens termográficas de lesões do tipo CBC nodular. Fonte: Elaborada pela autora. 
Selecionando uma lesão de CBC nodular, podemos analisar outros aspectos. Como podemos observar na imagem de luz branca (Figura $14 \mathrm{~A}$ ), as lesões deste tipo são nodulares e não pigmentadas. A lesão encontra-se em uma região com distribuição de temperatura bastante heterogênea (Figura 14 B), na qual os pontos da lesão apresentam valores de temperatura menor $\left(32,7^{\circ} \mathrm{C}\right)$ se comparada ao tecido ao redor $\left(33,0\right.$ e $\left.33,4^{\circ} \mathrm{C}\right)$.

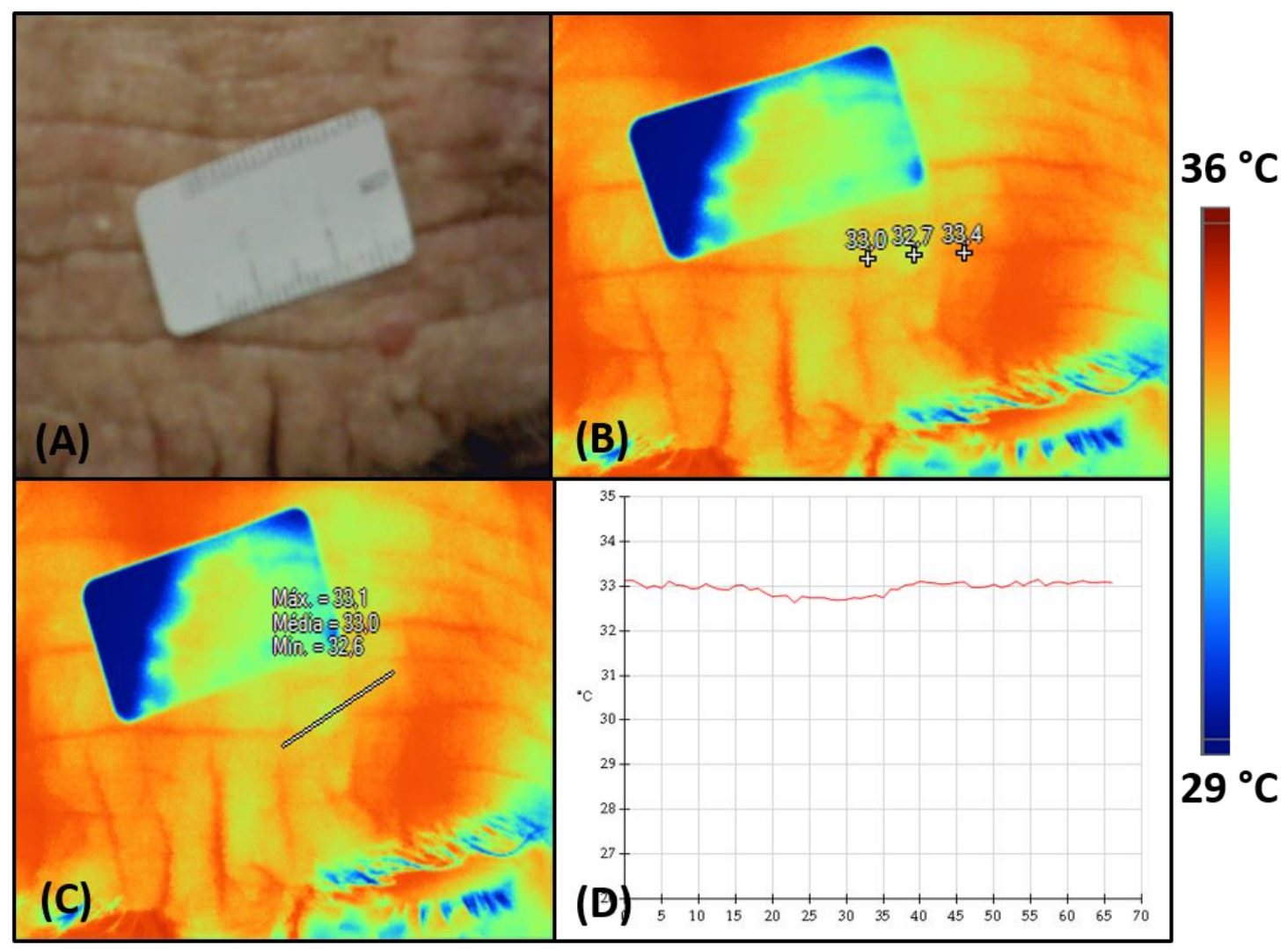

Figura 14 - (A) Imagem de luz branca de uma lesão do tipo CBC nodular, (B) imagem de infravermelho da lesão com valores de temperatura em alguns pontos da imagem, $(C)$ reta traçada cortando o centro da lesão, e (D) seu respectivo gráfico de temperatura em função dos pixels da imagem, em uma linha que atravessa o centro da lesão. A barra lateral à direita indica a escala de temperatura compreendida nas imagens $(B)$ e $(C)$.

Fonte: Elaborada pela autora

O fato do $\mathrm{CBC}$ apresentar temperatura menor que o tecido saudável adjacente está em concordância com o trabalho publicado por Buzug et al., que inclusive demonstrou que quando um $\mathrm{CBC}$ é resfriado (por transferência de calor através da pele) a uma temperatura de $27^{\circ} \mathrm{C}$, a sua regularização térmica também é mais lenta que a do tecido sadio circundante, por conta de ser uma lesão pouco vascularizada. (33) Utilizando o software comercial do equipamento, também foi possível traçar um 
segmento de reta que atravessa o centro da lesão, compreendendo a lesão entre duas regiões de tecidos normais (Figura $14 \mathrm{C}$ ). O gráfico da variação de temperatura da reta em função dos pixels da imagem (Figura $14 \mathrm{D}$ ) foi obtido com a informação dos pixels demarcados pela linha traçada. Pelo gráfico podemos observar que, nas regiões de normalidade, o tecido possui uma temperatura praticamente constante, em torno de $33,0^{\circ} \mathrm{C}$, que então decai ao se aproximar da borda da lesão (a partir do $20^{\circ}$ pixel), até que a temperatura chega ao valor mínimo de aproximadamente $32,7 \stackrel{\circ}{\circ} \mathrm{C}$. Ao atravessar a lesão, a temperatura volta a aumentar na fronteira do tecido normal (próximo do $35^{\circ}$ pixel) retornando a uma temperatura média de $33,0^{\circ} \mathrm{C}$. Por conta das diferenças na curvatura do tecido ao se afastar da região de foco para coleta da imagem, parte da informação térmica pode ser perdida no registro devido à menor detecção de radiação infravermelha. Este registro de menor temperatura também pode ser resultado de temperatura mais baixa na porção mais à direita na imagem.

$\mathrm{Na}$ Figura 15 podemos observar exemplos de imagens termográficas de quatro lesões do tipo nevo intradérmico. Nestas imagens podemos observar que este tipo de lesão apresenta temperatura menor do que o tecido saudável ao redor e, no geral, suas bordas são mais bem delimitadas que as lesões do tipo CBC nodular. Esse comportamento foi verificado em $76 \%$ das lesões registradas, as demais lesões ou estavam em regiões com presença de pelos ou possuíam tamanho muito pequeno, tais fatos fizeram com que estas lesões tivessem suas bordas pouco evidenciadas nas imagens. 


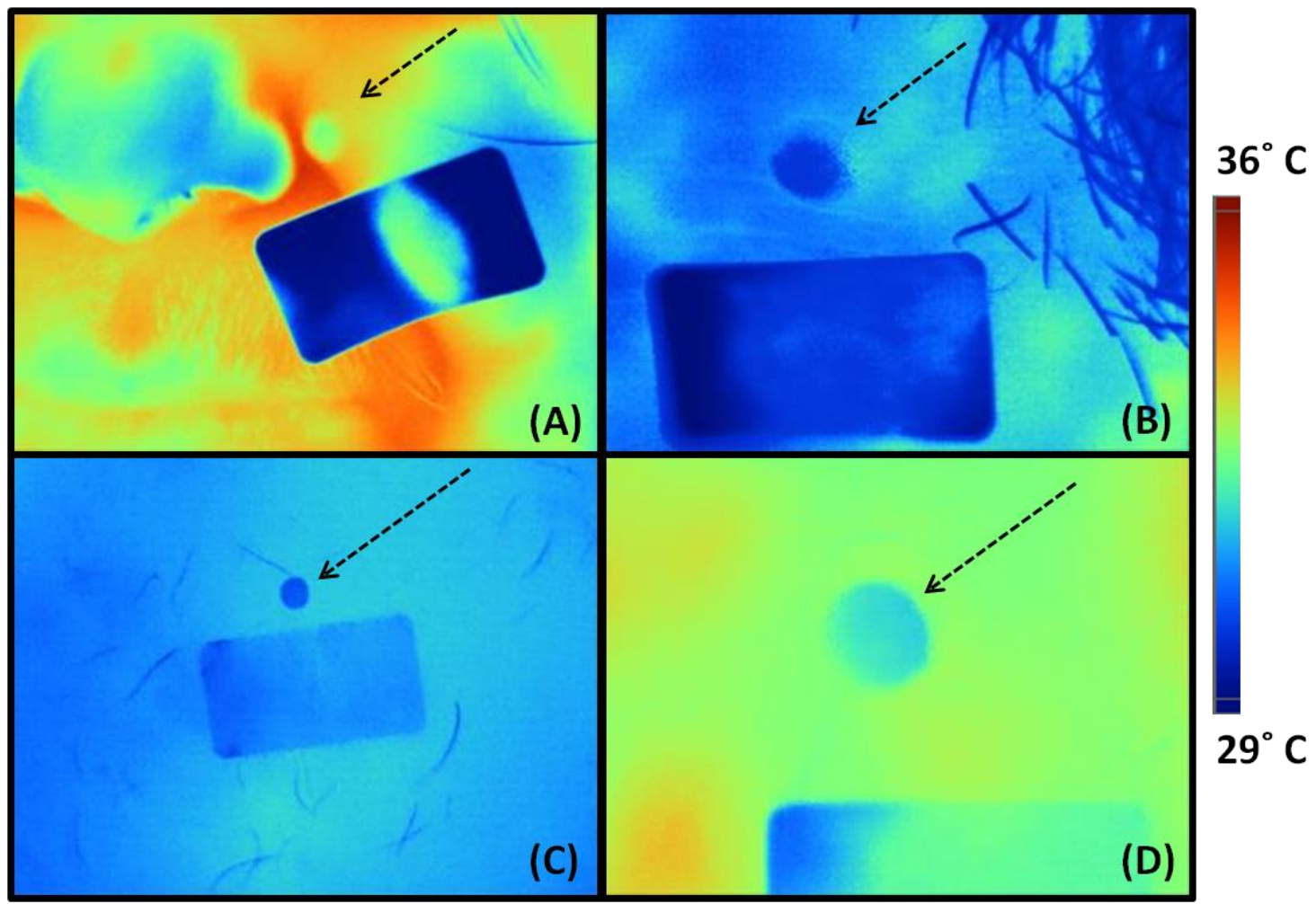

Figura 15 - Imagens termográficas de lesões do tipo nevo intradérmico. Fonte: Elaborada pela autora.

Analisando uma lesão desse tipo com mais detalhes, podemos observar as características da lesão numa imagem de luz branca (Figura 16 A). Observamos que esta lesão também é nodular e não pigmentada, e em geral não apresenta ulceração por ser tratar de uma lesão benigna. 


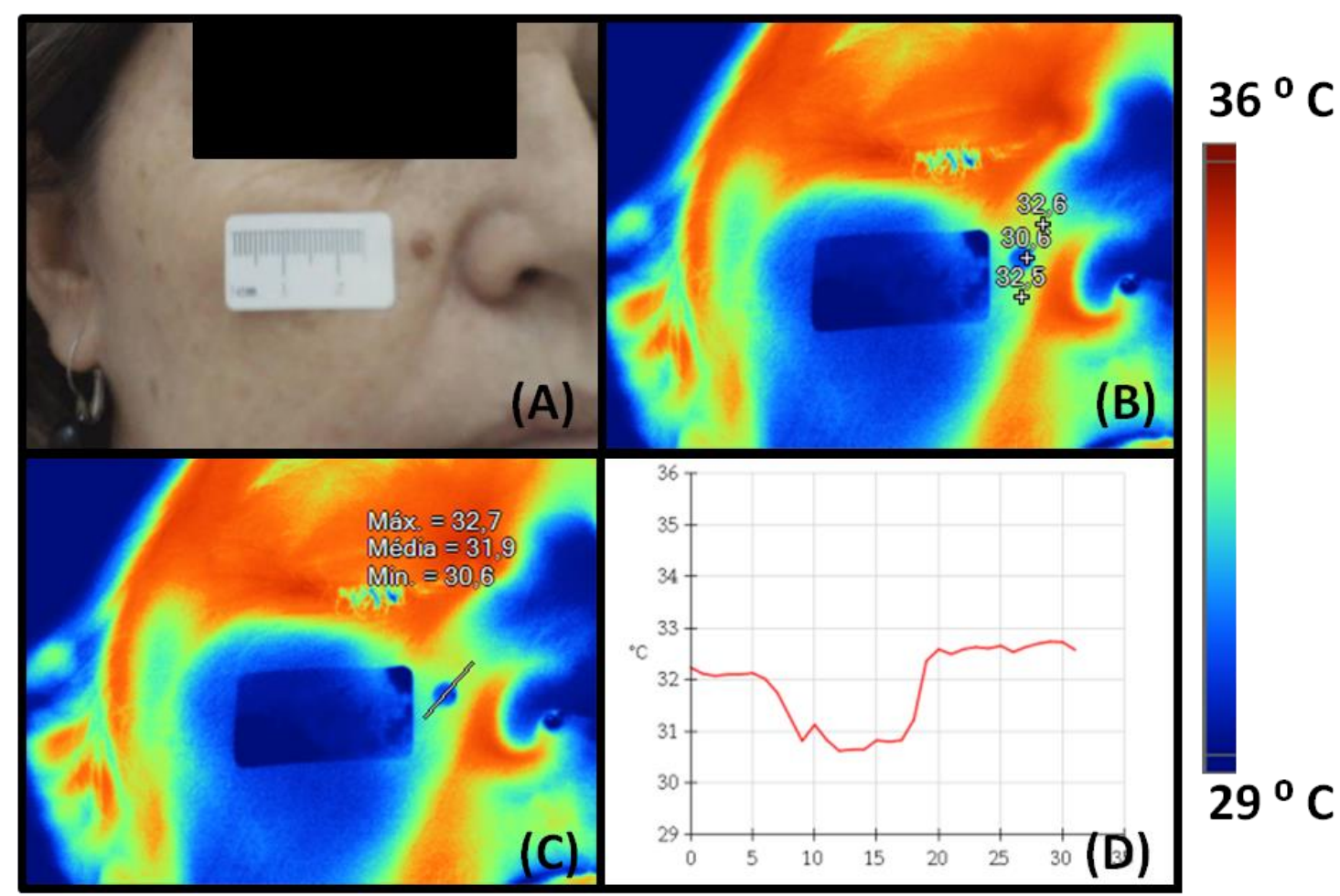

Figura 16 - (A) Imagem de luz branca de uma lesão do tipo nevo intradérmico, (B) imagem de infravermelho da lesão com valores de temperatura em alguns pontos da imagem, (C) reta traçada cortando o centro da lesão, e (D) seu respectivo gráfico de temperatura em função dos pixels da imagem. A barra lateral à direita indica a escala de temperatura compreendida nas imagens (B) e (C).

Fonte: Elaborada pela autora

Assim como o CBC, os nevos intradérmicos apresentam temperatura menor que a do tecido ao redor; porém possuem bordas termicamente mais bem definidas, e nestas lesões é menos evidente a presença de gradientes de temperatura ao redor da lesão. As lesões de nevo (Figura 16) comparadas às de CBC (Figura 14) apresentaram menor diferença de temperatura na lesão em relação à temperatura de fora (nas lesões exploradas nas Figuras 16 e 14 o nevo variou de $32,6^{\circ} \mathrm{C}$ na parte externa para $30,6^{\circ} \mathrm{C}$ dentro da lesão, enquanto que no CBC essa diferença foi de 33,0 para $32,7^{\circ} \mathrm{C}$ na parte interna da lesão, em média).

Utilizando o mesmo software, novamente traçamos um segmento de reta que compreende o centro da lesão, passando por duas regiões de tecidos normais (Figura 16 C), e construímos um gráfico da variação de temperatura da reta em função do pixel da imagem (Figura $16 \mathrm{D}$ ). Nas imagens de termografia, os nevos intradérmicos mostraram maior diferença de temperatura com relação ao tecido normal, visto que o contorno delas é mais bem definido e aparentam exibir maior contraste na imagem. Além disso, pela curva traçada, também verificamos a maior diferença de temperatura 
na região da lesão neste caso (em torno de $1,5^{\circ} \mathrm{C}$, enquanto a do $\mathrm{CBC}$ é de aproximadamente $0,3^{\circ} \mathrm{C}$ ). Este decaimento também é mais acentuado, justificando a melhor definição das bordas.

\subsubsection{Carcinoma espinocelular $x$ queratoses actínicas}

Exemplos de imagens de lesões do tipo CEC registradas pela termografia estão apresentadas na Figura 17. Foram coletadas imagens térmicas de 35 pacientes com lesão do tipo CEC e 35 com lesão do tipo QA.

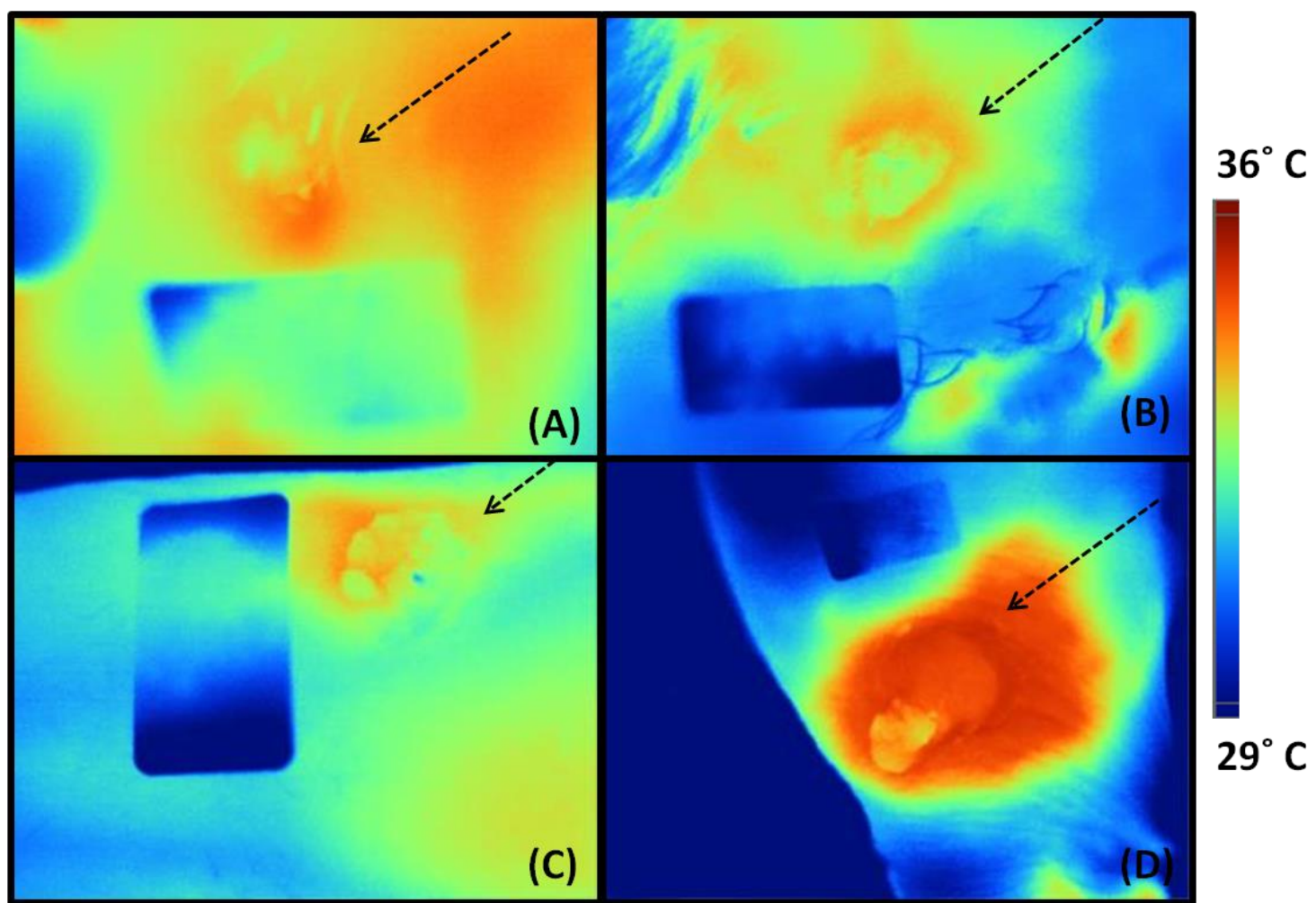

Figura 17 - Imagens termográficas de lesões do tipo CEC.

Fonte: Elabora pela autora.

Nestas lesões, podemos observar que geralmente (em 74\% das lesões registradas) a temperatura é mais elevada na região da lesão e em uma área circundante. Isto provavelmente deve-se às características da lesão, como crescimento rápido e alta agressividade, o que também aumenta fatores angiogênicos. (28) Os demais $26 \%$ das lesões tratavam-se de lesões pequenas e em 
regiões com presença de pelos, geralmente membros superiores que são mais expostos ao sol. A baixa alteração térmica (devido ao tamanho da lesão) somada a presença dos pelos fizeram com que o sistema fosse pouco sensível na detecção da alteção térmica.

Selecionando uma lesão de CEC, podemos explorar outras características na Figura 18.

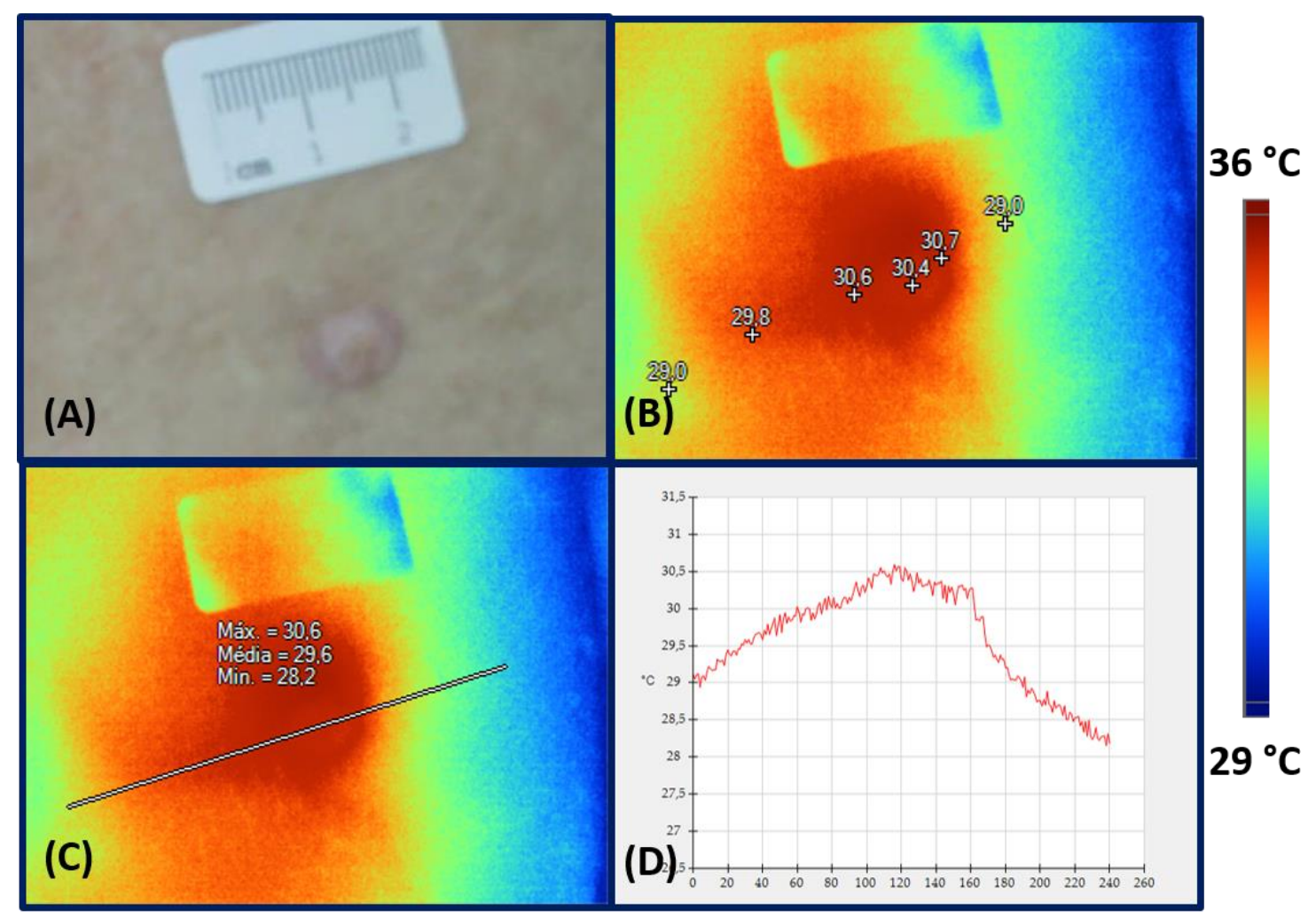

Figura 18 - (A) Imagem de luz branca de uma lesão do tipo CEC, (B) imagem de infravermelho da lesão com valores de temperatura em alguns pontos da imagem, (C) reta traçada cortando o centro da lesão, e (D) seu respectivo gráfico de temperatura em função dos pixels da imagem. A barra lateral à direita indica a escala de temperatura compreendida nas imagens $(B)$ e $(C)$.

Fonte: Elaborada pela autora.

O CEC apresentou temperatura maior na região da lesão se comparado com o tecido sadio. Também é possível observar que existe um aumento de temperatura numa região logo ao redor da lesão. Na Figura $18 \mathrm{~B}$, verifica-se que enquanto a temperatura na região interna da lesão é de $30,4{ }^{\circ} \mathrm{C}$, logo ao redor observa-se valores de 30,6 e $30,7^{\circ} \mathrm{C}$. Em uma região mais afastada, onde a vascularização normal é 
semelhante à observada em tecido normal, é possível observar que a temperatura do tecido é menor.

Traçando um segmento de reta que passa pelo centro da lesão, compreendendo a lesão entre duas regiões de tecidos normais (Figura $18 \mathrm{C}$ ), obtevese o gráfico da variação de temperatura da reta (Figura $18 \mathrm{D}$ ). Pelo gráfico, é possível observar que a temperatura vai aumentando até chegar, na região da lesão, a aproximadamente $30,4^{\circ} \mathrm{C}$ (a partir do $100^{\circ}$ pixel), e volta a decair após atravessar a lesão (perto do $160^{\circ}$ pixel).

Exemplos de imagens termográficas coletadas de lesões do tipo QA estão apresentadas na Figura 19. Pelas imagens, pode-se notar que quase não existe diferença de temperatura da região da lesão em comparação à região circundante (padrão verificado em $88 \%$ das lesões registradas), com exceção da observação de menores temperaturas em locais onde são verificadas a presença de crostas, provocadas por pequenas ulcerações. Os demais $12 \%$ das lesões mostraram aumento de temperatura na região da lesão, este comportamento sugere que tais lesões tenham elevado grau de infiltração, ou até mesmo, esteja em transformação para uma lesão maligna do tipo CEC. 


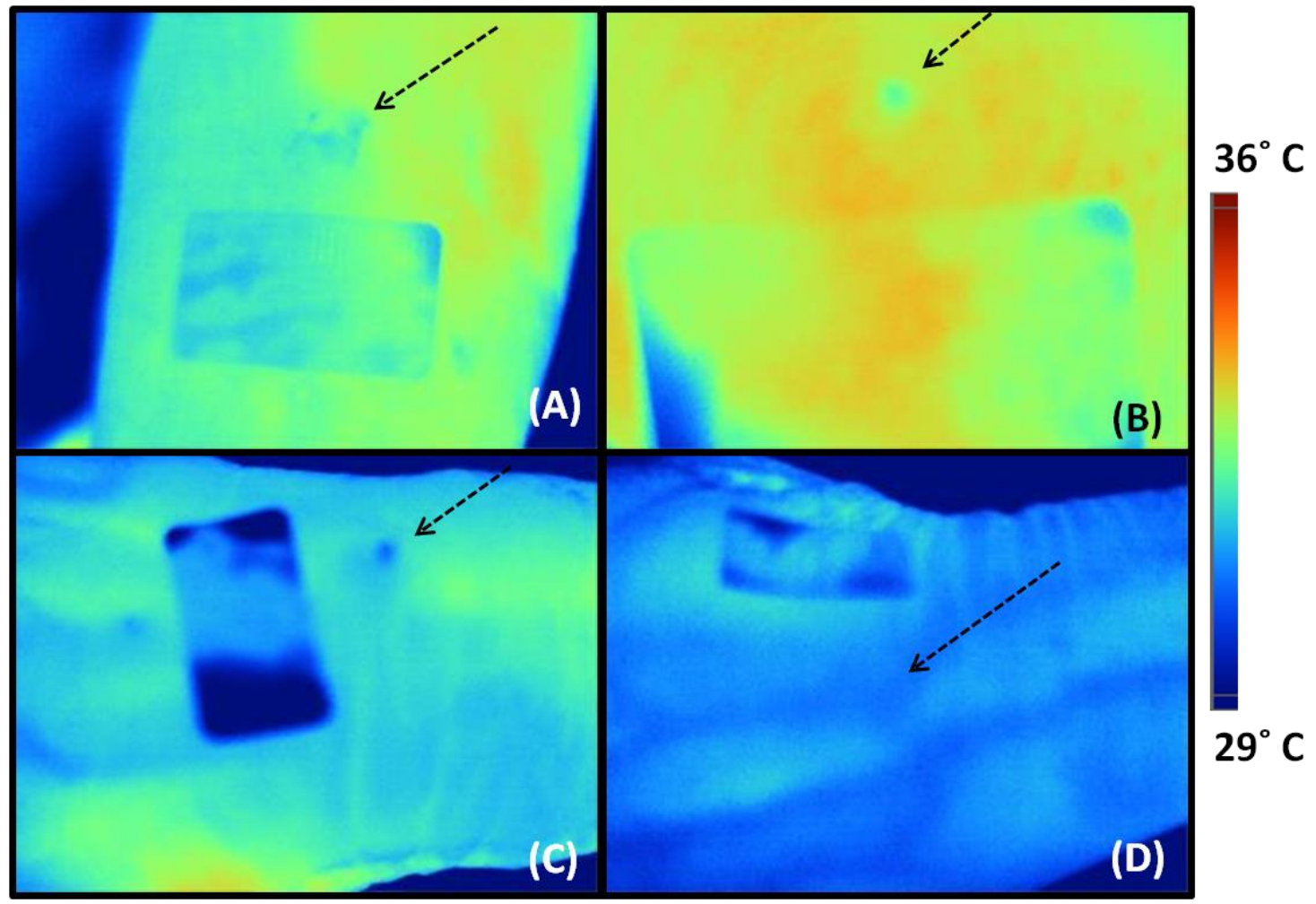

Figura 19 - Imagens termográficas de lesões do tipo QA. As lesões exibidas em (B) e (C) apresentam regiões com menores temperatura devido à presença de crostas, enquanto as lesões exibidas em (A) e (D) apresentam pouca diferença de temperatura em relação ao tecido ao redor.

Fonte: Elaborada pela autora.

Selecionando uma imagem de lesão de $Q A$, pode-se analisá-la mais detalhadamente na Figura 20. 


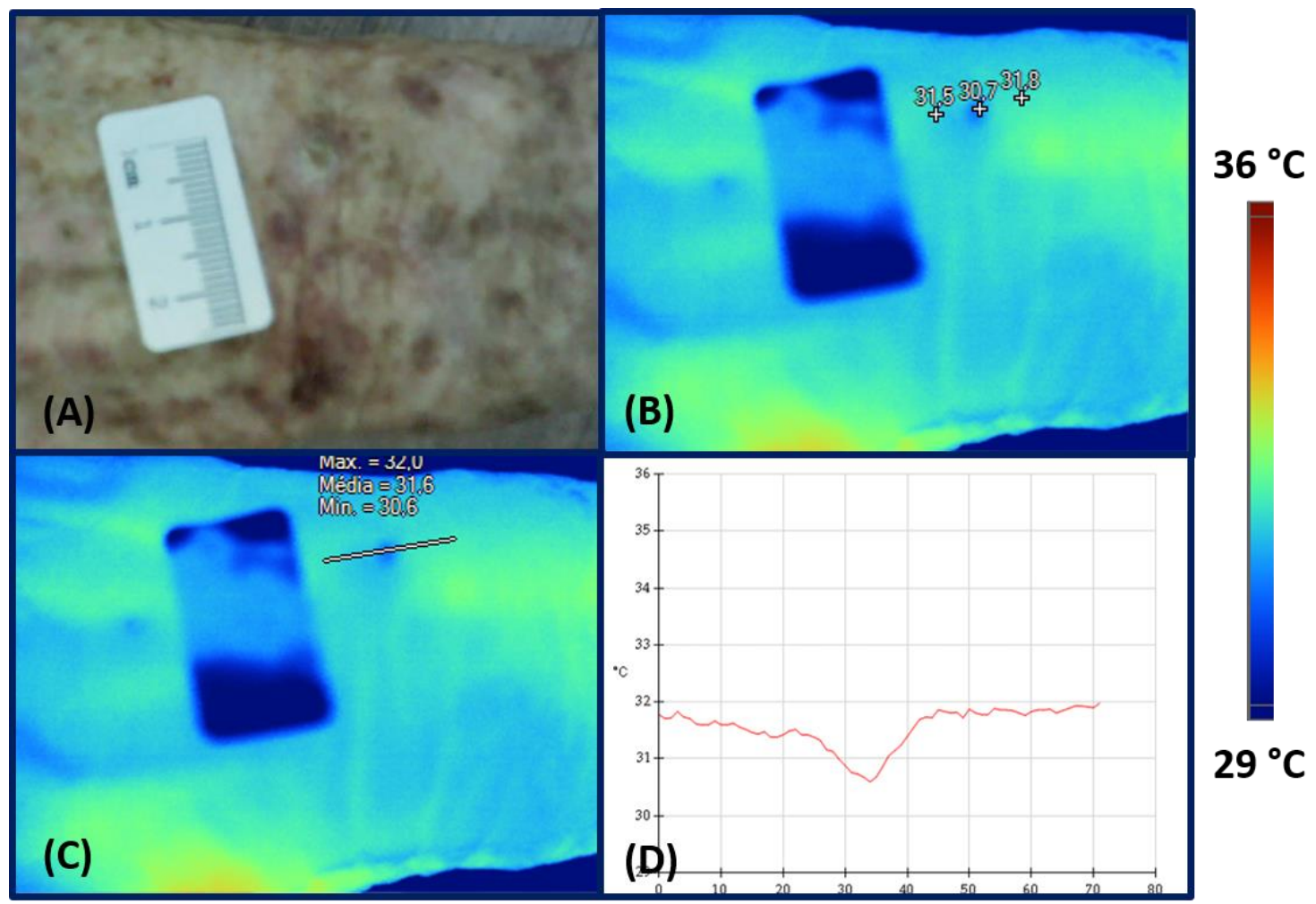

Figura 20 - (A) Imagem de luz branca de uma lesão do tipo QA, (B) imagem de infravermelho da lesão com valores de temperatura em alguns pontos da imagem, $(C)$ reta traçada cortando o centro da lesão, e (D) seu respectivo gráfico de temperatura em função dos pixels da imagem. A barra lateral à direita indica a escala de temperatura compreendida nas imagens $(B)$ e $(C)$.

Fonte: Elaborada pela autora.

A QA exemplificada na Figura 20 B apresentou menor temperatura em relação à temperatura adjacente: nela, encontra-se um valor de $30,7^{\circ} \mathrm{C}$ na parte interna da lesão, enquanto ao redor apresentou valores de 31,5 e $31,8^{\circ} \mathrm{C}$. Este comportamento hipotérmico provavelmente pode ser associado à crosta presente na lesão, mostrada na Figura $20 \mathrm{~A}$.

O segmento de reta atravessando a lesão (Figura 20 C) e o consequente gráfico da variação de temperatura (Figura 20 D) mostram o decaimento de temperatura na região da lesão. A temperatura se manteve praticamente constante, em $31,7{ }^{\circ} \mathrm{C}$, até chegar em uma das extremidades da lesão (em torno do 25ำ pixel), a partir de onde sua temperatura decai até cerca de $30,7^{\circ} \mathrm{C}$, e volta a subir e ficar constante, em cerca de $31,8^{\circ} \mathrm{C}$, ao passar pela outra extremidade da lesão (em torno do $42^{\circ}$ pixel).

A QA pode evoluir e se transformar num CEC. A dificuldade em distinguir tais lesões está no fato que esta evolução ocorre de maneira gradual, de modo que as duas variedades de lesão podem estar simultaneamente presentes na mesma região, aumentando a dificuldade de diagnóstico de CEC por dermatoscopia. (64) Entretanto, 
entre os pares de lesões analisados neste estudo, o par CEC versus QA foi o que mostrou maior diferença através da termografia, pois a região do CEC apresentou maior temperatura média em relação ao tecido saudável, provavelmente devido à sua característica de rápido crescimento e maior agressividade (28), enquanto as imagens de QA quase não apresentaram diferença de temperatura em comparação com a região circundante.

\subsubsection{Melanoma x queratose seborreica pigmentada}

Exemplos das imagens termográficas das lesões dos tipos melanoma nodular estão apresentados na Figura 21. Foram coletadas imagens térmicas de 20 pacientes com lesão do tipo melanoma e 20 com lesão do QSP.

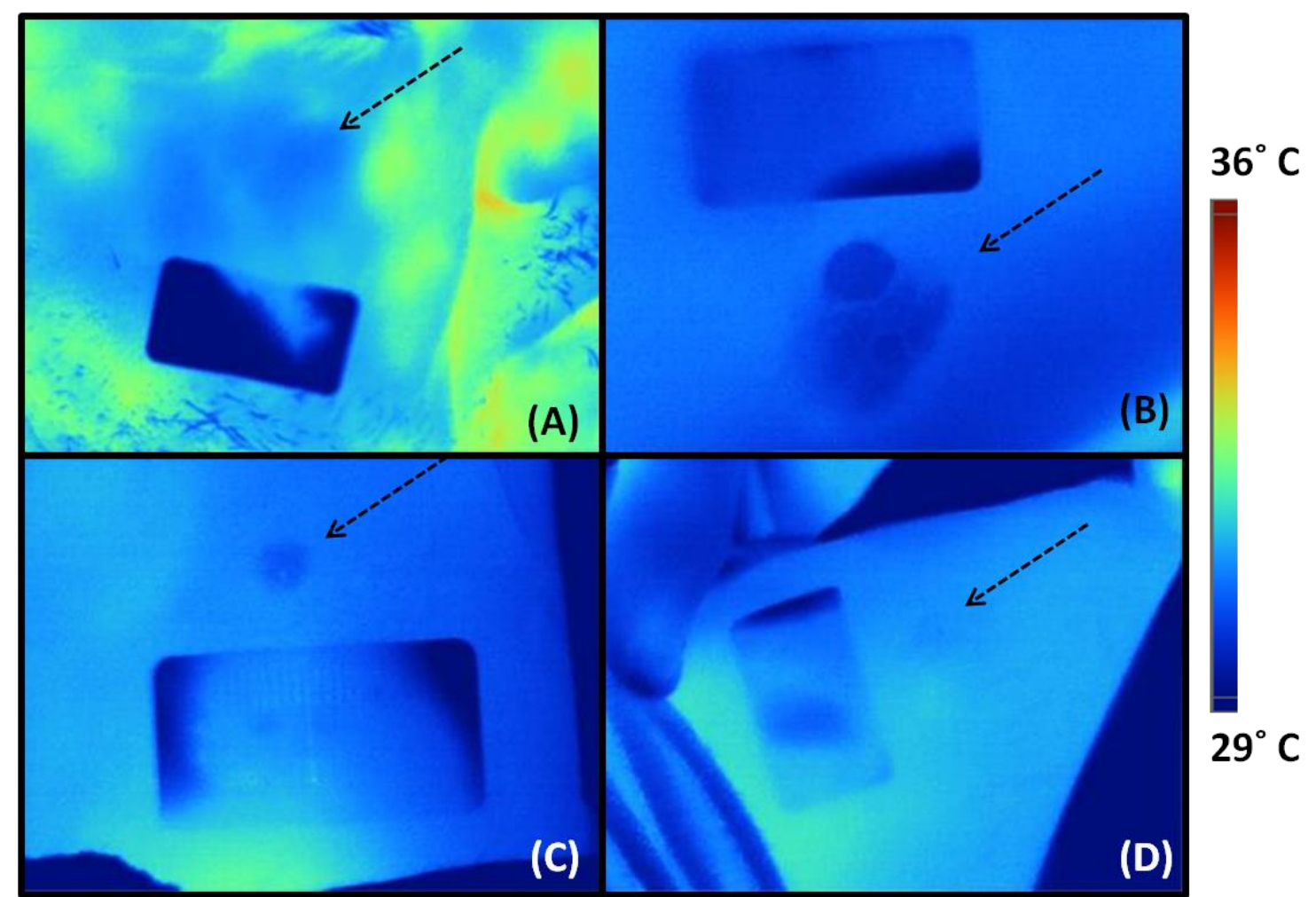

Figura 21 - Imagens termográficas de lesões do tipo melanoma.

Fonte: Elaborada pela autora.

Nas lesões do tipo melanoma, observamos pela termografia, em $86 \%$ das lesões registradas, menor temperatura no local da lesão, com pouca definição de 
bordas. Os demais $14 \%$ das lesões eram ulceradas com presença de crosta e inflamação ao redor ou eram mais nodulares fazendo com que suas bordas fossem realçadas.

O melanoma tem como característica alta agressividade e potencial de metastatização. As condições que levam a essas características poderiam causar aumento da temperatura; porém, observa-se que a temperatura da lesão é menor que a da região ao redor, e que as bordas são bastante difusas. Esta observação está de acordo com o estudo de Shada et al. que sugere que lesões de melanoma pequenas e primárias têm neovascularização limitada e/ou rápida dissipação do calor. (65)

Também foi registrado o caso particular de uma lesão do tipo melanoma em uma paciente albina (Figura 22). Em pacientes nesta condição, a lesão não apresenta qualquer pigmentação, e mesmo neste caso também foi verificada menor temperatura da lesão. Esta observação sugere que a diminuição na emissão do infravermelho é característica deste tipo de lesão, independentemente de sua pigmentação.

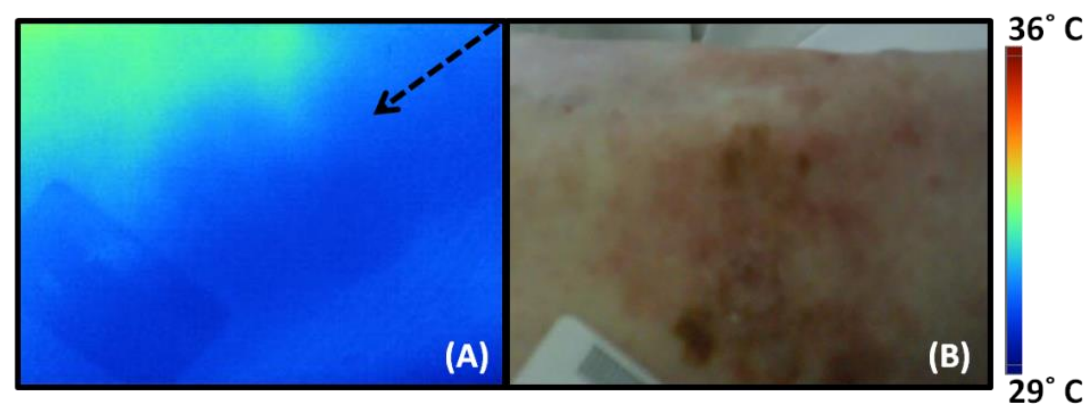

Figura 22 - Imagens de infravermelho (A) e de luz branca (B) de uma lesão de melanoma sem pigmentação em uma paciente albina.

Fonte: Elaborada pela autora.

Uma característica interessante das lesões do melanoma é que, apesar de verificadas temperaturas menores que as do entorno em lesões cutâneas, também foram registradas 6 lesões subcutâneas metastáticas. O diagnóstico para este tipo de lesão geralmente é realizado por tomografia por emissão de pósitrons/tomografia computadorizada (PET/CT), técnica que exige do paciente permanecer em repouso por 1 hora antes do procedimento, ficar imóvel pelo tempo de 25 a 40 minutos durante o exame, dieta esecífica por $24 \mathrm{~h}$ antecedentes ao exame e ingestão de radiofármaco. 
(66-68) Estes fatores trazem desconforto ao paciente. Além disso, a técnica envolve alto custo e não é portátil, causando difícil acesso a grande parte dos pacientes.

Estas lesões apresentaram maiores temperaturas com relação ao tecido adjacente (Figura 23), diferente das lesões cutâneas. Isto poderia ser justificado pelo fato de que a localização subcutânea possibilitaria uma maior vascularização ao redor da lesão. Além disso, existe também o fato de que, por ser uma lesão de alta atividade metabólica que fica inserida no tecido subcutâneo, o qual possui baixa condutividade térmica $\left(0,19 \mathrm{~W} / \mathrm{m}^{\circ} \mathrm{C}\right)$, há menor perda de calor para o ambiente por condução, o que não ocorre com as lesões localizadas na derme, cuja maior condutividade térmica $\left(0,45 \mathrm{~W} / \mathrm{m}^{\circ} \mathrm{C}\right)$ permite a dissipação local de calor com maior facilidade. (69)

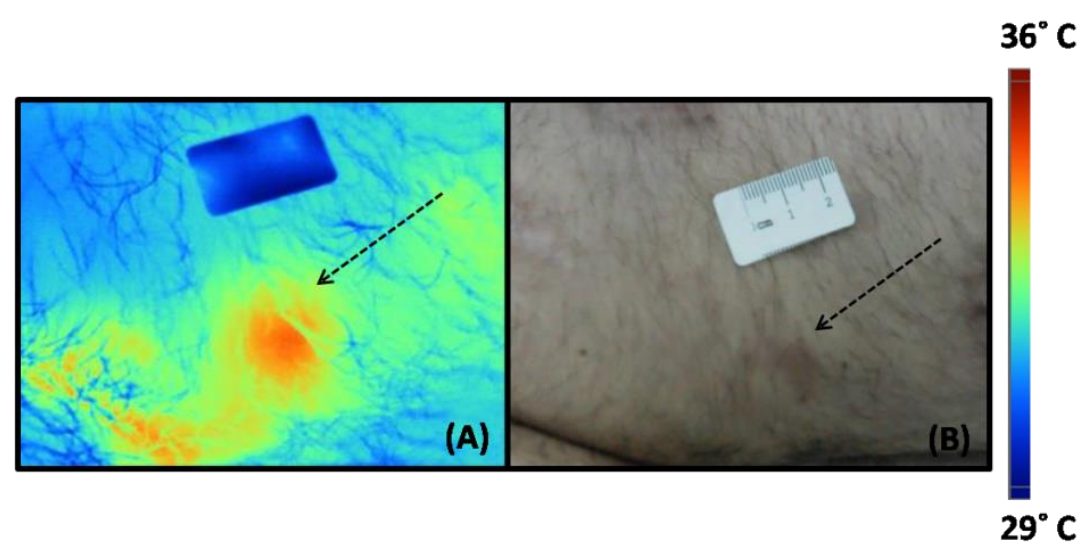

Figura 23 - Imagens de infravermelho (A) e de luz branca (B) de uma lesão de melanoma subcutânea.

Fonte: Elaborada pela autora

Selecionando uma imagem típica de lesão de melanoma, outros aspectos puderam ser explorados na Figura 24. 


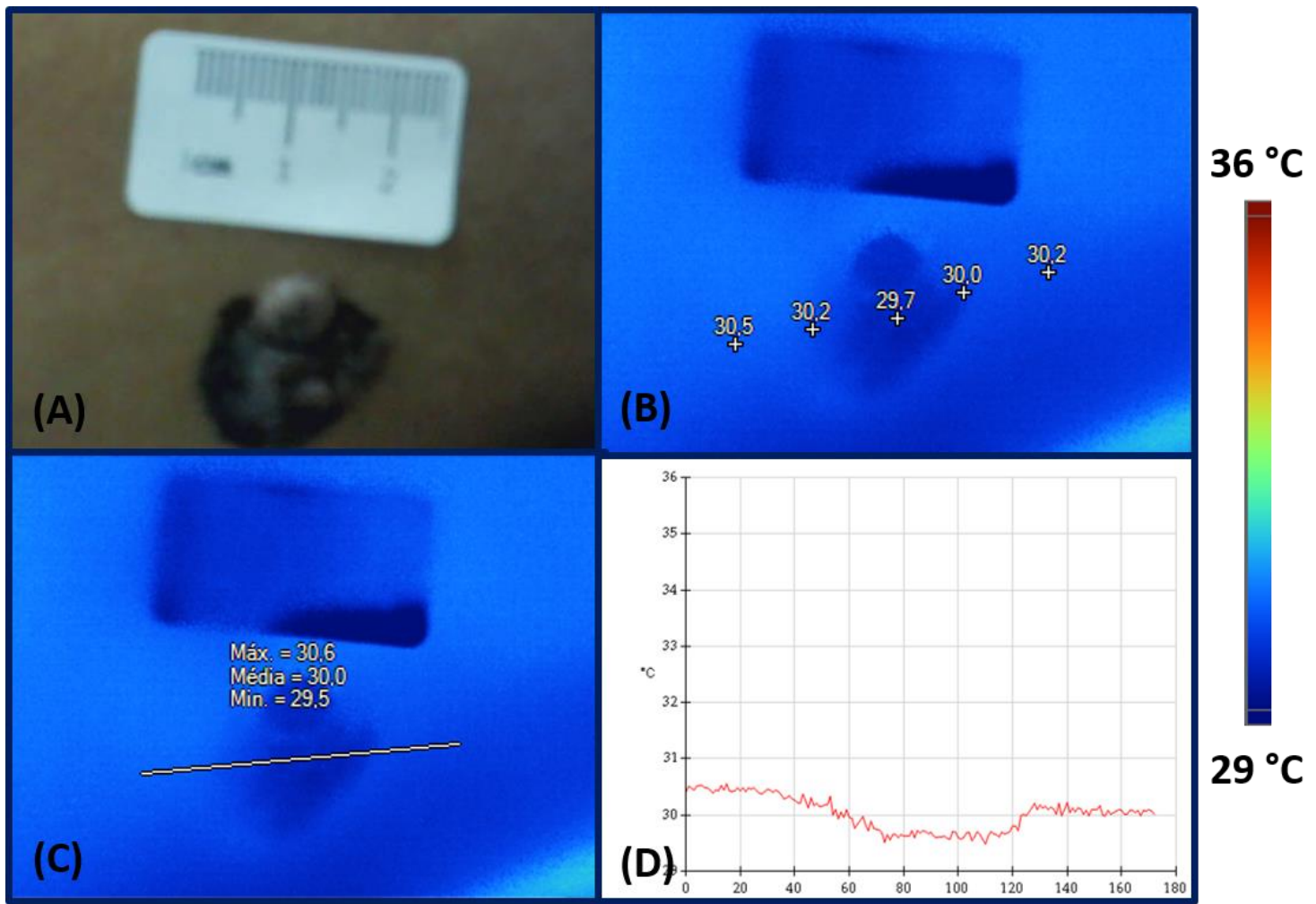

Figura 24 - (A) Imagem de luz branca de uma lesão do tipo melanoma, (B) imagem de infravermelho da lesão com valores de temperatura em alguns pontos da imagem, (C) reta traçada cortando o centro da lesão, e (D) seu respectivo gráfico de temperatura em função dos pixels da imagem. A barra lateral à direita indica a escala de temperatura compreendida nas imagens $(B)$ e $(C)$.

Fonte: Elaborada pela autora.

Podemos observar na Figura 24 B que a lesão em si apresenta valores de temperatura menor, em torno de $29,7^{\circ} \mathrm{C}$, enquanto o tecido ao redor apresenta valores de 30,5 e $30,2^{\circ} \mathrm{C}$. Além disso, verificamos que as temperaturas nas bordas da lesão - entre 30,2 e $30,0{ }^{\circ} \mathrm{C}$ - pouco diferem da região ao redor, justificando a reduzida capacidade de delimitação das bordas da lesão nas imagens térmicas.

Através do segmento de reta que atravessa a lesão (Figura $24 \mathrm{C}$ ) e seu respectivo gráfico da variação de temperatura em função dos pixels da imagem (Figura $24 \mathrm{D}$ ), podemos observar que, nas regiões sadias, o tecido possui uma temperatura praticamente constante, em torno de $30,5^{\circ} \mathrm{C}$, que decai ao passar pela borda da lesão (em torno de $60^{\circ}$ pixel), até que a temperatura chega ao valor mínimo de aproximadamente $29,7{ }^{\circ} \mathrm{C}$ no interior da lesão. Ao atravessar a lesão, a temperatura volta a aumentar na fronteira do tecido normal (próximo do $120^{\circ}$ pixel) apresentando uma temperatura média de $30,1^{\circ} \mathrm{C}$. 
As lesões do tipo QSP, que são alterações benignas, apresentam temperatura ainda menor que a região circundante e melhor definição das bordas para a maior parte das lesões (67\% das lesões registradas) se comparadas com lesões do tipo melanoma, como se pode observar na Figura 25. As demais lesões ou estavam em regiões com presença de pelos ou eram muito pequenas e pouco nodulares, fazendo com que estas lesões tivessem suas bordas pouco evidenciadas nas imagens.

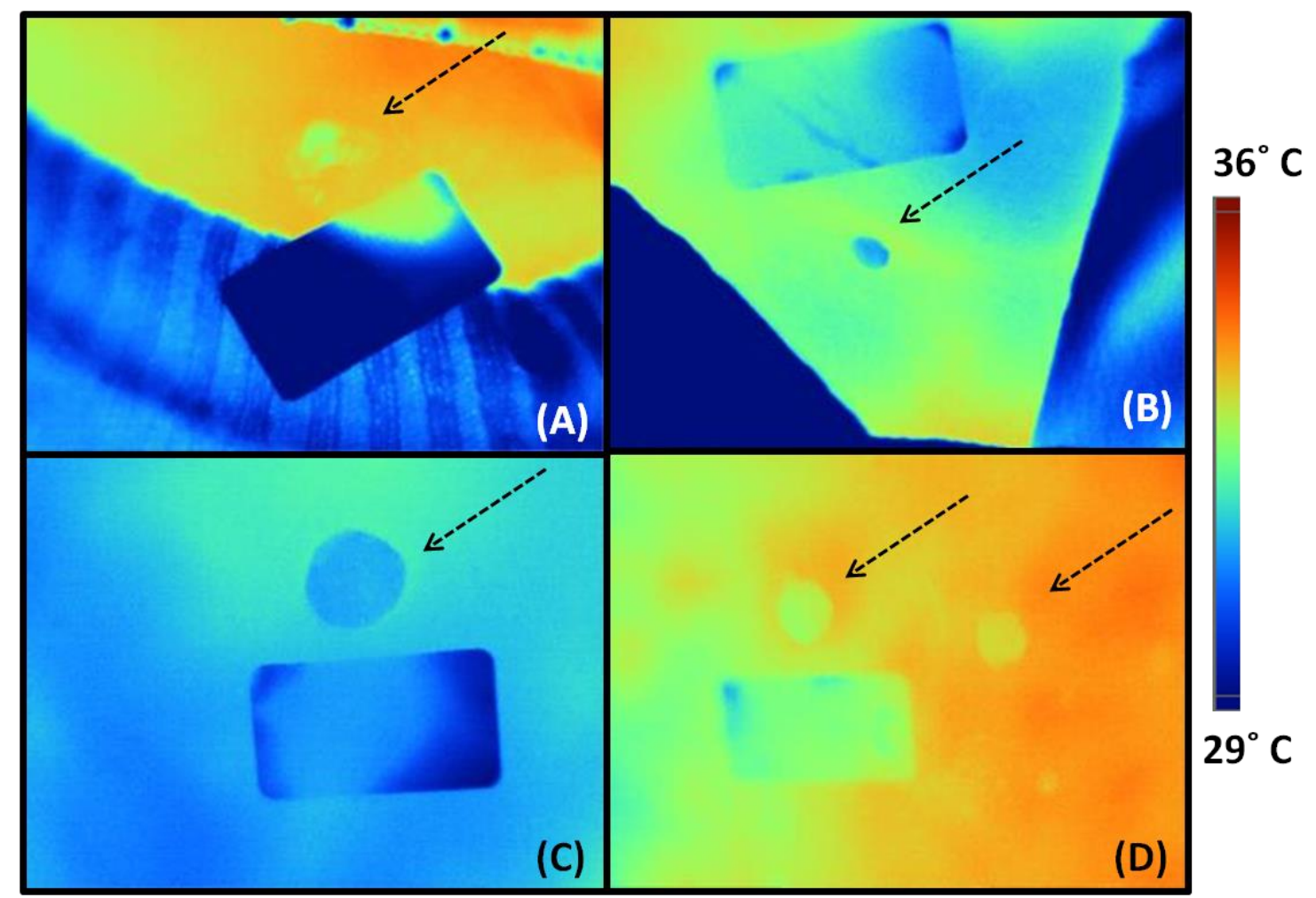

Figura 25 - Imagens termográficas de lesões do tipo QSP. Fonte: Elaborada pela autora

Selecionando uma lesão do tipo QSP, analisamos outras características na Figura 26. 


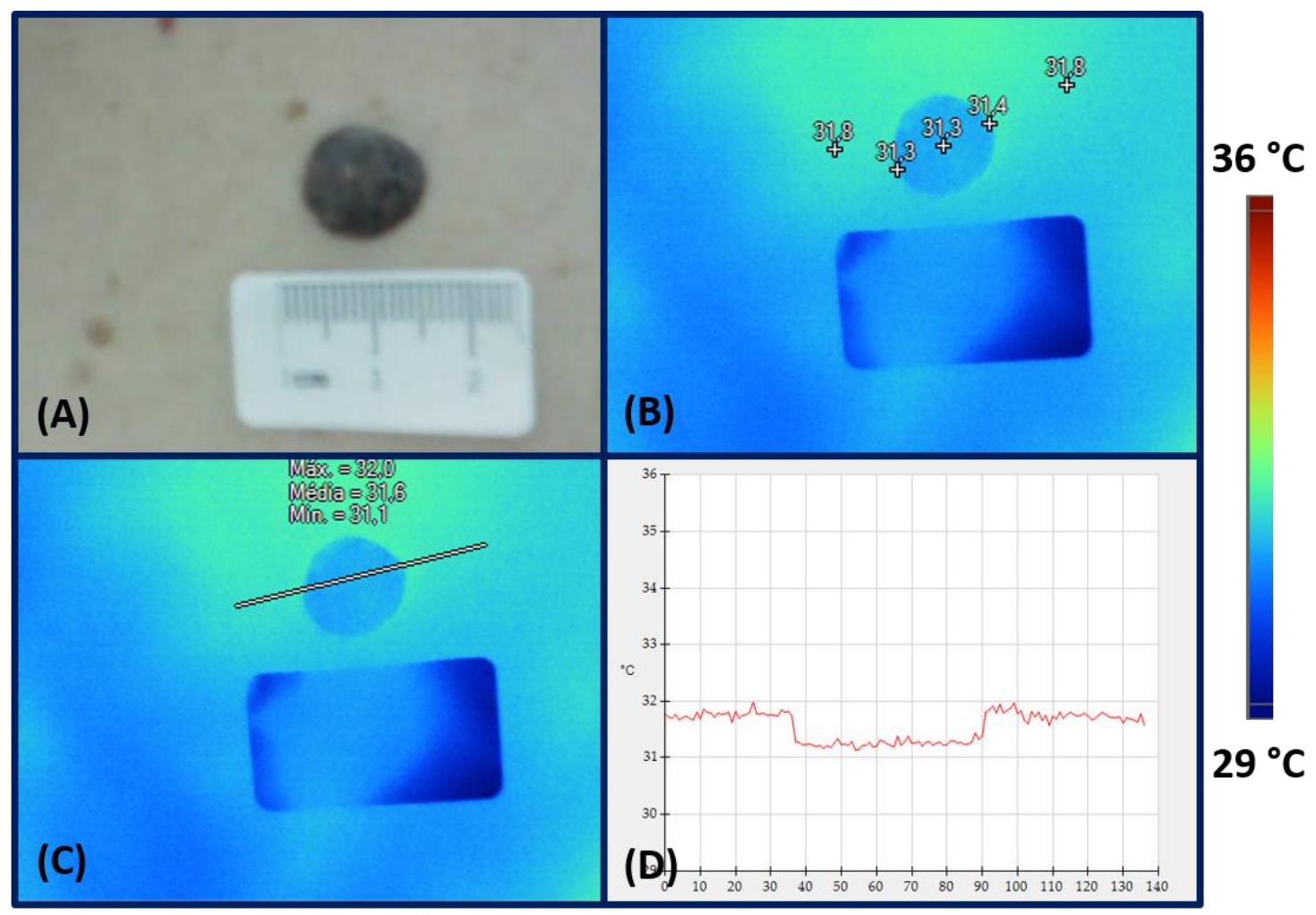

Figura 26 - (A) Imagem de luz branca de uma lesão do tipo melanoma, (B) imagem de infravermelho da lesão com valores de temperatura em alguns pontos da imagem, (C) reta traçada cortando o centro da lesão, e (D) seu respectivo gráfico de temperatura em função dos pixels da imagem. A barra lateral à direita indica a escala de temperatura compreendida nas imagens $(B)$ e $(C)$.

Fonte: Elaborada pela autora

Na Figura 26 B, é possível observar que a lesão apresenta valores de temperatura menores que o seu entorno, ficando em torno de $31,3^{\circ} \mathrm{C}$, em contraste aos $31,8^{\circ} \mathrm{C}$ do tecido ao redor. Também se verificou que as temperaturas nas bordas da lesão possuem valores de 31,3 e $31,4{ }^{\circ} \mathrm{C}$, valores semelhantes aos das temperaturas presentes na parte interna da lesão, que diferem daqueles do tecido imediatamente ao redor da lesão, justificando a boa delimitação das bordas.

No gráfico da variação de temperatura em função dos pixels da imagem (Figura 26 D), obtido através do segmento de reta traçado sobre a lesão (Figura 26 C), podemos observar que nas regiões fora da lesão o tecido possui uma temperatura

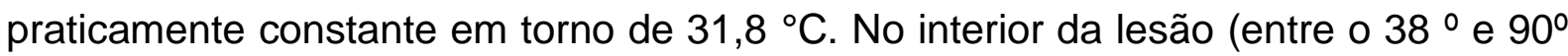
pixel), a temperatura diminui para aproximadamente $31,2^{\circ} \mathrm{C}$, com variações abruptas nas periferias da lesão, evidenciando novamente a delimitação bastante clara das bordas observadas nas imagens térmicas de QSP, particularmente quando comparadas com as lesões do tipo melanoma. 


\subsubsection{Análise das médias de temperatura}

Para a análise da média de temperatura das imagens das diversas lesões, foi utilizada a mesma rotina descrita nas análises das imagens em animais (sessão 5.1). Foi realizada seleção manual na imagem do contorno da lesão (a imagem de luz branca foi usada como referência para a delimitação do contorno da lesão sempre que este contorno não se mostrou bem definido na termografia) e de outra região fora desta, ao seu redor, de modo a obter os valores médios de temperatura e seus respectivos desvios padrão em ambas as regiões. Com os valores obtidos em cada imagem, a média para cada tipo de lesão foi calculada, bem como a diferença entre

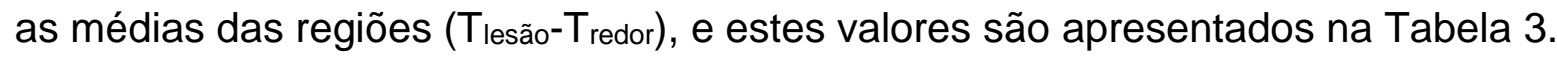

Tabela 3 - Variação da temperatura média das lesões nas regiões interior e circundante à lesão. "Diferença" representa a diferença média entre as temperaturas da lesão e de seu entorno.

\begin{tabular}{cccc}
\hline Lesões & $\begin{array}{c}\text { T lesão } \\
\left({ }^{\circ} \mathbf{C}\right)\end{array}$ & $\begin{array}{c}\text { T redor } \\
\left({ }^{\circ} \mathbf{C}\right)\end{array}$ & $\begin{array}{c}\text { Diferença } \\
\left({ }^{\circ} \mathbf{C}\right)\end{array}$ \\
\hline $\begin{array}{c}(32,2 \pm 0,2) \\
\text { CBC nodular }\end{array}$ & $(32,7 \pm 0,3)$ & $(-0,5 \pm 0,6)$ \\
Nevo Intradérmico & $(32,3 \pm 0,2)$ & $(32,7 \pm 0,2)$ & $(-0,3 \pm 0,3)$ \\
\hline QA & $(32,0 \pm 0,2)$ & $(32,1 \pm 0,3)$ & $(-0,1 \pm 0,4)$ \\
CEC & $(33,6 \pm 0,4)$ & $(33,0 \pm 0,4)$ & $(0,6 \pm 0,8)$ \\
\hline QSP & $(32,6 \pm 0,2)$ & $(32,9 \pm 0,2)$ & $(-0,3 \pm 0,4)$ \\
Melanoma & $(31,4 \pm 0,2)$ & $(31,7 \pm 0,4)$ & $(-0,2 \pm 0,6)$
\end{tabular}

Fonte: Elaborada pela autora

$\mathrm{Na}$ Tabela 3, observa-se que as variações médias de temperatura das lesões obtidas pelos processamentos foram insuficientes para diferenciar lesões clinicamente semelhantes, devido aos valores de desvios encontrados serem da mesma ordem das diferenças médias de temperatura. Podemos observar que, de maneira condizente com o que foi visto nas imagens apresentadas, o par de lesões CEC $\times$ QA foi o que mais apresentou diferença em seu valor médio de temperatura, embora seus valores de desvio ainda se sobreponham a estas diferenças. 
Esta insignificante diferença entre as diferenças de temperatura médias podem ser relacionados a vários fatores, como a presença de ulceração presente em várias lesões malignas e pré-malignas, o que aumenta a heterogeneidade da temperatura no interior da lesão, ou o fato de que parte das lesões possuem bordas pouco definidas nas imagens termográficas, dificultando a determinação exata das bordas da lesão e, portanto, aumentando a chance de que as médias sofressem interferência indevida de regiões adjacentes. Além disso, existem fatores naturais que causam diferenças nestas temperaturas como presença de pelos ou de vaso calibroso na região, os diferentes sítios anatômicos em que as lesões estão localizadas e variações intrínsecas entre cada paciente. Regiões pouco vascularizadas, com nariz e orelha, apresentam baixas temperaturas e dificultam a detecção de lesões que apresentam baixas temperaturas.

Os gráficos de temperatura em função dos pixels da imagem quando tracejada uma linha que atravessa o centro da lesão (como das Figuras 14 D, 16 D, 18 D, 20 D, 24 D e 26 D), assim como suas derivadas, também foram utilizados na tentativa de discriminação das lesões clinicamente semelhantes. Porém, novamente as diversas heterogeneidades presentes nas imagens impossibilitaram que fosse encontrado um padrão que discriminasse os pares de lesões.

\subsubsection{Análise dos atributos das imagens}

Foi elaborada uma rotina em MATLAB que calculava várias métricas (mostradas na Tabela 2) de cada imagem térmica. Na sequência, a partir do software Weka, o classificador MVS foi utilizado para avaliar a capacidade de discriminação das imagens a partir dos valores das métricas, a matriz de confusão obtida para cada par de lesão CBC vs NI, CEC vs QA e melanoma vs QSP, estão apresentados na Figura 27. 

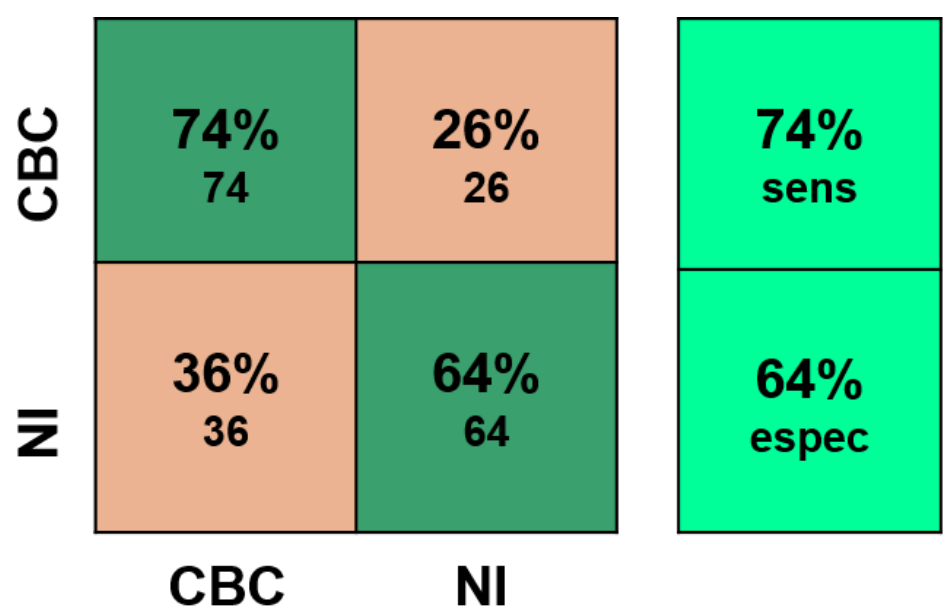

(A)
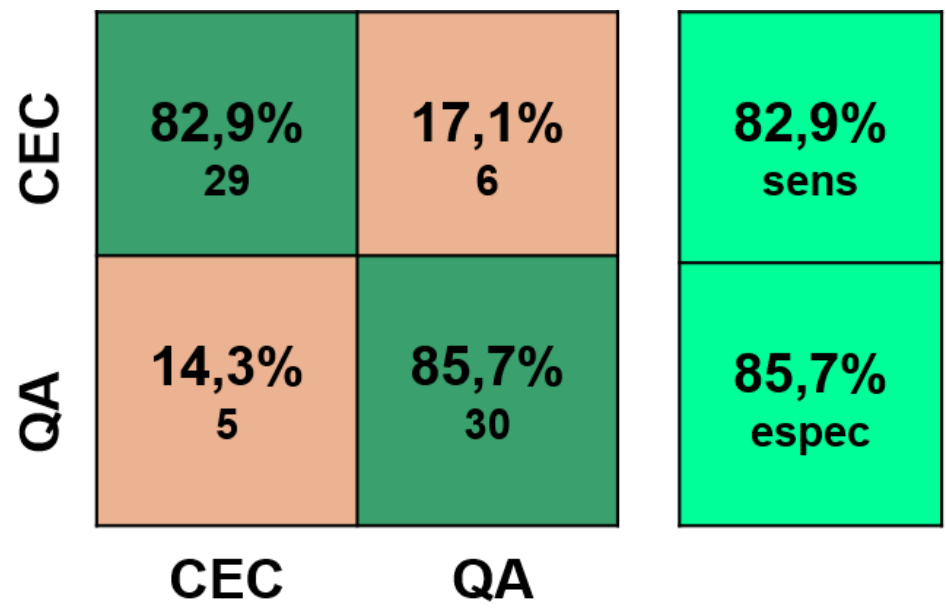

(B)

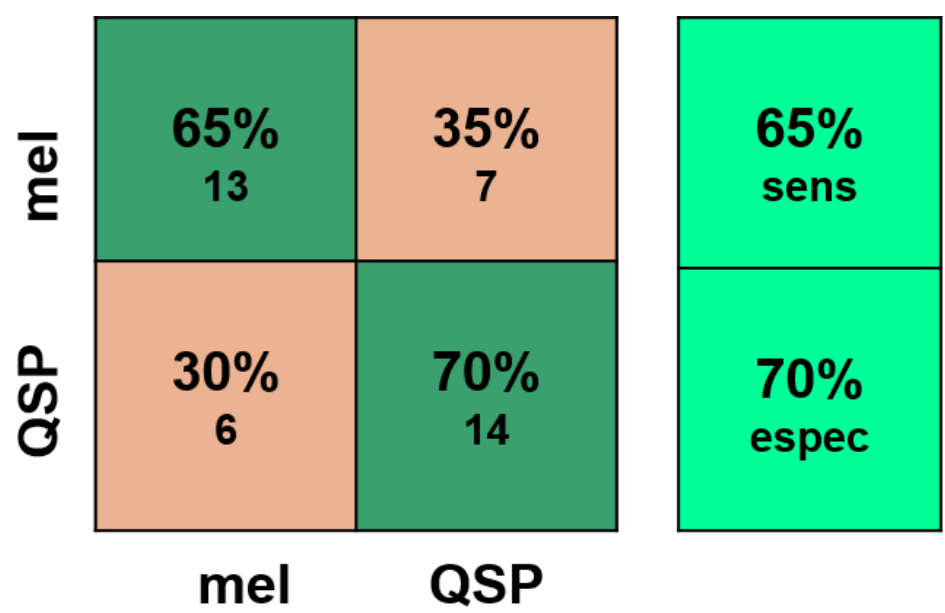

(C)

Figura 27 - Matriz de confusão obtida pelo classificador SVM usando o software Weka para os pares (a) BCV vs $\mathrm{NI}$; (B) CEC vs QA e (c) melanoma vs QSP. As linhas mostram o tipo de lesão que é e as colunas mostram o tipo que a lesão foi classificada. Os números verdes na coluna da esquerda mostram a sensibilidade (linha superior) e a especificidade (linha inferior).

Fonte: Elaborada pela autora 
A sensibilidade reflete o quanto o método é eficaz de identificar corretamente, as lesões avaliadas, aqueles que realmente apresentam a característica de interesse, no caso as lesões neoplásicas. Já a especificidade de um método reflete o quanto ele é eficaz de identificar corretamente os indivíduos que não apresentam a condição de interesse, as não neoplásicas neste caso. Sensibilidade e especificidade mostram melhor poder de discriminação quando se chegam mais próximo de 1, ou seja, $100 \%$.

Os resultados mostram uma grande capacidade de discriminação de lesões clinicamente semelhantes, principalmente na discriminação entre o par de lesão CEC vs QA (82,9\% de sensibilidade e $85,7 \%$ de especificidade), para o qual já se podia notar maior diferença visual nas imagens. Como discutido anteriormente, muitas vezes lesões de CEC podem surgir como evolução de uma $Q A$, e as duas variedades de lesão podem estar simultaneamente presentes na mesma região, tendo um difícil diagnóstico pela dermatoscopia. (64) Por isso, é importante reiterar a importância que a capacidade de distinção entre estas duas lesões apresenta.

O melanoma vs QSP foi o par de lesões com menor discriminação (65\% de sensibilidade e $70 \%$ de especificidade), mas os resultados foram bastante satisfatórios, com a maioria das lesões classificadas corretamente em ambos os tipos. É importante notar, que para este par de lesões, foram coletadas apenas 20 lesões de cada tipo (por motivos de casuística, ou seja, baixa ocorrência de melanoma), e este fato provavelmente impede que os testes realizados alcancem melhores resultados para discriminar as lesões. Além de que a baixa incidência fez com que não ouvesse critério de seleção para estas lesões registradas, ou seja, foram incluídas tanto lesões extensas quanto lesões nodulares no estudo, esta falta de homogeneidade entre as amostras também favorece no menor índice de discriminação. Acreditamos que com maior número de lesões e consequente aumento do espaço amostral com critério de seleção do grupo poderia otimizar o poder de discriminação para este par de lesões. Além disso, os melanomas cutâneos que foram registrados tratam-se de tumores primários e pequenos, características de um melanoma que não apresenta aumento de temperatura devido sua baixa angiogênese. (65)

A Figura 28 mostra as curvas de Característica Operacional do Receptor (COR) dos pares de lesões, que mostram a variação da "Taxa de positivo verdadeiro" contra a "Taxa de falso positivo". 


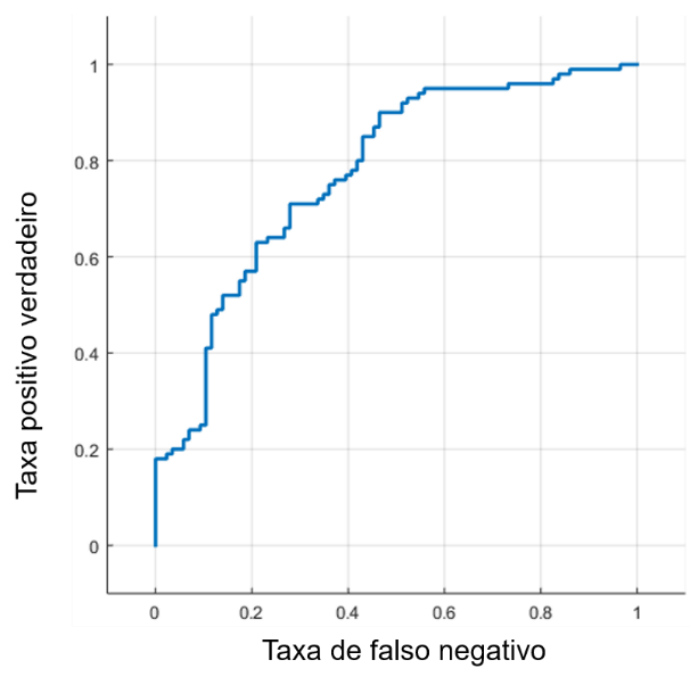

(A)

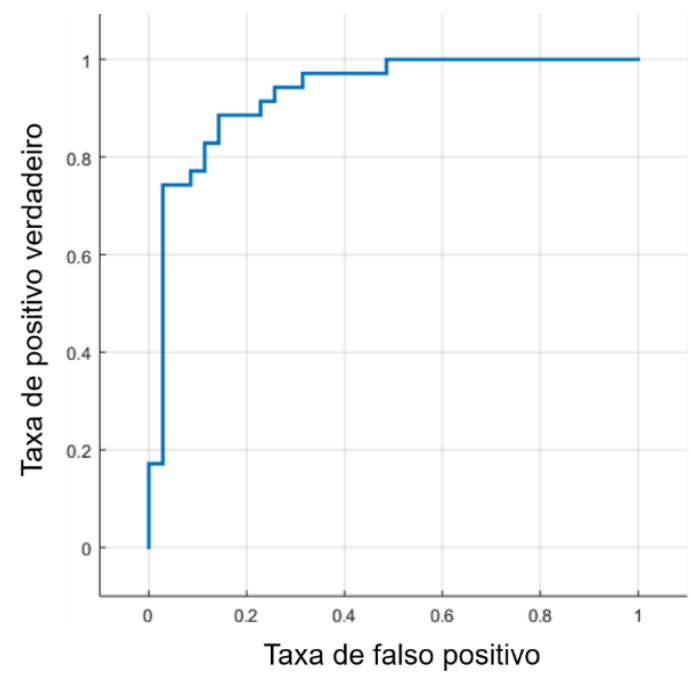

(B)

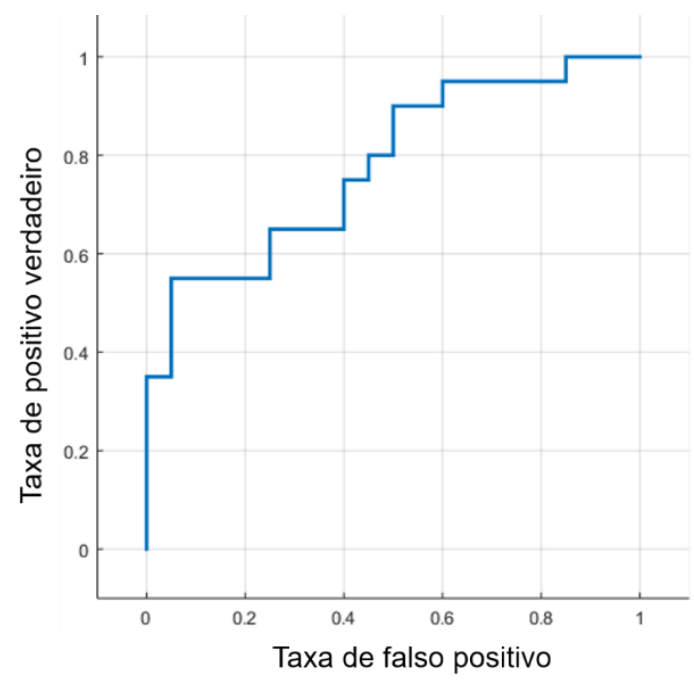

(C)

Figura 28 - Curvas COR obtidas pelo classificador MVS usando o software Weka para os pares (a) CBC vs NI; (B) CEC vs QA e (c) melanoma vs QSP.

Fonte: Elaborada pela autora

Novamente, o CEC vs QA mostrou maior discriminação, já que sua "Taxa de positivo verdadeiro" cresce mais rapidamente que nas demais curvas. Os pares CBC vs $\mathrm{NI}$ e melanoma vs QSP demonstraram ter um crescimento semelhante de suas "Taxas de positivo verdadeiro", mostrando que o método possui habilidades de discriminação semelhantes para ambas as lesões. A curva de melanoma vs QSP 
apresenta uma curva menos homogênea, com maior presença de degraus, devido ao menor número de lesões analisadas para estes tipos.

Os resultados obtidos através deste método sugerem que a termografia, associada a um software de processamento adequado das imagens, pode ser usada como ferramenta de auxílio a médicos no diagnóstico acurado de lesões da pele. Com isso, a utilização da dermatoscopia e da termografia de maneira conjunta podem melhorar o resultado individual de cada técnica na discriminação destes tipos de lesões. Além de que, a utilização da termografia na detecção de melanomas subcutâneos podem auxiliar o médico tanto na localização destas lesões para que seja feita a remoção cirúrgica quanto possibilitando que se faça um monitoramento destas lesões quando tratadas com quimioterapia.

\subsubsection{Avaliação da resposta da TFD}

\subsubsection{Monitoramento da TFD utilizando termografia}

O tratamento de 40 lesões do tipo CBC com TFD foi registrado por termografia. Imagens foram coletadas em diferentes fases das duas sessões do tratamento (lesão inicial, após o tempo de incubação do medicamento e imediatamente após a iluminação).

$\mathrm{Na}$ Figura 29 são mostradas as imagens de termografia durante as duas sessões de TFD em um CBC nodular de 0,64 x 0,75 cm na região dorsal direita. 


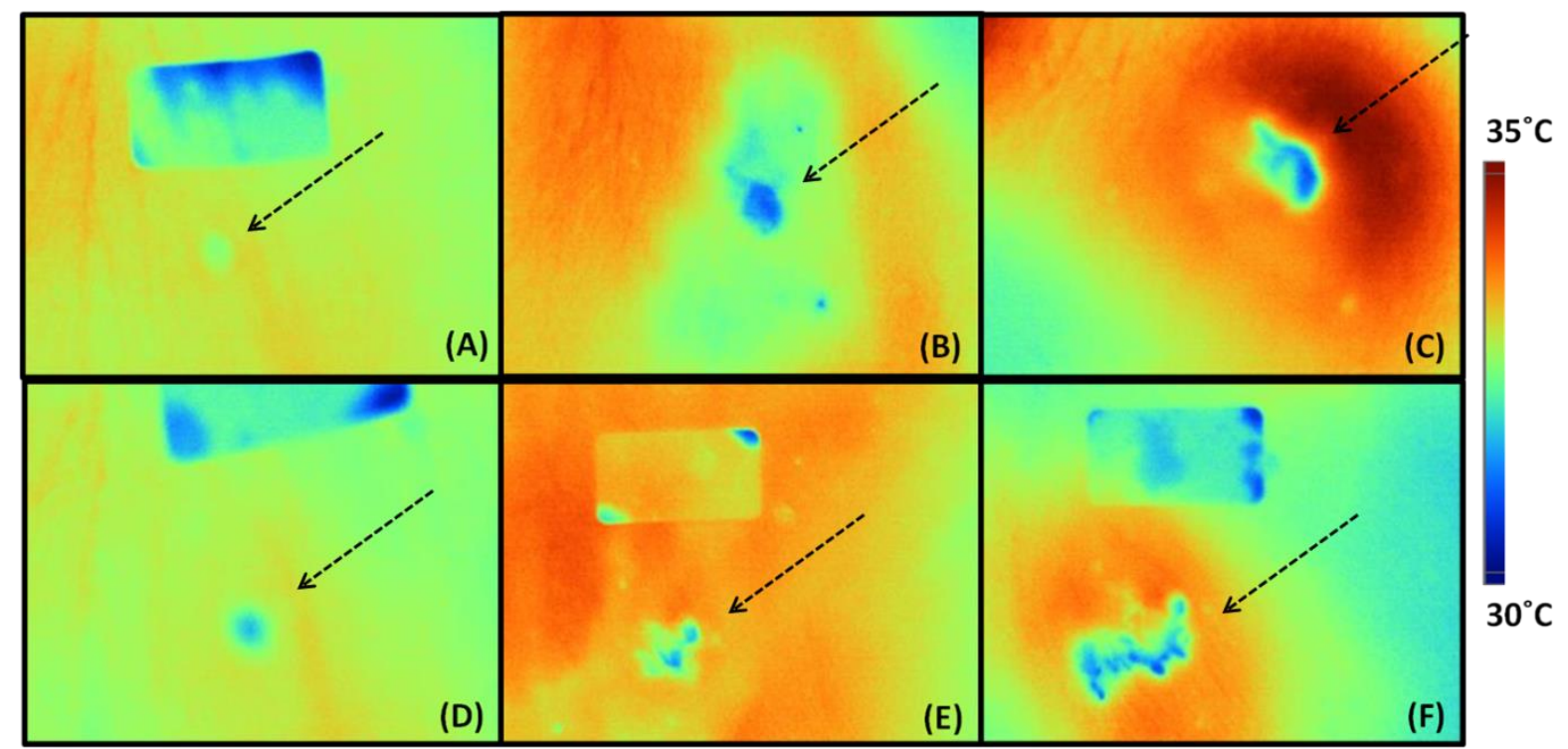

Figura 29 - Imagem de termografia de CBC nodular: (A) inicial (1ª sessão), (B) após a incubação da

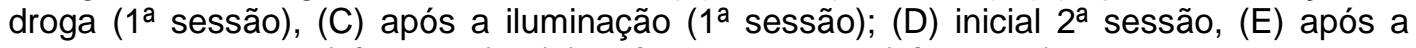
incubação da droga (2 $2^{\underline{a}}$ sessão) e (F) após a iluminação (2ª sessão).

Fonte: Elaborada pela autora

Na Figura 30 são mostradas as imagens térmicas durante as duas sessões de TFD em um CBC superficial de 1,86 x 1,85 cm na região interescapular.

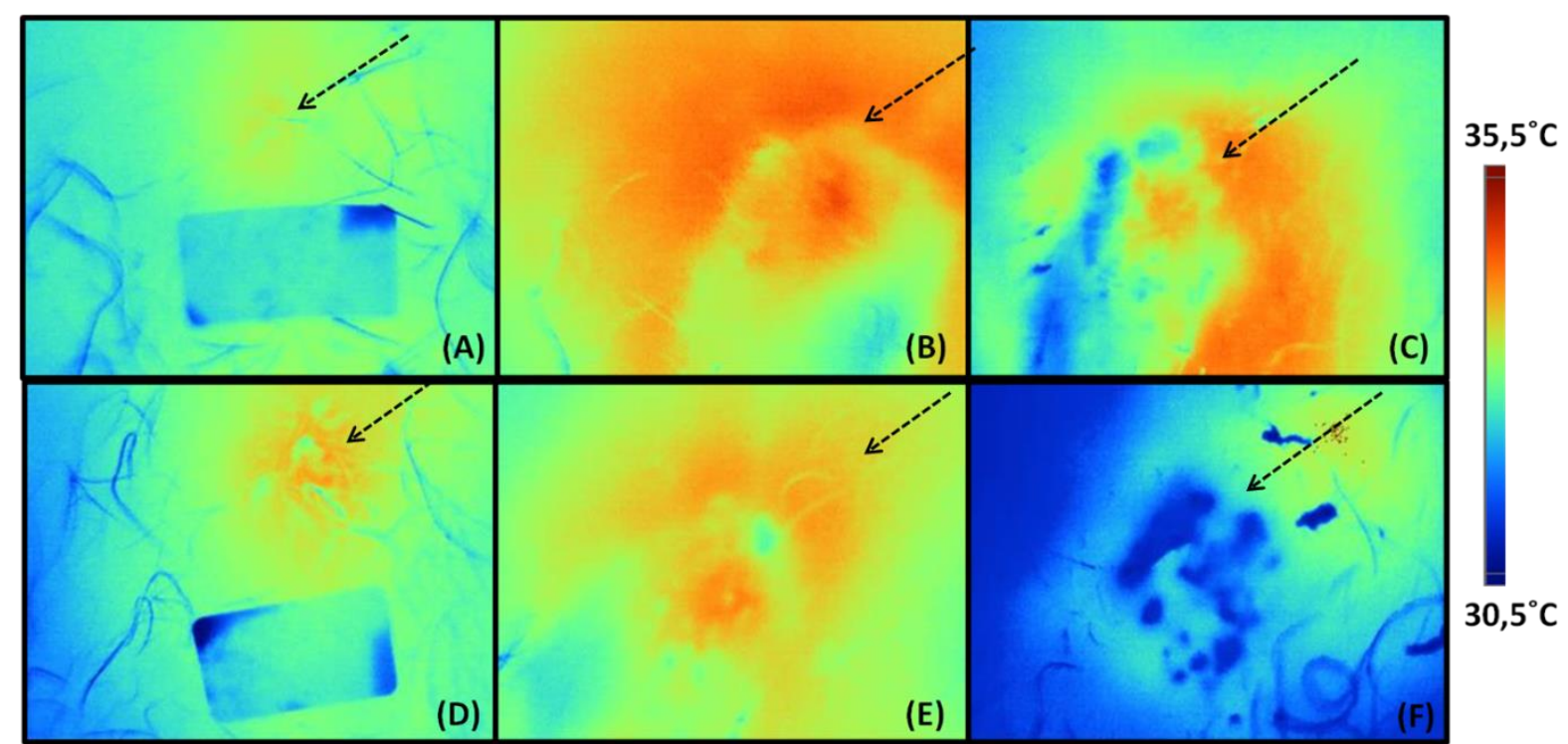

Figura 30 - Imagem de termografia de CBC superficial (A) inicial, (B) após a incubação da droga e (C) após a iluminação durante a primeira sessão; e (D) inicial, (E) após a incubação da droga e (F) após a iluminação durante a segunda sessão.

Fonte: Elaborada pela autora

Em ambos os casos verifica-se, pelas imagens, que o tecido sadio ao redor da lesão apresenta maior aumento da temperatura durante as duas sessões da TFD (quadros C e F das Figuras 29 e 30) do que o tecido da própria lesão, confirmando o que já foi descrito na literatura. (63) Com base nas observações decorrentes deste 
estudo e dos relatos da literatura, a razão mais provável para que isso ocorra relaciona-se ao fato de que, durante a iluminação, a região tumoral consome maior parte da luz no processo da TFD, fazendo com que menos luz seja convertida em calor, enquanto na região sadia, por haver menor concentração de FS, há maior produção de calor resultante da absorção de luz por outras biomoléculas que não as de FS. Além disso, a circulação sanguínea do tecido adjacente ao irradiado tende a dissipar o calor produzido no local e, portanto, é natural que parte importante do calor seja detectada nas adjacências da lesão iluminada.

Como se vê na Figura 30, para a maior parte das imagens que retratam a TFD de $C B C$ superficiais, as lesões apresentaram temperatura maior que o tecido ao redor no início da segunda sessão, ao contrário das lesões nodulares. É provável que isto ocorra por uma maior efetividade da TFD neste caso, pois tais lesões possuem menor espessura de tecido tumoral (que, como visto para os resultados de $\mathrm{CBC}$ nodular, apresenta menor temperatura se comparado ao tecido normal). Isso, somado ao processo inflamatório decorrente da terapia - que eleva a temperatura na região, e que perdura por um intervalo de tempo variável, mas que muitas vezes alcança o período da segunda aplicação - muito provavelmente explica a maior temperatura observada nestes casos.

\subsubsection{Comparação da termografia com imagens de fluorescência}

Além do registro termográfico, imagens de fluorescência das lesões após 3 horas de incubação com Metil-ALA também foram registradas, evidenciando assim, a área de formação da PpIX. A Figura 31, mostra a alteração térmica e a imagem de fluorescência da formação de PpIX de uma das lesões, comparando primeira e segunda sessão de TFD. 


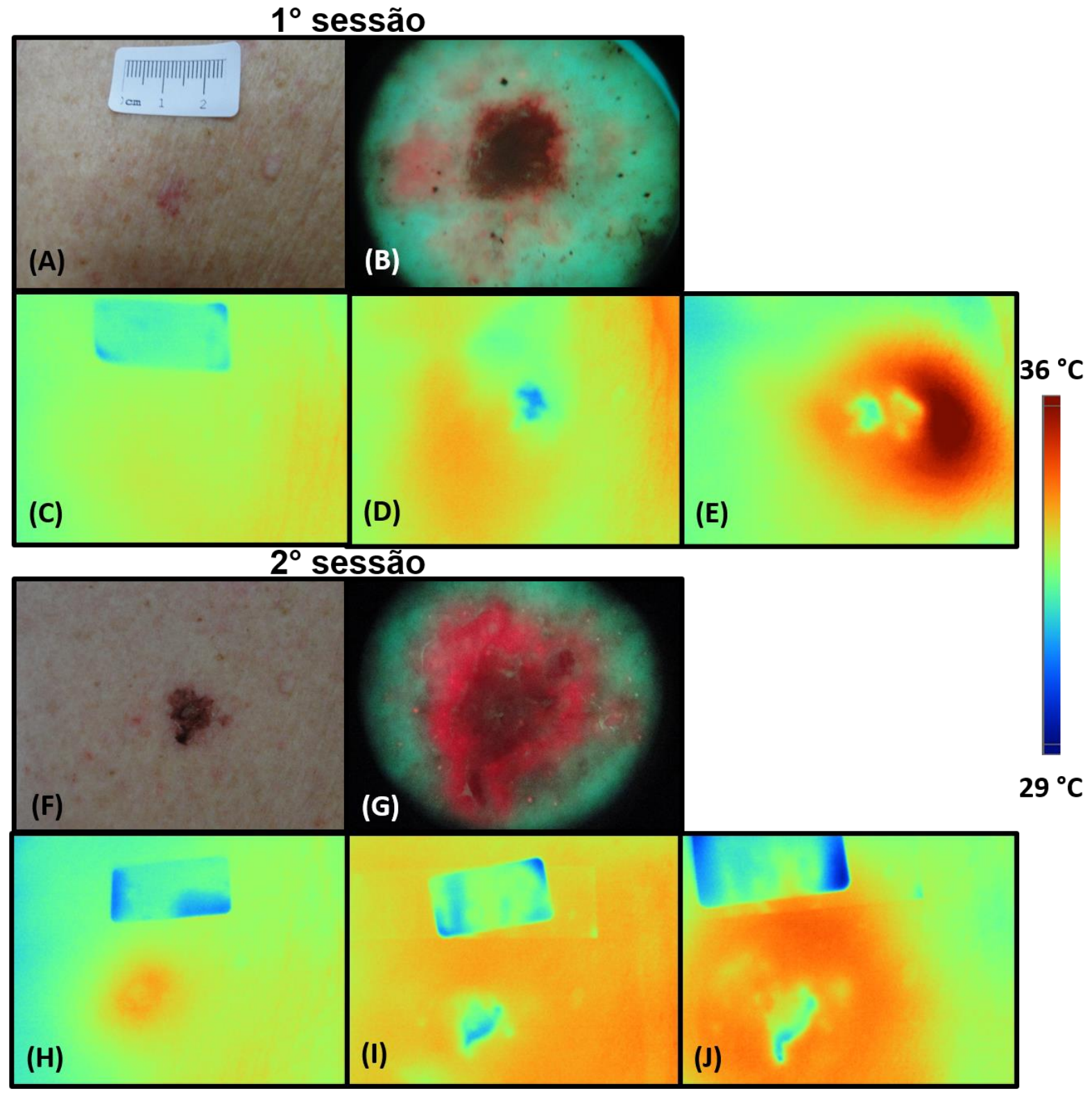

Figura 31 - Durante a primeira sessão: (A) imagem de luz branca da lesão no início do tratamento, (B) imagem de fluorescência após incubação do Metil-ALA, imagens de termografia (C) da lesão inicial, (D) após a incubação, (E) após a iluminação; durante a segunda sessão: (F) imagem de luz branca da lesão no início do tratamento, $(G)$ imagem de fluorescência após incubação do Metil-ALA, imagens de termografia $(H)$ da lesão inicial, (I) após a incubação, $(\mathrm{J})$ após a iluminação.

Fonte: Elaborada pela autora.

É possível observar que a lesão original é pouco evidenciada na imagem de termografia (Figura $31 \mathrm{C}$ ). Isto poderia ser esperado, visto que o protocolo de tratamento previa limitação do tamanho das lesões a serem tratadas (no máximo 3 $\mathrm{mm}$ de profundidade, portanto de pequeno volume). No decorrer do tratamento, a lesão torna-se mais evidente nas imagens termográficas. Após a incubação por 3 horas com Metil-ALA (Figuras $31 \mathrm{D}$ e I) a lesão mostra-se como uma região mais fria 
que o tecido adjacente, e essa diferença de temperatura torna-se mais evidente após a iluminação (Figuras $31 \mathrm{E}$ e J). Das imagens de fluorescência (Figuras $31 \mathrm{~B}$ e G), nota-se que a formação de PPIX foi mais intensa na segunda sessão (Figura $31 \mathrm{G}$ ), onde vê-se uma maior intensidade de luz vermelha emitida. De modo geral, observouse que quanto maior fluorescência da PpIX observada, maior foi o contraste observado entre tecido da lesão e região ao redor via imagens de termografia.

Além disso, é possível observar pela imagem de fluorescência que, na primeira sessão -onde a formação da PpIX foi mais seletiva e localizada na região da lesão (Figura 31 B) - verificou-se também uma melhor delimitação das bordas da lesão nas imagens térmicas após a realização da iluminação do tratamento (Figura $31 \mathrm{E}$ ). Na segunda sessão, quando espera-se um menor volume de células tumorais (devido a morte celular induzida via TFD na primeira sessão), a formação de PpIX é menos seletiva, e não se restringe tanto à região inicial da lesão (Figura $31 \mathrm{G}$ ), enquanto a delimitação das bordas da lesão também fica menos evidente nas imagens térmicas após o fim da iluminação (Figura $31 \mathrm{~J}$ ). Com esta e as demais lesões analisadas, é possível afirmar que existe uma correlação entre a fluorescência da PpIX evidenciada durante o tratamento e o gradiente de temperatura das imagens térmicas após a TFD (que delimita as bordas das lesões).

Os resultados obtidos neste trabalho indicam que a termografia é uma ferramenta capaz de confirmar a seletividade da TFD. Foi possível observar, através da termografia, que ocorreu menor seletividade da TFD na segunda sessão, o que é esperado uma vez que a quantidade de células tumorais remanescentes deve ser menor após um primeiro tratamento. A seletividade observada mostrou-se mais evidente nas imagens após a iluminação e menos evidente após o procedimento de incubação do Metil-ALA.

Como mostram as Figuras $31 \mathrm{~B}$ e G, fica evidente a grande seletividade na formação da PpIX, bem como a eficiente delimitação das bordas da lesão nas imagens térmicas ao fim da primeira de sessão; na segunda sessão, por outro lado, a seletividade de PpIX e a delimitação das bordas mostraram-se menos evidenciadas. Dentre as 40 lesões que tiveram seus procedimentos monitorados tanto por termografia quanto por imagens de fluorescência, esse comportamento reproduziu-se em 21 dos casos. Dentre os casos em que não se observou esse padrão, em 9 das lesões, houve problemas na coleta de algumas das imagens, principalmente pela dificuldade em conseguir obter foco na imagem registrada, resultante da anatomia do 
sítio anatômico onde se localizava a lesão. As demais 10 lesões apresentaram exceções desses comportamentos que não puderam ser justificadas, exceto talvez pela presença de pouco tecido tumoral na região, tornando tais lesões menos sensíveis à seletividade do procedimento.

\subsubsection{Cálculo das médias de temperatura dentro e fora da região da lesão durante a TFD}

Para a análise das imagens registradas durante a TFD, foi utilizada a rotina para o cálculo da média de temperatura nas regiões delimitadas, descrita em 4.4.1. Neste caso, obteve-se o valor médio de temperatura com o respectivo desvio padrão tanto na região da lesão quanto na região ao redor dela. Das 40 lesões tratadas, 36 lesões tiveram resposta completa ao tratamento e 4 delas apresentaram resposta incompleta. Foram consideradas lesões com resposta completa as que apresentaram remossão total da lesão após o procedimento de TFD por exame clínico e histopatológico. As lesões com resposta incompleta foram as que apresentaram lesão residual pelo mesmo critério de análise.

Com os valores médios de temperatura calculados, foi possível verificar o quanto a temperatura da lesão variou durante o procedimento em relação ao tecido sadio, nos dois tipos de respostas ao tratamento, como pode ser visto no gráfico da Figura 32.

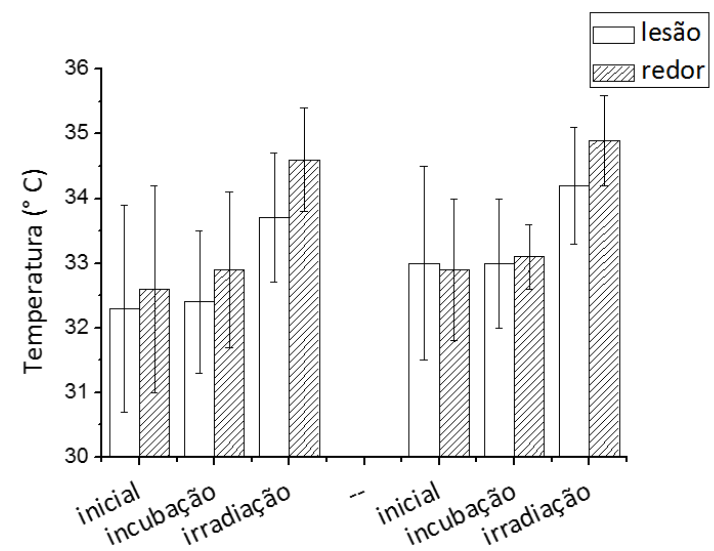

(A)

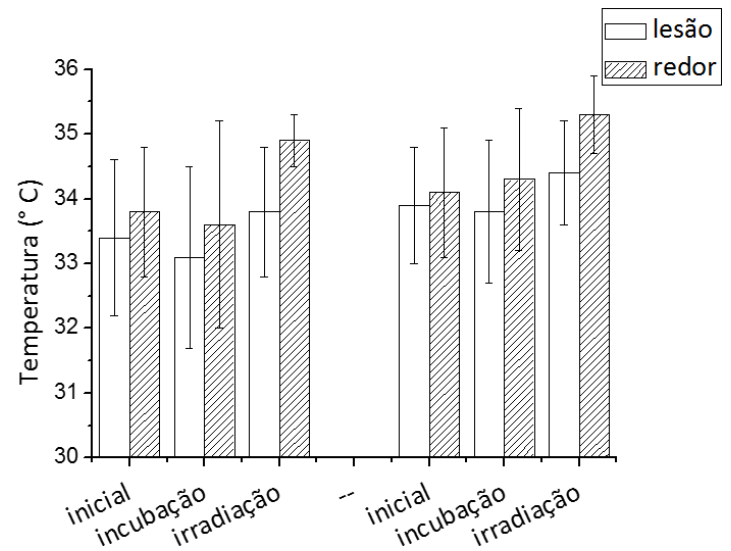

(B)

Figura 32 - Temperatura da região da lesão e na região adjacente durante a primeira sessão e a segunda sessão da Terapia Fotodinâmica (A) para as lesões com resposta completa ao tratamento e (B) para as lesões com resposta incompleta.

Fonte: Elaborada pela autora 
Como já visto nas imagens termográficas (Figuras 29 e 30), o gráfico da média das lesões mostra que a maior mudança de temperatura mais significativa ocorreu imediatamente após a iluminação, e a região sadia ao redor da lesão foi a que apresentou maior aquecimento. No início da segunda sessão, ambas as regiões possuíam temperatura maior que no início da sessão anterior, provavelmente devido ao processo inflamatório decorrente do procedimento anterior. Na segunda sessão, a diferença de temperatura entre a região da lesão e a do tecido saudável diminuiu após a iluminação, se comparada com a mesma diferença na primeira sessão. O motivo mais provável para isso é a diminuição de células tumorais na região resultante do primeiro procedimento.

Apenas quatro lesões acompanhados neste estudo apresentaram resposta incompleta ao tratamento na avaliação 30 dias após a TFD. Este número baixo é condizente com o resultado esperado na clínica (eliminação total da lesão em cerca de $90 \%$ dos casos tratados) e mostra uma boa eficiência do protocolo aplicado. Entretanto, este pequeno número de lesões não nos permite relacionar o comportamento térmico à sua resposta incompleta.

Os gráficos da Figura 32 sugerem que há menores diferenças de temperatura entre a região da lesão e o tecido ao redor no caso das lesões com resposta completa (Figura $32 \mathrm{~A}$ ) do que para lesões com resposta incompleta (Figura $32 \mathrm{~B}$ ), tanto na primeira quanto na segunda sessão, apesar das barras de erros. Isto deve-se ao fato de ocorrer maior eliminação de lesão no primeiro caso: com a morte das células tumorais presentes no tecido, as propriedades térmicas da região tendem a se tornar mais semelhantes às do tecido normal adjacente.

Também é importante salientar que em todas as lesões tratadas houve ação fotodinâmica, uma vez que mesmo nas 4 lesões com resposta incompleta ao tratamento ocorreu redução significativa do volume da lesão. Nestes casos, o tecido foi tratado, porém a dosimetria utilizada não foi suficiente para eliminar o volume tumoral por completo.

Os gráficos da Figura 32 também mostram que em nenhuma fase do procedimento houve aquecimento na região que fosse suficiente para causar qualquer tipo de dano térmico, já que este tipo de dano na pele acontece apenas quando o tecido atinge temperaturas superiores a $44^{\circ} \mathrm{C}$, o que não ocorreu. (70-72)

Também foram analisadas as variações de temperatura durante os procedimentos de TFD pelos gráficos do tipo box plot, apresentados na Figura 33. 


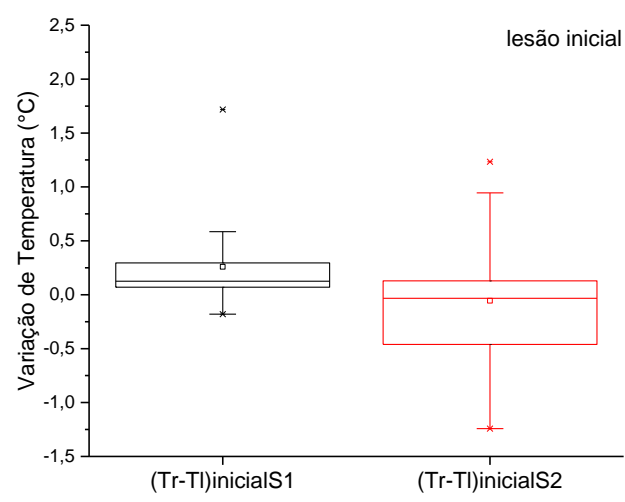

(A)

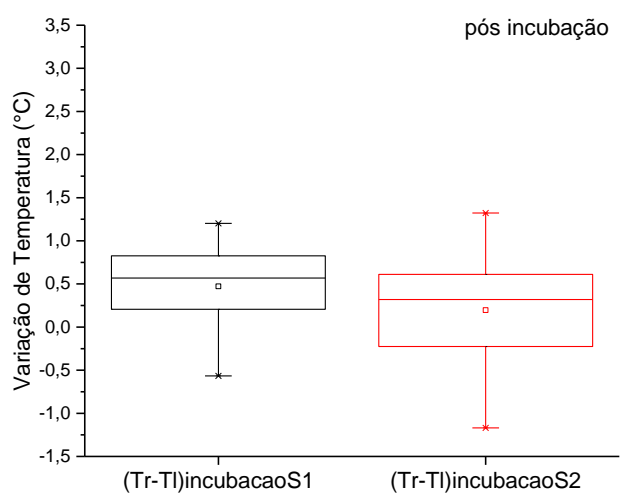

(B)

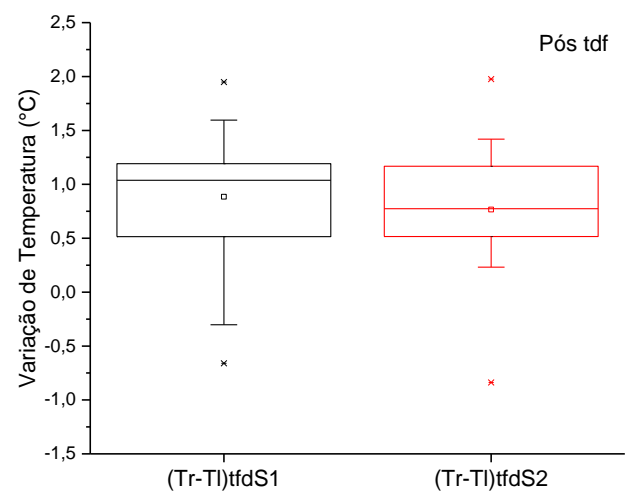

(C)

Figura 33 - (A) Diferença entre as temperaturas ao redor da lesão $(\mathrm{Tr})$ e dentro da lesão $(\mathrm{TI})$ no início dos procedimentos de primeira sessão (S1) e segunda sessão; (B) diferença entre as temperaturas ao redor da lesão (Tr) e dentro da lesão (TI) após a incubação do FS nos procedimentos de primeira sessão (S1) e segunda sessão e (C) diferença entre as temperaturas ao redor da lesão $(\mathrm{Tr})$ e dentro da lesão (TI) após os procedimentos de TFD de primeira sessão (S1) e segunda sessão.

Fonte: Elaborada pela autora

$\mathrm{Na}$ Figura 33 A é possível observar que no início da primeira sessão, a temperatura do tecido ao redor é maior que a temperatura na lesão em quase todos os casos. Já na segunda sessão, esse comportamento muda e metade das lesões passa ter temperatura maior na lesão. Isto ocorre devido ao tecido estar reagindo de diferentes maneiras ao primeiro procedimento: através do estabelecimento de necrose, de processo inflamatório e de cicatrização. Estas diferentes respostas 
também resultam na maior variabilidade nas diferenças de temperatura deste grupo, significando maior heterogeneidade de comportamento.

Na Figura 33 B também é possível observar, durante a incubação do FS, que a temperatura do tecido ao redor é maior que a temperatura na lesão em quase todos os casos da primeira sessão, e que esse comportamento muda em partes das lesões durante a segunda sessão. Também verificamos maior dispersão de valores durante a segunda sessão, o que pode ser explicado pelo fato do tecido possuir menor número de células tumorais remanescentes após o primeiro procedimento, e desta forma o FS acaba apresentando menor seletividade na região.

Na Figura $33 \mathrm{C}$ observa-se que, durante o procedimento de TFD, a temperatura adjacente aumenta mais que no tecido da lesão em praticamente todos os casos, durante as duas sessões do tratamento. Três fatores poderiam explicar isso: o aumento do aporte sanguíneo no tecido ao redor da lesão, devido ao aparecimento do processo inflamatório; a existência de diferença entre as propriedades dos tecidos normais e tumorais (como propriedades ópticas, condutividade térmica, densidade de vasos e taxa de perfusão sanguínea) que fazem com que a energia entrega seja convertida e dissipada em calor de formas diferentes; e o fato do tumor apresentar maior número de vasos na sua região periférica, podendo causar um efeito de resfriamento radiador (radiator-cooling) durante a irradiação. (63)

\section{Estimativa da quantidade de energia que foi utilizada no processo da TFD}

Os resultados mostrados nas Figuras 29, 30 e 31, é possível observar que a área da lesão e o tecido ao redor se comportam termicamente de maneira distintas durante o procedimento da TFD. Na Figura 34, TL é a temperatura no local da lesão, $T_{R}$ a temperatura na região ao redor da lesão que fica dentro da ponteira de iluminação, е Tт a da região do tecido não iluminada). De modo geral, ao longo do tratamento, verificou-se maior aquecimento na região ao redor $\left(T_{R}\right)$ se comparado com o tecido da lesão. 


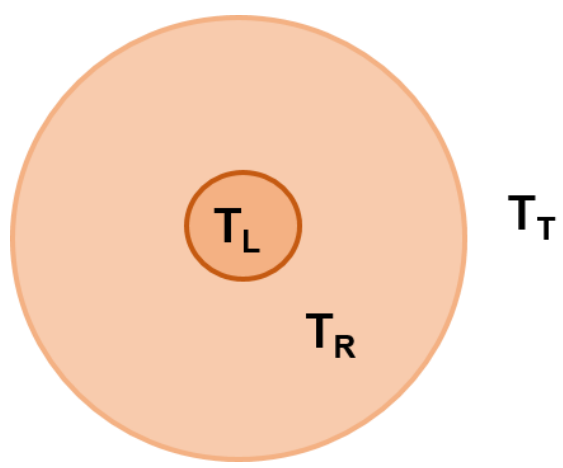

Figura 34 - Esquema das regiões que possuem comportamento térmico distintos. Fonte: Elaborada pela autora.

Em 3 voluntários, foi testado o comportamento térmico da pele durante a iluminação. Foi realizada a iluminação por 20 minutos em pele sadia, não lesionada, do antebraço direito, utilizando o mesmo protocolo do tratamento, porém sem administração prévia do precursor de PpIX. As imagens de termografia foram registradas a cada 2 minutos durante o período de iluminação e a cada 3 minutos após a iluminação, até que o tecido voltasse à sua temperatura inicial. Além disso, também foram utilizadas 3 das lesões investigadas para fazer o monitoramento da alteração térmica durante o procedimento de TFD e, após o término da iluminação, os valores de temperatura foram analisados dentro da lesão e na região iluminada ao seu redor, como mostra a Figura 35. 


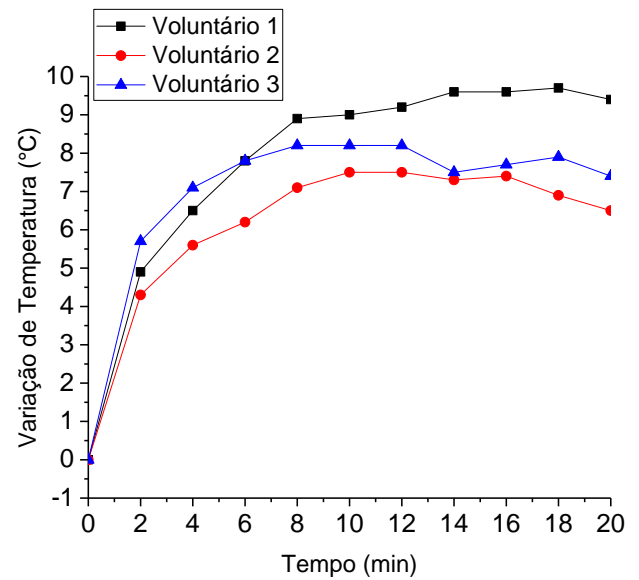

(A)

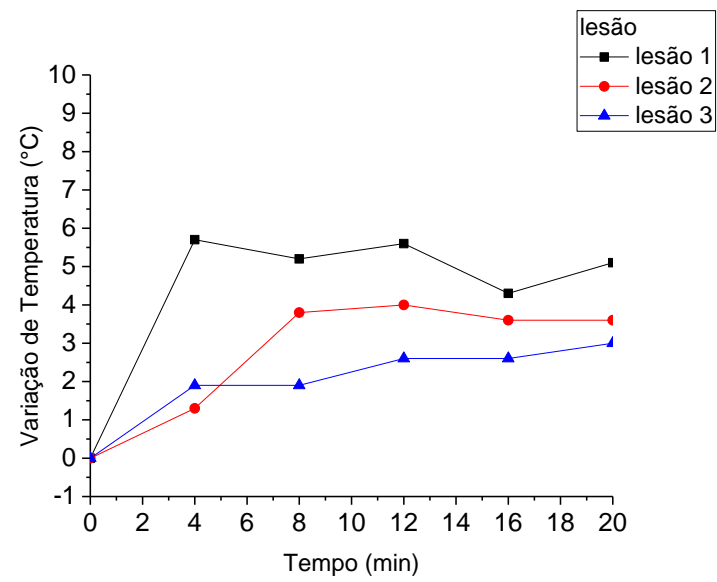

(C)

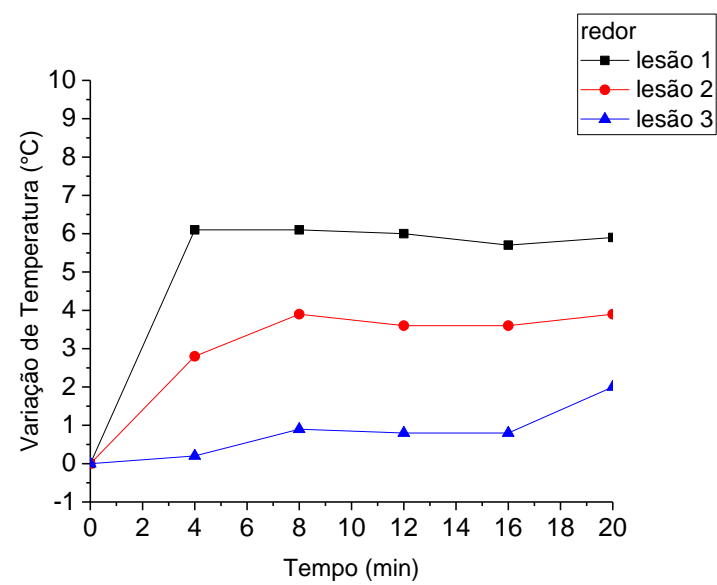

(E)

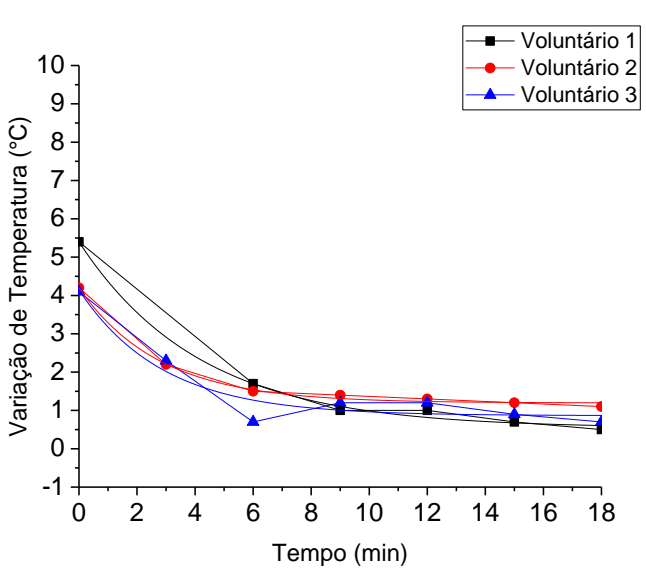

(B)

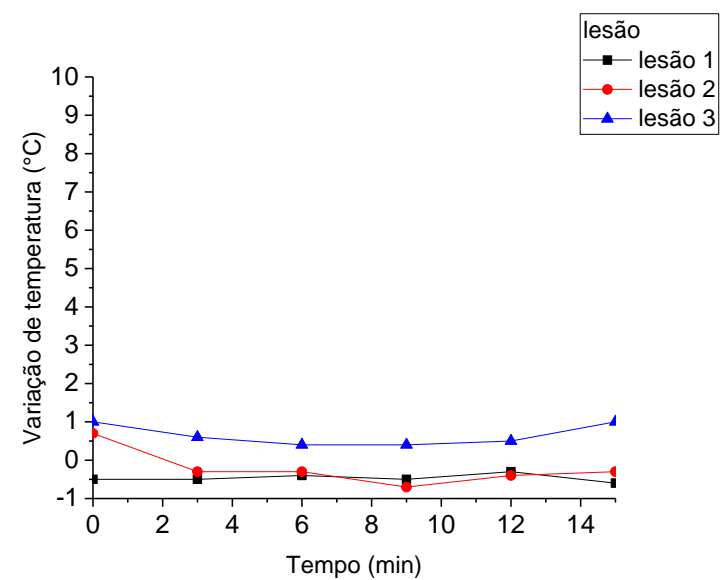

(D)

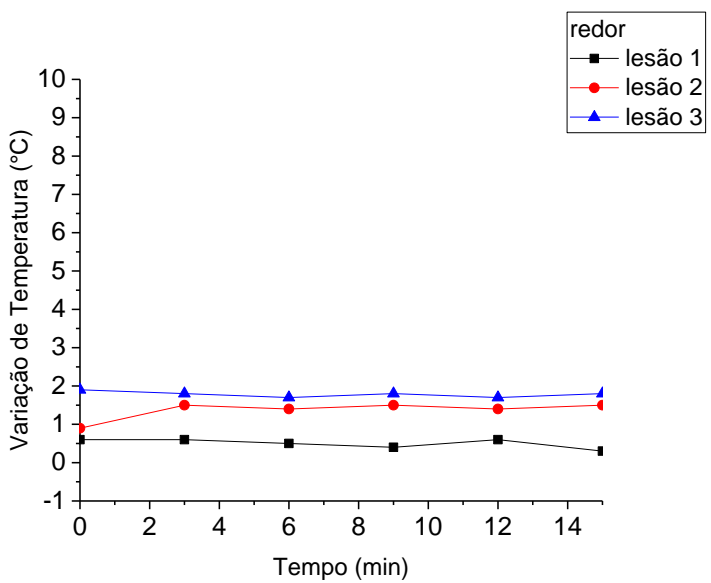

$(\mathrm{F})$

Figura 35 - (A) e (B) Variação de temperatura do período durante e após iluminação de pele sadia do antebraço de 3 voluntários, respectivamente; (C) e (D) variação de temperatura do período durante e após iluminação na área da lesão em procedimento de TFD; (E) e (F) variação de temperatura do período durante e após iluminação na área ao redor da lesão em procedimento de TFD.

Fonte: Elaborada pela autora. 
Podemos observar que, ao contrário dos comportamentos vistos em animais, em pele humana verificamos alteração nos padrões da variação de temperatura entre um tecido iluminado com e sem administração prévia do Metil-ALA. Porém, nestes casos, além dos próprios tecidos possuírem estruturas distintas, a presença ou não do tumor também modifica estas estruturas, como a distribuição e concentração de vasos na região, por exemplo, os quais dificultam uma comparação direta entre os dois modelos monitorados.

Verificamos que, nesta avaliação com iluminação de pele humana sem fotossensibilização prévia, a temperatura aumentou quase $10{ }^{\circ} \mathrm{C}$ durante $\mathrm{O}$ procedimento, conforme mostra a Figura $35 \mathrm{~A}$. Apesar desta considerável variação de temperatura, não houve dano térmico, visto que a temperatura inicial medida foi de cerca de $30^{\circ} \mathrm{C}$ e a máxima de $40^{\circ} \mathrm{C}$. Esta variação de temperatura pode ser justificada pelo fato de que quase toda a energia luminosa entregue é absorvida pelos cromóforos naturais da pele e acaba sendo convertida em calor. Neste caso, também se observa que o decaimento de temperatura é rápido: conforme visto na Figura 35 $B$, após cerca de 6 minutos a temperatura praticamente volta aos valores iniciais.

Em todos os tecidos iluminados (Figuras $35 \mathrm{~A}, \mathrm{C}$ e E) novamente observamos que o maior crescimento de temperatura acontece até os 5 minutos iniciais de iluminação e que, após esse período, esta temperatura se estabiliza. Porém, no tecido sadio sem TFD em que houve maior aumento de temperatura, Figura $35 \mathrm{~A}$, notamos que após cerca de 15 minutos de iluminação o tecido começa a resfriar novamente. Isso pode vir a ocorrer devido ao sistema vascular do tecido que, após a identificação da alteração da temperatura no local por meio de receptores na pele, o tecido aumenta o aporte sanguíneo na região e, consequentemente, a perfusão, o que evitará que ocorra dano térmico local. Este resfriamento induzido pela perfusão deverá ser estimulado no tecido até que a temperatura chegue a um limite mínimo, tolerável às funções metabólicas - o que comumente é próximo à temperatura inicial préiluminação. Outra observação é que as iluminações das lesões apresentaram maior temperatura no final da iluminação quando esta iluminação foi sendo interrompida para fazer as medidas. Este fato não foi encontrado na literatura e deve ser melhor investigado.

O resfriamento após o período de iluminação do tecido sem ação fotodinâmica (Figura 35 B) puderam ser ajustados a decaimentos exponenciais simples, do tipo 
$\Delta \mathrm{T}=\mathrm{A} \mathrm{e}^{\frac{-\mathrm{t}}{\tau}}+\mathrm{B}$, onde $\Delta T$ é a variação de temperatura sofrida na troca de calor, $A_{1}$ e yo parâmetros de ajuste, $t o$ tempo de decaimento, e $t_{1}$ a constante de decaimento. Já o aumento de temperatura durante a iluminação, como se vê na Figura $35 \mathrm{~A}$, depende de dois fatores: 0 aumento linear da temperatura com a entrega constante de energia durante o procedimento (que pode ser representado por $Q=m c \Delta T$, onde $Q$ é a quantidade de calor, $m$ a massa do corpo, $c o$ calor específico) e da dissipação de temperatura da pele provocada pela perfusão térmica do próprio tecido. Assim, foi feito o ajuste das curvas de aquecimento considerando essas duas contribuições, obtendo-se o produto de um aumento linear com um decaimento exponencial: $\Delta \mathrm{T}=$ $(A t+B) e^{\frac{-t}{\tau}}$ (onde $A, B$ e $C$ são parâmetros de ajuste). Os coeficientes dos ajustes podem ser encontrados na Tabela 4.

Tabela 4 - Valores dos ajustes das curvas dos três voluntários para o aumento e decaimento de temperatura durante e após o período de iluminação.

Ajuste das curvas da Figura $35 \mathrm{~A}$ : aumento de temperatura durante iluminação.

$$
\Delta \mathrm{T}=(\mathrm{At}+\mathrm{B}) \mathrm{e}^{\frac{-\mathrm{t}}{\tau}}
$$

\begin{tabular}{cccc}
\hline & Voluntário 1 & Voluntário 2 & Voluntário 3 \\
\hline $\mathrm{A}$ & $1,9 \pm 0,2$ & $1,7 \pm 0,1$ & $2,1 \pm 0,3$ \\
$\mathrm{~B}$ & $0,8 \pm 0,5$ & $0,6 \pm 0,4$ & $1,0 \pm 0,7$ \\
$\mathrm{C}$ & $13 \pm 1$ & $11 \pm 1$ & $10 \pm 1$ \\
\hline
\end{tabular}

Ajuste das curvas da Figura 35 B: decaimento de temperatura após iluminação.

$$
\Delta \mathrm{T}=A \mathrm{e}^{\frac{-\mathrm{t}}{\tau}}+\mathrm{B}
$$

\begin{tabular}{rrrc}
\hline & Voluntário 1 & Voluntário 2 & Voluntário 3 \\
\hline $\mathrm{A}_{1}$ & $4,9 \pm 0,2$ & $3,0 \pm 0,1$ & $3,3 \pm 0,4$ \\
$\mathrm{t}_{1}$ & $4,2 \pm 0,5$ & $2,8 \pm 0,2$ & $3 \pm 1$ \\
$\mathrm{y}_{0}$ & $0,5 \pm 0,1$ & $1,2 \pm 0,1$ & $0,9 \pm 0,2$ \\
\hline
\end{tabular}

Fonte: Elaborada pela autora.

Também graficamos as curvas de temperatura nas periferias das superfícies iluminadas (Figura 36 A) onde verificamos o seu decrescimento ao passar da superfície onde ocorreu para onde não ocorreu iluminação direta. Na Figura 36 B, apresenta-se um exemplo de curva mostrando esse gradiente de temperatura nessa superfície. 


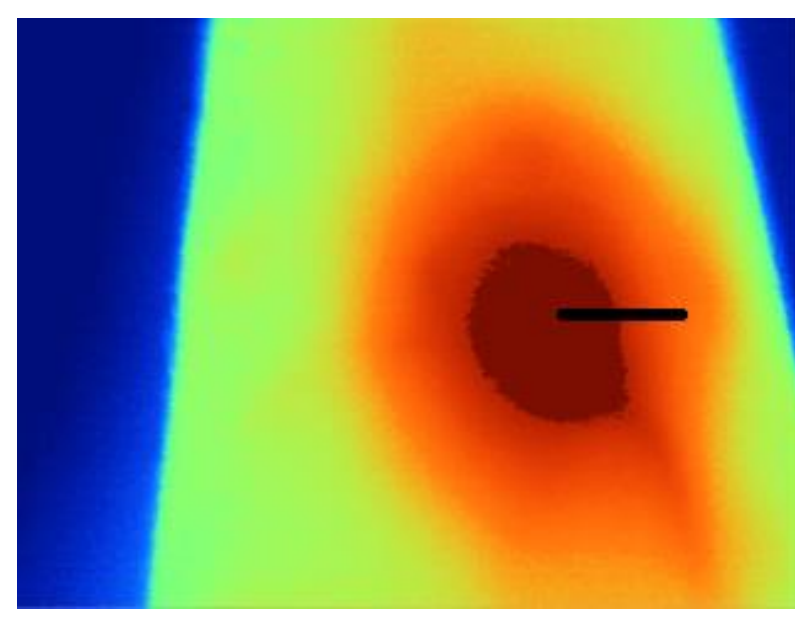

(A)

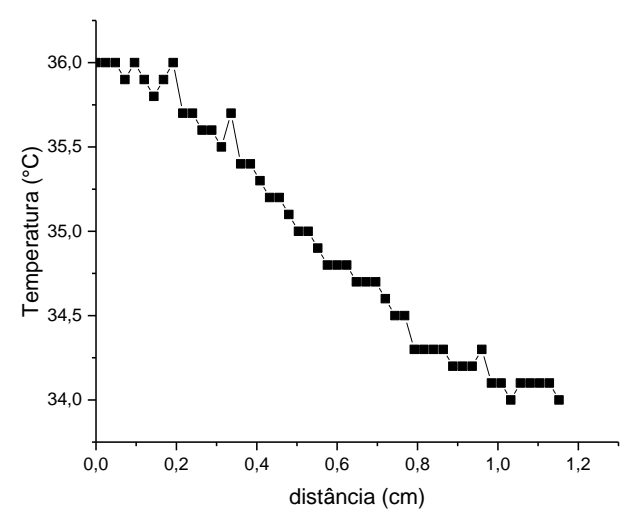

(B)

Figura 36 - (A) Local da periferia da área iluminada em que foi realizada a curva de variação de temperatura e (B) exemplo de curva gerada.

Fonte: Elaborada pela autora.

Para cada voluntário, foram graficadas duas curvas de locais distintos da borda iluminada, traçando duas retas perpendiculares. Os ajustes foram realizados utilizando uma exponencial do tipo: $\Delta \mathrm{T}=\mathrm{A} \mathrm{e}^{\frac{-\mathrm{x}}{\tau}}+\mathrm{B}$ e os valores encontrados pelos ajustes encontram-se na Tabela 5.

Tabela 5 - Valores de ajustes para as curvas de variação de temperatura nas periferias das áreas iluminadas

Ajuste das curvas da Figura 36 B: decaimento de temperatura após iluminação.

$$
\Delta \mathrm{T}=A \mathrm{e}^{\frac{-\mathrm{x}}{\tau}}+\mathrm{B}
$$

\begin{tabular}{|c|c|c|c|}
\hline & Voluntário 1 & Voluntário 2 & Voluntário 3 \\
\hline$A_{1}$ & $6 \pm 1$ e $9 \pm 3$ & $10 \pm 3$ e $8 \pm 2$ & $3,4 \pm 0,3$ e $4,4 \pm 0,8$ \\
\hline$t_{1}$ & $2,3 \pm 0,8$ e $3 \pm 1$ & $2,2 \pm 0,6$ e $1,5 \pm 0,4$ & $1,1 \pm 0,2$ e $0,8 \pm 0,2$ \\
\hline \multirow[t]{2}{*}{$\mathrm{y}_{0}$} & $30 \pm 2$ e $43 \pm 3$ & $-67 \pm 3$ e $45 \pm 2$ & $38,6 \pm 0,5 \mathrm{e}$ \\
\hline & & & $32,1 \pm 0,8$ \\
\hline
\end{tabular}

Fonte: Elaborada pela autora.

Pelas imagens de fluorescência da Figura 31, a formação de PpIX fica praticamente restrita à área da lesão durante a primeira sessão, quando a fotossensibilização se mostra mais seletiva. Podemos considerar, de modo 
aproximado, que a dose de luz depositada sobre o tecido durante o procedimento de TFD é convertida de acordo com a expressão (4).

$$
E=E^{\prime}+Q_{l}+Q_{r}+E_{T F D}+\Delta Q_{d i s}+\Delta Q_{p e r}
$$

A Tabela 6 apresenta os valores e expressões de cada componente.

Tabela 6 - Siglas e valores usados para cada termo de energia convertida durante a iluminação do procedimento da TFD.

\begin{tabular}{|c|c|c|}
\hline$E$ & 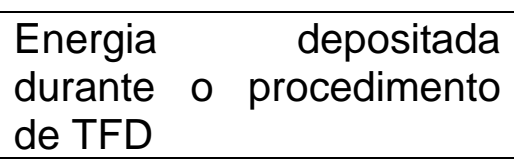 & $471 \mathrm{~J}$ \\
\hline$E^{\prime}$ & $\begin{array}{lll}\text { Energia refletida } & \text { na } \\
\text { superfície do tecido } & \\
\end{array}$ & $23,55 \mathrm{~J}=5 \% E(73)$ \\
\hline \multirow[t]{2}{*}{$Q_{l}$} & $\begin{array}{ll}\text { Energia } & \text { convertida } \\
\text { termicamente } & \text { na região }\end{array}$ & $\rho A_{l} e c \Delta T_{l}$ \\
\hline & & $\begin{array}{l}\text { Onde } \rho \text { é a densidade do } \\
\text { tecido, } A_{l} \text { é a área da lesão, } e \text { a } \\
\text { espessura do tecido e } \Delta T_{l} \text { a } \\
\text { variação de temperatura na } \\
\text { lesão. O valor de } Q_{l} \text { utilizado na } \\
\text { expressão foi o valor médio de } \\
\text { todas as lesões. }\end{array}$ \\
\hline \multirow[t]{2}{*}{$Q_{r}$} & \begin{tabular}{ll} 
Energia & \multicolumn{2}{c}{ convertida } \\
termicamente na região
\end{tabular} & $\rho\left(A_{p}-A_{l}\right) e c \Delta T_{l}$ \\
\hline & & $\begin{array}{l}\text { Onde } \rho \text { é a densidade do } \\
\text { tecido, } A_{p} \text { é a área da ponteira } \\
\text { de iluminação (cujo raio é de } 1 \\
\mathrm{~cm} \text { ), } A_{l} \text { é a área da lesão, e a } \\
\text { espessura do tecido e } \Delta T_{r} \text { a } \\
\text { variação de temperatura ao } \\
\text { redor da lesão. O valor de } Q_{r} \\
\text { utilizado na expressão foi o } \\
\text { valor médio de todas as } \\
\text { regiões. }\end{array}$ \\
\hline$E_{T F D}$ & $\begin{array}{l}\text { Energia convertida em } \\
\text { ação fotodinâmica }\end{array}$ & $\begin{array}{l}\text { Resulta da diferença entre a } \\
\text { energia total depositada e as } \\
\text { demais } \\
\text { apresentadas. }\end{array}$ \\
\hline
\end{tabular}

(continua) 
(continuação)

\begin{tabular}{|c|c|c|c|}
\hline \multirow[t]{2}{*}{$\Delta Q_{\text {dis }}$} & \multirow{2}{*}{\multicolumn{2}{|c|}{$\begin{array}{l}\text { Energia dissipada pelo } \\
\text { tecido na periferia da } \\
\text { região aquecida }\end{array}$}} & $\Delta t \pi R_{p} e \frac{\Delta T}{\tau} k$ \\
\hline & & & $\begin{array}{l}\text { Onde } \Delta t \text { é o tempo de } \\
\text { iluminação, } \Delta T \text { e } t_{1} \text { são a } \\
\text { variação de temperatura e o } \\
\text { decaimento característico na } \\
\text { periferia da região iluminada, } \\
\text { pelo ajuste da curva da Figura } \\
36 \text { (o valor utilizado foi a média } \\
\text { dos valores encontrados para } \\
\text { cada voluntário) e } k \text { é a } \\
\text { condutividade térmica. }\end{array}$ \\
\hline \multirow[t]{3}{*}{$\Delta Q_{p e r}$} & $\begin{array}{l}\text { Energia perdida } \\
\text { perfusão sanguínea }\end{array}$ & pela & $\iint \rho_{s} c \omega \rho_{t}\left(T_{s}-T\right) d V(74)$ \\
\hline & & & $\begin{array}{l}\text { Onde } \rho_{s} \text { é a densidade do } \\
\text { sangue }\left(1060 \mathrm{~kg} / \mathrm{m}^{3}\right)(75), c \text { é o } \\
\text { calor específico, } \omega \text { é a taxa de } \\
\text { perfusão do sangue (utilizamos } \\
\text { o valor médio entre homem e } \\
\text { mulher } 9,2 \mathrm{ml} / 60 \mathrm{~s} .01 \mathrm{~kg})(76), \rho_{t} \\
\text { é a densidade do tecido, } T_{s} \text { é a } \\
\left.\text { temperatura do sangue ( } 37^{\circ} \mathrm{C}\right) \\
\text { e } T=A_{1} e^{\frac{-x}{t_{1}}}+y_{0} \text { (onde os } \\
\text { coeficientes utilizados foram as } \\
\text { médias dos obtidos pelos } \\
\text { ajustes das curvas da Figura } 35 \\
\text { B, decaimento do tecido } \\
\text { saudável após iluminação sem } \\
\text { ação fotodinâmica). } \\
\text { Como podemos considerar que } \\
\text { toda a área da ponteira é } \\
\text { iluminada de forma uniforme, } \\
\text { não há variação de temperatura } \\
\text { no volume considerado, logo: }\end{array}$ \\
\hline & & & $\int A_{p} e \rho_{s} c \omega \rho_{t}\left(T_{s}-T\right) d t$ \\
\hline
\end{tabular}

Fonte: Elaborada pela autora.

Os valores de $e, \rho$ e $k$ foram utilizados baseados na Tabela 7. Considerando que a espessura da epiderme é praticamente desprezível e que a condutividade térmica na derme é muito maior que a camada adjacente, no subcutâneo, foi possível considerar, em nossas aproximações, que o calor foi produzido basicamente na camada da derme. 
Tabela 7 - Propriedades térmicas da pele.

\begin{tabular}{ccccc}
\hline & $\begin{array}{c}\text { Espessura } \\
(\mathrm{m})\end{array}$ & $\begin{array}{c}\text { Calor } \\
\text { específico } \\
{\left[\mathrm{J} / \mathrm{kg} .{ }^{\circ} \mathrm{C}\right]}\end{array}$ & $\begin{array}{c}\text { Condutividade } \\
\text { térmica } \\
{\left[\mathrm{W} / \mathrm{m}{ }^{\circ} \mathrm{C}\right]}\end{array}$ & $\begin{array}{c}\text { Densidade } \\
{\left[\mathrm{kg} / \mathrm{m}^{3}\right]}\end{array}$ \\
\hline Epiderme & $80 \times 10^{-6}$ & 3590 & 0,24 & 1200 \\
Derme & 0,002 & 3300 & 0,45 & 1200 \\
Subcutâneo & 0,01 & 2500 & 0,19 & 1000 \\
\hline \multicolumn{5}{c}{ Fonte: Adaptada de JIANG. (69) }
\end{tabular}

Com a realização dos cálculos obteve-se cada componente de energia convertida durante o procedimento de iluminação da TFD, Tabela 8.

Tabela 8 - Valores das componentes de energias convertidas durante o procedimento de TFD

\begin{tabular}{|c|c|c|c|c|c|c|}
\hline$E$ & $E^{\prime}$ & $Q_{l}$ & $Q_{r}$ & $\Delta Q_{d i s}$ & $\Delta Q_{p e r}$ & $E_{T F D}$ \\
\hline $471 \mathrm{~J}$ & $24 \mathrm{~J}$ & 0 & 2,3 J & $17 \mathrm{~J}$ & $174 \mathrm{~J}$ & $253 \mathrm{~J}$ \\
\hline $100,0 \%$ & $5,0 \%$ & $0 \%$ & $0,5 \%$ & $3,6 \%$ & $37,2 \%$ & $53,8 \%$ \\
\hline
\end{tabular}

Fonte: Elaborada pela autora.

Com isso, estimou-se que, apesar das aproximações realizadas, a maior parte da energia depositada é convertida em ação fotodinâmica (53,8\%), seguida da parcela que foi dissipada pela perfusão do sangue $(37,2 \%)$. Entretanto, trata-se de um modelo simplificado, e alguns outros fenômenos que podem ocorrer não puderam ser considerados na estimativa. Tais fenômenos como fluorescência e fosforescência que também consomem energia para ocorrer.

Em TFD costuma-se questionar a componente térmica que porventura resulte do depósito de altas doses de luz no tecido. Esse resultado mostra que a maior parte da energia depositada é consumida na ativação do FS e, portanto, no efeito fotodinâmico. Se for considerada a energia luminosa absorvida pelo FS, a energia térmica dissipada pela perfusão sanguínea e a energia refletida pelo tecido, menos de $1 \%$ da energia total depositada se converte em aquecimento local do tecido. Isso mostra que a TFD não provoca danos de origem térmica na dose utilizada, o que 
sugere que a técnica não apresenta componente térmica relevante no que diz respeito a dano tecidual. 


\section{6} CONCLUSÕES

No estudo em animais, os tumores apresentaram uma menor temperatura em comparação com os tecidos adjacentes, compatíveis com as características morfológicas do modelo empregado e tumores a partir de $4 \mathrm{~mm}$ de diâmetro foram detectados.

A termografia mostrou ser uma ferramenta eficaz auxiliar no diagnóstico clínico, permitindo uma triagem rápida de lesões suspeitas e fornecendo uma maneira rápida de encaminhar o paciente destas lesões ao especialista adequado. No estudo clínico, os resultados foram promissores para o par CECxQA, que possui grande relevância epidemiológica. O par melanomaxQSP apresentou os menores índices, no entanto, a detecção de melanoma metastático pode ser de relevância diagnóstica.

O monitoramento da TFD em CBC demonstrou alterações teciduais que puderam ser detectadas pela termografia e o modelo matemático de energia proposto, demonstra que cerca de $53,8 \%$ da energia luminosa entregue é convertida em reação fotodinâmica e que o efeito térmico decorrente da irradiação no tecido fotossensilizado é praticamente nulo. 


\section{REFERÊNCIAS}

1 BARBOSA, M.B. A. A situação do câncer no Brasil. In: BARBOSA, M. B. A. (Ed.). Ações de enfermagem para o controle do câncer: uma proposta de integração ensino-serviço. 3. ed. Rio de Janeiro: T. Facina, 2008. cap. 1, p. 5-32.

2 RING, F.J.; JONES, B. F. Historical development of thermometry and thermal imaging in medicine. In: DIAKIDES, M.; BRONZINO, J. B.; PETERSON, D. R. (Ed.). Medical infrared imaging: principles and practices. Boca Raton: Taylor \& Francis Group, 2013. cap. 2, p. 2.1-2.6.

3 KENNEDY, D. A.; LEE, T.; SEELY, D. A comparative review of thermography as a breast cancer screening technique. Integrative Cancer Therapies. v. 9, n. 1, p. 9-16, 2009.

4 DETECTORES de infravermelho - princípios e caracterização. São José dos Campos: INPE. Disponível em: <http://www.las.inpe.br/ cesar/Infrared/detectores.htm>. Acesso em: 29 set. 2016.

5 GORE, J. P.; XU, L. X. Thermal Imaging for biological and medical diagnostics. In: VO-DINH, T. (Ed.). Biomedical photonics. Boca Raton: CRC PRESS, 2003. cap. 17. p. $446-457$.

6 BERZ, R.; SAUER, H. The medical use of infrared-thermography history and recent applications. 2007.Disponível em: <http://www.ndt.net/article/dgzfp-irt2007/Inhalt/v04.pdf>. Acesso em: 23 jan. 2016.

7 NIKLAUS, F. et al. Performance model for uncooled infrared bolometer arrays and performance predictions of bolometers operating at atmospheric pressure. Infrared Physics and Technology. v. 51, n. 3, p. 168-177, 2008.

8 JONES, B. F. A reappraisal of the use of infrared thermal image analysis in medicine. IEEE Transactions on Medical Imaging, v.17, n. 6, p. 1019-1027, 1998.

9 KERR, J.; ZEALAND, N. Review of the effectiveness of infrared thermal imaging (thermography) for population screening and diagnostic testing of breast cancer. 2004.2 Disponível em: $<$ https://www.nsu.govt.nz/system/files/resources/review-of-the-effectiveness-ofthermography.pdf>. Acesso em 23 jan. 2015.

10 BRIOSCHI, M. L.; MACEDO, J. F.; MACEDO, R. D. A. C. Termometria cutânea: novos conceitos. Journal Vascular Brasileiro. v. 2, n. 2, p. 151-160, 2003.

$11 \mathrm{BRIOSCHI}$, M. L. et al. O uso da termografia infravermelha na avaliação do retorno ao trabalho em programa rehabilitation program ( PRA ). Acta Fisiátrica. v. 16, n. 2, p. 87-92, 2009.

12 BRIOSCHI, M.L. et al. Utilização da imagem infravermelha em reumatologia Infrared imaging use in rheumatology. Revista Brasileira de Reumatologia. v. 47, n.1, p. 42-51, 2007. 
13 SHADA, A. L. et al. Infrared thermography of cutaneous melanoma metastases. Journal of Surgical Research. v. 182, n. 1, p. 9-14, 2013.

14 HELMY, A.; HOLDMANN, M.; RIZKALLA, M. Application of thermography for noninvasive diagnosis of thyroid gland disease. IEEE Transactions on Biomedical Engineering. v. 55, n. 3, p. 1168-1175.

$15 \mathrm{CHI}-\mathrm{ANH}, \mathrm{N}$. et al. Characterization of uncooled bolometer with vanadium tungsten oxide infrared active layer. Sensors and Actuators. v. 123-124, n. A, p. 87-91, 2005.

16 NORTON, P. R. et al. Infrared detectors and detector arrays. In: DIAKIDES, M.; BRONZINO, J. B.; PETERSON, D. R. (Ed.). Medical infrared imaging: principles and practices. Boca Raton: Taylor \& Francis Group, 2013. cap. 3. p. 3.1-3.27.

17 ARKIN, H; XU, L. X.; HOLMES, K. R. Recent developments in modeling heat transfer in blood perfused tissues. IEEE Transactions on Biomedical Engineering, v. 41, n. 2, p. 97-107, 1994.

18 TEPPER, M.; GANNOT, I. Monitoring tumor state from thermal images in animal and human models. Medical Physics, v. 42, n. 3, p. 1297-1306, 2015.

19 THERMOPHYSICAL characteristics of various body tissues, organs, and other materials. Cambridge: Harvar Medical School. Disponível em: <http://kirschner.med.harvard.edu/files/bionumbers/Thermophysical\%20characteristic s\%20of\%20body\%20tissues\%20and\%20organs\%20and\%20other\%20materials.pdf> . Acesso em: 30 nov. 2016.

20 JONES, B. F.; PLASSMANN, P. Digital infrared thermal imaging of human skin. IEEE Engineering in Medicine and Biology, v. 21, n. 6, p. 41-48, 2002.

21 LAHIRI, B. B. et al. Medical applications of infrared thermography: a review. Infrared Physics and Technology, v. 55, n. 4, p. 221-235, 2012.

22 TEPPER, M. et al. Thermographic investigation of tumor size, and its correlation to tumor relative temperature, in mice with transplantable solid breast carcinoma. Journal of Biomedical Optics, v. 18, n. 11, p. 111410-1-111410-10, 2013.

23 CHAKRABORTY, M. et al. A new paradigm of oral cancer detection using digital infrared thermal imaging. SPIE Medical Imaging, p. 97853I-97853I-7, 2016. doi: 10.1117/12.2216785.

24 GONZÁLEZ, J. R. et al. An approach for thyroid nodule analysis using thermographic images. Application of Infrared to Biomedical Sciences, p. 451-475, 2017. doi: 10.1007/978-981-10-3147-2_26.

25 CASTILHO, I. G.; SOUSA, M. A. A.; LEITE, R. M. S. Fotoexposição e fatores de risco para câncer da pele: uma avaliação de hábitos e conhecimentos entre estudantes universitários. Anais Brasileiros de Dermatologia, v. 85, n. 2, p. 173178, 2010.

26 ROCHA, F. P. et al. Especificidade e sensibilidade de rastreamento para lesões cutâneas pré-malignas e malignas. Revista de Saúde Pública, v. 36, n. 1, p. 101106, 2002. 
27 RUBIN, A. I.; CHEN, E. H.; RATNER, D. Basal-cell carcinoma. New England Journal of Medicine, v. 353, n. 21, p. 2262-2269, 2005.

28 DORNELAS, M. T. et al. Expressão de marcadores de proliferação celular e apoptose no carcinoma espinocelular de pele e ceratose actínica. Anais Brasileiros de Dermatologia, v. 84, n. 5, p. 469-475, 2009.

29 DE GIORGI, V. et al. False "melanocytic" parameters shown by pigmented seborrheic keratoses: a finding which is not uncommon in dermoscopy. Dermatologic Surgery, v. 28, n. 8, p. 776-779, 2002.

30 REZZE, G. G.; DE SÁ, B. C. S.; NEVES, R. I. Dermoscopy: the pattern analysis. Anais Brasileiros de Dermatologia, v.81, n. 3, p. 261-268, 2006.

31 HADDAD, R. et al. In vitro and in vivo effects of photodynamic therapy on murine malignant melanoma. Annals of Surgical Oncology, v. 5, n. 3, p. 241-247, 1998.

32 ARORA, N. et al. Effectiveness of a noninvasive digital infrared thermal imaging system in the detection of breast cancer. American Journal of Surgery, v. 196, n. 4, p. 523-526,2008.

33 BUZUG, T. M. et al. Functional infrared imaging for skin-cancer screening. Engineering in Medicine and Biology Society, p. 2766-2769, 2006. doi: 10.1109/IEMBS.2006.259895.

34 HANNUKSELA-SVAHN, A.; PUKKALA, E.; KARVONEN, J. Basal cell skin carcinoma and other nonmelanoma skin cancers in finland from 1956 through 1995. Archives of Dermatology. v. 135, n. 7, p. 781-786, 2015.

35 MARKS R. Squamous cell carcinoma. Lancet. v. 347, n. 9003, p. 735-738, 1996.

36 WINSEY, S. L. et al. A variant within the DNA repair gene XRCC3 is associated with the development of melanoma skin cancer. Cancer Research. v. 60, n. 20, p. 5612-5616, 2000.

$37 \mathrm{KOH}, \mathrm{H}$. K. et al. Evaluation of the American Academy of Dermatology's national skin cancer early detection and screening program. Journal of the American Academy of Dermatology. v. 34, n. 6, p. 971-978, 1996.

$38 \mathrm{MOY}, \mathrm{R}$. L. Clinical presentation of actinic keratoses and squamous cell carcinoma. Journal of the American Academy of Dermatology. v. 42, n. 1, p. 8-10, 2000.

39 COCKERELL, C. J. Histopathology of incipient intraepidermal squamous cell carcinoma ("actinic keratosis"). Journal of the American Academy of Dermatology. v. 42 , n. 1, p. 11-17, 2000.

40 GODOY, S. E. et al. Dynamic infrared imaging for skin cancer screening. Infrared $\begin{array}{llllll}\text { Physics and Technology. v. } & 015 .\end{array}$ doi.org/10.1016/j.infrared.2014.09.017.

41 CHENG, T. Y.; HERMAN, C. Analysis of skin cooling for quantitative dynamic infrared imaging of near-surface lesions. International Journal of Thermal Sciences, v. 86, p. 175-188, 2014. doi.org/10.1016/j.jthermalsci.2014.06.033. 
42 WILSON, B. C.; PATTERSON, M. S. The physics, biophysics and technology of photodynamic therapy. Physics in Medicine and Biology. v. 53, n. 9, p. 61-109, 2008.

43 ROBERTSON, C. A.; EVANS, D. H.; ABRAHAMSE, H. Photodynamic therapy (PDT): a short review on cellular mechanisms and cancer research applications for PDT. Journal of Photochemistry and Photobiology. v. 96, n. 1, p. 1-8, 2009.

44 BAGNATO, V. S. As novas técnicas ópticas para as áreas da saúde. São Carlos: Editora Livraria da Física, 2008.

45 NIEMZ, M. H. Light and matter. In: NIEMZ, M. H. (Ed.). Biological and medical physics, biomedical engineering: laser-tissue interactions. 3rd ed. Berlin: Springer, 2007. cap. 2. p. 9-44.

46 PLAETZER, K. et al. Photophysics and photochemistry of photodynamic therapy: fundamental aspects. Lasers in Medical Science, v. 24, n. 2, p. 259-268, 2009.

47 TOREZAN, L.; NIWA, A. B. M.; FESTA NETO, C. Terapia fotodinâmica em dermatologia: princípios básicos e aplicações. Anais Brasileiros de Dermatologia, v. 84 , n. 5, p. 445-459, 2009.

48 MACCORMACK, M. A. Photodynamic therapy in dermatology: an update on applications and outcomes. Seminars in Cutaneous Medicine and Surgery, v. 27, n 1, p. 52-62, 2008.

49 ISHIMARU, A. Diffusion of light in turbid material. Applied Optics, v. 28, n. 12, p. 2210-2215, 1989.

50 DE VELD, D. C. G. et al. Autofluorescence and diffuse reflectance spectroscopy for oral oncology. Lasers in Surgery and Medicine. v.36, n. 5, p. 356-354, 2005.

51 VALENTINE, R. M. et al. A quantitative comparison of 5-Aminolaevulinic acid- and methyl aminolevulinate-induced fluorescence, photobleaching and pain during photodynamic therapy. Photochemistry and Photobiology. v. 87, n. 1, p. 242-249, 2011.

52 FLUKE Ti400 Infrared Camera. Everett: Fluke®. Disposínel em: <http://enus.fluke.com/products/infrared-cameras/fluke-ti400-infrared-camera.html>. Acesso em: 29 set. 2016.

53 FERNANDES, P. D. et al. Characterization of the inflammatory response during Ehrlich ascitic tumor development. Journal of Pharmacological and Toxicological Methods. v. 71, p. 83-89, 2015. doi: 10.1016/j.vascn.2014.09.001.

54 RAMIREZ, D. P. et al. Experience and BCC subtypes as determinants of MAL-PDT response: preliminary results of a national Brazilian project. Photodiagnosis and Photodynamic Therapy. v. 11, n, 1, p. 22-26, 2014.

55 GONZALEZ, R. C.; WOODS, R. E. Digital image processing. Upper Saddle River: Pearson, 2007.

56 ACHARYA, T.; RAY, A. K. Image processing: principles and applications. Hoboken: John Wiley \& Sons, 2005. 
57 COSTA, L. F.; CESAR JUNIOR. R. M. Shape analysis and classification: theory and practice. Boca Raton: CRC Press, 2000.

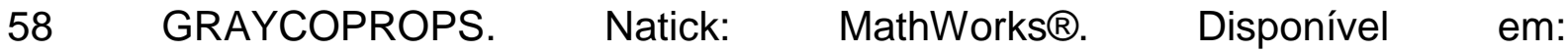
<http://www.mathworks.com/help/images/ref/graycoprops.html>. Acesso em: 29 set. 2016.

59 EL-NAQA, I. et al. A support vector machine approach for Detection of Microcalcifications. IEEE Transactions on Medical Imaging. v. 21, n. 12, p. 15521563, 2002.

60 CHAPLOT, S.; PATNAIK, L. M.; JAGANNATHAN, N. R. Classification of magnetic resonance brain images using wavelets as input to support vector machine and neural network. Biomedical Signal Processing and Control. v. 1, n. 1, p. 86-92, 2006.

61 RICCI. E.; PERFETTI. R. Retinal blood vessel segmentation using line operators and support vector classification. IEEE Transactions on Medical Imaging, v. 26, n. 10, p. 1357-1365, 2007.

$62 \mathrm{MACHADO}, \mathrm{H}$. Atividade dos favonóides rutina e naringina sobre o tumor ascítico de Ehrlich "in vivo." 2006. 104 p. Dissertação (Mestrado em Bioquímica Agrícola) - Universidade Federal de Viçosa, Viçosa, 2006.

63 ORENSTEIN, A. et al. Malik Z. temperature monitoring during photodynamic therapy of skin tumors with topical 5-aminolevulinic acid application. Cancer Letters, v. 93, n. 2, p. 227-232, 1995.

64 LALLAS, A. et al. The clinical and dermoscopic features of invasive cutaneous squamous cell carcinoma depend on the histopathological grade of differentiation. British Journal of Dermatology, v. 172, n. 5, p. 1308-1315, 2015.

65 SHADA, A. L. et al. Infrared thermography of cutaneous melanoma metastases. Journal of Surgical Research, v. 182, n. 1, p. e9-e14, 2013.

66 STROBEL, K. et al. High-risk melanoma: accuracy of FDG PET/CT with added CT morphologic information for detection of metastases 1 . Radiology, v. 244, n. 2, p. 566574, 2007.

67 REINHARDT, M. J. et al. Diagnostic performance of whole body dual modality $18 \mathrm{~F}-$ FDG PET/CT imaging for $\mathrm{N}$ - and $\mathrm{M}$-staging of malignant melanoma: experience with 250 consecutive patients. Journal of Clinical Oncology, v. 24, n. 7, p. 1178-1187, 2006.

68 PET/CT oncológico. Porto Alegre: InsCer - Instituto do Cérebro. Disponível em: <http://inscer.pucrs.br/centro-imagem/petct-oncologico/>. Acesso em: 31 maio 2017.

69 JIANG, S. C. et al. Effects of thermal properties and geometrical dimensions on skin burn injuries. Burns, v. 18, n. 8, p. 713-717, 2002.

70 BJERKE, D. L. Considerations for thermal injury: the elderly as a sensitive population. In: FARAGE, M. A.; MILLER, K. W.; MAIBACH, H. I. (Ed.). Textbook of aging skin. Heidelberg: Springer Science \& Business Media, 2010. cap. 16. p. 159171. 
71 YARMOLENKO, P. S. et al. Thresholds for thermal damage to normal tissues: an update. International Journal of Hyperthermia. v. 27, n. 4, p. 320-343, 2013.

72 MORITZ, A. R.; HENRIQUES, F. C. Studies of thermal injury: the relative importance of time and surface temperature in the causation of cutaneous burns. American Journal of Pathology, v. 23, n. 5, p. 695-720, 1947.

73 LI, L.; SO-LING N. G, C. A Physically-based human skin reflection model. Disponível em: $<$ https://pdfs.semanticscholar.org/412f/4ee7284bc9023a4eb2befca7f937b45701f0.pd f>. Acesso em: 30 out. 2016.

74 DILLER, K. R. Laser generated heat transfer. In: WELCH, A. J.; GEMERT, V.; MARTIN, J. C. (Ed.). Optical-thermal response of laser irradiated tissue. 2nd ed. New York: Plenum Press; 1995. cap. 10. p. 353-396.

75 DESAI, K. et al. Binding of apoE-rich high density lipoprotein particles by saturable sites on human blood platelets in hibits agonist-induced platelet aggregation. Journal of Lipid Research. v. 30, n. 6, p. 831-840, 1989.

76 MAYROVITZ, H. N.; REGAN, M. B. Gender differences in facial skin blood perfusion during basal and heated conditions determined by laser doppler flowmetry. Microvascular Research. v. 45, n. 2, p. 211-218, 1992. 
ANEXO A

$07 / 08 / 2017$

Câmera de Termografia Fluke Ti400 com Fluke Connect

\section{FLபKE.}

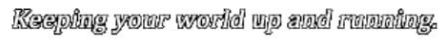

2

Procure na Fluke
Home | Produtos | Termovisores |

\section{Câmera de Infravermelho Ti400}

A Fluke Ti400 é perfeita para profissionais graças aos recursos de alto desempenho, como o foco velocidade e a preciš̄o desta moderna câm

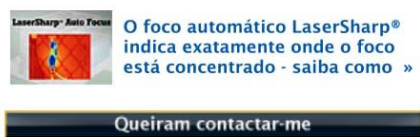

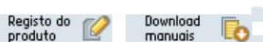

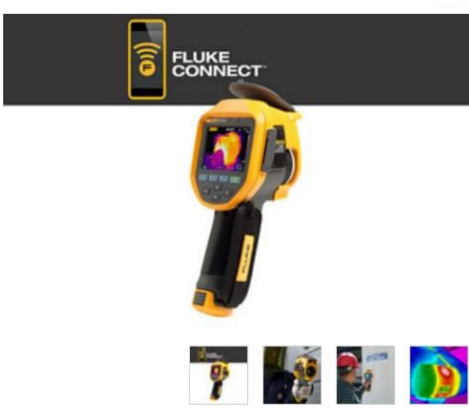

Equipamento Caracteristicas Especificaçōes Modelos e Acessórios Saiba mais

Especificaçōes detalhadas

Temperatura

$\begin{array}{lll}\begin{array}{l}\text { Faixa de medição de temperatura } \\ \left.\text { (sem calibração abaixo de }-10^{\circ} \mathrm{C}\right)\end{array} & -20^{\circ} \mathrm{C} \mathrm{a}+1200^{\circ} \mathrm{C} \\ \left(-4{ }^{\circ} \mathrm{F} \mathrm{a}+2192^{\circ} \mathrm{F}\right)\end{array}$

Precisão na medição da $\quad \pm 2{ }^{\circ} \mathrm{C}$ ou $2 \%$ (a $25^{\circ} \mathrm{C}$ nominais, o que for maior)

Correção de emissividade na tela Sim (por número e tabela)

Compensação da temperatura $\operatorname{Sim}$

Correção de transmissão na tela Sim

Desempenho de geração de imagens

Frequência de captura de imagens Taxa de atualização de $9 \mathrm{~Hz}$ ou de $60 \mathrm{~Hz}$ dependendo da variação do modelo

Tipo de detector

Sensibilidade térmica (NETD)

Total de pixels

FPA, microbolômetro não refrigerado, $320 \times 240$ pixels

Faixa espectral do infravermelho

Câmera visual (luz visivel) 76,800

$7,5 \mu \mathrm{m}$ a $14 \mu \mathrm{m}$ (ondas longas)

Tipo padrão de lente infravermelha

Campo de visão

Performance industrial 5.0 megapixels

$24^{\circ} \times 17^{\circ}$

\begin{tabular}{|l|l|}
\hline Resolução espacial (IFOV) & $1,31 \mathrm{mRad}$
\end{tabular}

\begin{tabular}{l|l}
\hline Distância minima do foco & $15 \mathrm{~cm}$ (aprox. 6 polegadas)
\end{tabular}

Lente de infravermelho telefoto opcional Tipo

\begin{tabular}{|l|l|}
\hline Campo de visão & $12^{\circ} \times 9^{\circ}$ \\
\hline
\end{tabular}

Resolução espacial (IFOV) $\quad 0,65 \mathrm{mRad}$

Distância mínima do foco $\quad 45 \mathrm{~cm}$ (aprox. 18 pol.)

Tipo opcional de lente infravermelha de ângulo amplo

\begin{tabular}{|l|l}
\hline Campo de visão & $46^{\circ} \times 34^{\circ}$
\end{tabular}

Resolução espacial (IFOV) $\quad 2,62 \mathrm{mRad}$

\begin{tabular}{l|l} 
Distância mínima do foco & $15 \mathrm{~cm}$ (aprox. 6 polegadas)
\end{tabular}

Mecanismo do Foco

\begin{tabular}{l|l}
$\begin{array}{l}\text { Sistema de foco automático } \\
\text { LaserSharp }\end{array}$ Sim \\
\hline Foco
\end{tabular}

Foco manual avançado Sim

Apresentação da imagem

Tons de cor

Padräo

Arco de ferro, vermelho-azul, alto contraste, âmbar, âmbar invertido, metal aquecido, escala de cinza, escala de cinza invertida \begin{tabular}{l|l}
\hline Ultra Contrast & TM \\
Âmbow Ultra, Vermelho-Azul Ultra, Alto contraste Ultra, Âmbar Ultra, \\
Âmbar invertido Ultra, Metal Aquecido Ultra, Escala de Cinza Ultra,
\end{tabular} Escala de Cinza Invertida Ultra

http://www.fluke.com/fluke/brpt/termovisores/fluke-ti400.htm?pid=77090

\section{$f t$ 畒 in}

Produtos relacionados

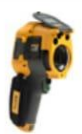

Câmera de Infravermelho Ti300 »

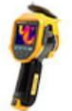

Termovisor Fluke Ti450»

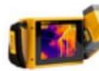

Câmera de infravermelho Fluke

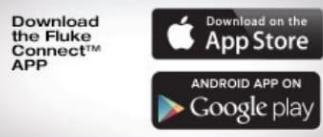

\section{Lentes IV.}

Veja o

impossivel.

De perto ou de longe com as lentes IV conseguia ver.

Ver o guia de selocia 
Nivel e abertura

tico suave e ajuste manual do nivel e da abertura

entre os modos manual é

entre os modos
automático

Reajuste automático rápido no

modo manual

(n)

Abertura min

Abertura mínima (no modo

automático)

Informação de IR Fusion ${ }^{\circledR}$

\begin{tabular}{|l|l} 
Picture-in-Picture (PIP) & Sim \\
\hline
\end{tabular}

Infravermelho em tela cheia

Modo AutoBlend ${ }^{\text {TM }}$

Alarmes coloridos (alarmes de Alta temperatura, baixa temperatura e isotérmica (selecionada pelo temperatura) usuário)

Captura de imagem e armazenamento de dados

Captura de imagens, visualização, Captura de imagens com uma só mão, visualização e recurso para

mecanismo para salvar salvar

Forma de armazenamento $\quad$ Cartão de memória Micro SD, memória flash on-board, capacidade de Cartäo de memória Micro SD, memória flash on-board, cap
salvar em USB, download direto por conexão USB com PC

Formatos de arquivos $\quad$ Não radiométrico (.bmp) ou (.jpeg) ou totalmente radiométrico (.is 2$)$

Não há necessidade de software de análise para os arquivos não radiométricos (.bmp e jpg)

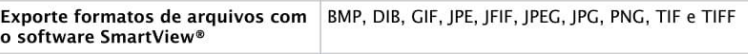

Visualização de memória Navegação com visualização em miniaturas e seleção de visualização

Outros recursos de produtividade e economia de tempo

\begin{tabular}{l|l} 
Anotação de voz & Tempo máximo de gravação de 60 segundos por imagem; reprodução
\end{tabular}

IR-PhotoNotes ${ }^{\mathrm{TM}} \quad$ Sim

Conectividade Wi-Fi

Anotação de texto"

Gravação em vídeo*

Transmissão de video para visualização no termógrafo

Sim, para PC, iPhone ${ }^{\oplus}$, iPad $^{\oplus}$ e WiFi para LAN

Sim

Padrão e radiométrico

Compativel com o Fluke Connect ${ }^{\oplus}$ Sim

Captura automática (temperatura e Sim

intervalo)*

Controle e operação remotos (para Sim

aplicaçōes especiais e avançadas)

Especificaçōes gerais

Temperatura de funcionamento

Temperatura de armazenamento

Umidade relativa

$10{ }^{\circ} \mathrm{Ca}+500^{\circ} \mathrm{C}\left(14^{\circ} \mathrm{F}\right.$ a $\left.122^{\circ} \mathrm{F}\right)$

$-20^{\circ} \mathrm{C}$ a $+50^{\circ} \mathrm{C}\left(-4{ }^{\circ} \mathrm{F}\right.$ a $\left.122^{\circ} \mathrm{F}\right)$ sem baterias

$10 \%$ a $95 \%$ sem condensação

Tela sensivel ao toque resistente

(capacitiva)

LCD VGA $(640 \times 480)$ horizontal, em cores; $8,9 \mathrm{~cm}(3,5 \mathrm{pol}) \mathrm{na}$

diagonal, com retroiluminaçăo

\begin{tabular}{l|l} 
Controles e ajustes & Escala de temperatura selecionável pelo usuário ( \\
\hline
\end{tabular}

Seleção de idioma

Configuração de data/hor

Seleção de emissividade

Compensação da temperatura refletida no plano de fundo

Correçăo de transmissão

Ponto quente e ponto frio selecionáveis pelo usuário, e ponto central

na imagem

Caixa de medição expansivel-retrátil com temperatura MíN-MÉD-MÁX

Alarmes de cor

Seleção de luz de fundo pelo usuário preferência de exibição das informacões gráficas

Preferência de exibição das informaçōes gráficas

Software SmartView e SmartView Mobile App - software completo de análise relatório incluso

Pilhas

Duas baterias inteligentes de lítio-íon recarregáveis com visor LED de cinco segmentos que indicam o nível de carga, todos os modelos

Vida útil da bateria Mais de quatro horas de uso cont
de brilho no LCD e uso médio)

Tempo de carregamento da bateria 2,5 horas para carga tota

Carregamento CA da bateria Carregador de bateria CA com dois encaixes (110 V CA a 220 V CA $50 / 60 \mathrm{~Hz}$ ) (incluido), ou carregamento interno ao termógrafo. Apcional de $12 \mathrm{~V}$ para carregar. Todos os modelos

Operação CA

Operaçāo CA com fonte de alimentação incluida (110 V CA a $220 \mathrm{~V}$ $\mathrm{CA}, 50 / 60 \mathrm{~Hz}$ ). Adaptadores $\mathrm{CA}$ de tomadas incluídos. 
07/08/2017

Economia de energia

Normas de segurança

Compatibilidade eletromagnética

C Tick

US FCC

Vibração

Choque

Queda

Dimensões ( $\mathrm{A} \times \mathrm{L} \times \mathrm{C})$

Peso (bateria incluída)

Classificação do quadro

Garantia

Ciclo de calibração recomendado

Idiomas
Câmera de Termografia Fluke Ti400 com Fluke Connect

Modos de suspensăo e desligamento selecionável pelo usuário UL 61010-1:2012 CAN/CSA-C22.2 No.61010-1-12 IEC 61010-1 3a Edição (2010)

EN 61326-1:2006 IEC 61326-1:2005

IEC/EN 61326-1

CFR 47, Parte 15 Subparte B Classe B

$0,03 \mathrm{~g} 2 / \mathrm{Hz}(3,8 \mathrm{~g}), 2,5 \mathrm{~g} \mathrm{IEC} 68-2-6$

$25 \mathrm{~g}$, IEC 68-2-29

Projetado para resistir a 2 metros ( 6,5 pés) com a lente padrão $27,7 \mathrm{~cm} \times 12,2 \mathrm{~cm} \times 16,7 \mathrm{~cm}(10,9 \mathrm{in} \times 4,8 \mathrm{in} \times 6,5 \mathrm{in})$

$1,04 \mathrm{Kg}(2,3 \mathrm{lb})$

IP54 (proteção contra poeira; entrada limitada; proteção contra borrifos de água vindos de todas as direçōes)

Dois anos (padrão), possibilidade de extensão da garantia.

Dois anos (considerando operação normal e processo normal de envelhecimento)

Tcheco, holandês, inglês, finlandês, francês, alemão, húngaro, italiano, japonês, coreano, polonês, português, russo, chinês simplificado, espanhol, sueco, chinês tradicional e turco

*Em breve por meio de atualização de firmware. Usuários notificados por meio do software SmartView quando disponivel.

Nem todos os modelos estāo disponiveis em todos os paises. Para obter mais informaçōes, consulte seu

(02017 Fluke Corporation. Todas as marcas comerciais são propriedade de seus respectivos titulares. Smartphone serviço sem fio e plano de dados não inclusos na compra. Os primeiros 5 GB de armazenamento são grátis. Samsung Galaxy S4 operando com Android 4.3.x ou superior e Samsung Galaxy S, Nexus 5, HTC One e One M8 operando com Android ${ }^{\text {Tm }}$ 4.4. $x$ ou superior. Apple e o logotipo Apple são marcas registradas da Apple Inc., registrada nos EUA e outros paises. App Store é uma marca de serviço da Apple Inc. Google Play é uma marc trada da Coogle Inc. 


\section{ANEXO B}

Av. Trabalhador săo-carlense, $400 / 13565-590$

Caixa Postal $369 / 13560-970$

Săo Carlos - SP. Brasil Fone: $+55163373-9758$ mun. ifsc usp br

\section{PARECER DA COMISSÃO DE ÉTICA PARA O USO DE ANIMAIS - CEUA/IFSC}

Protocolo $n=04 / 2014$

A Comissão de Ética para o Uso de Animais do Instituto de Fisica de São Carlos - CEUA/IFSC, em reunião realizada no dia 24.06.2014, aprovou o projeto de pesquisa intitulado "Desenvolvimento de nova técnica de diagnóstico para tumores não profundos a partir de medidas termográficas", submetido pela pesquisadora Mirian Denise Stringasci.

São Carlos, 03 de julho de 2014.

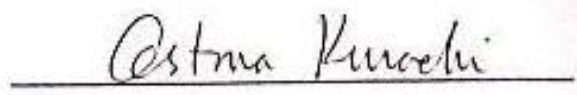

Profa. Dra. Cristina Kurachi

Presidente da CEUA/IFSC 
ANEXO C

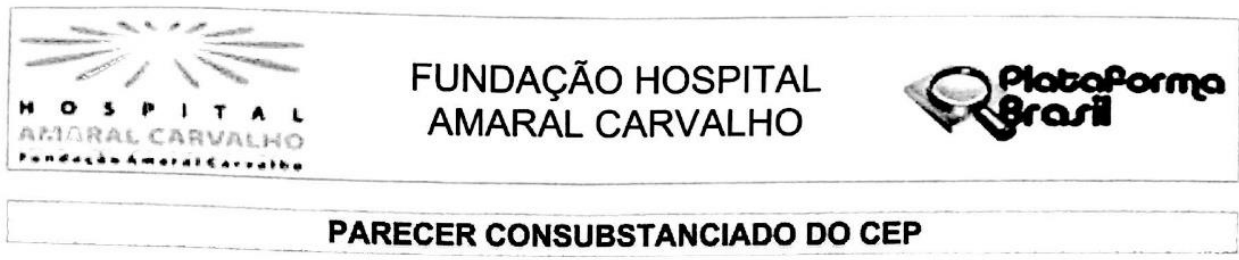

\section{DADOS DO PROJETO DE PESQUISA}

Título da Pesquisa: Avaliação termográfica de lesőes cutâneas

Pesquisador: ANA GABRIELA SALVIO

Área Temática: A critério do CEP

Versão: 3

CAAE: 37181314.0 .0000 .5434

Instituição Proponente: FUNDACAO DOUTOR AMARAL CARVALHO

Patrocinador Principal: Financiamento Próprio

\section{DADOS DO PARECER}

Número do Parecer: 1.171.682

Data da Relatoria: 31/07/2015

\section{Apresentação do Projeto:}

Não aplicável.

Objetivo da Pesquisa:

Não aplicável.

Avaliação dos Riscos e Benefícios:

Não aplicável.

Comentários e Considerações sobre a Pesquisa:

Não aplicável.

Considerações sobre os Termos de apresentação obrigatória:

Foi submetido novo TCLE que contempla as exigências éticas pertinentes ao estudo.

Recomendações:

Sem recomendações.

Conclusões ou Pendências e Lista de Inadequações:

Sem pendências.

Situação do Parecer:

Aprovado

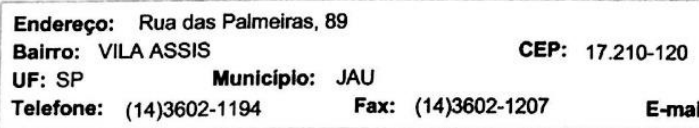




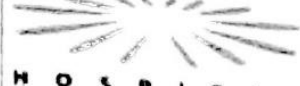

A S P I A

H....................

\section{FUNDAÇÃO HOSPITAL} AMARAL CARVALHO

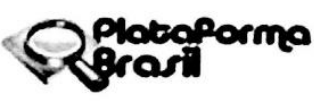

Continuaçấo do Parecer: 1.171 .682

Necessita Apreciação da CONEP:

Não

Considerações Finais a critério do CEP:

O colegiado acompanha o parecer do relator.

Solicitamos que antes de iniciar a pesquisa, o pesquisador encaminhe-se ao $\mathrm{RH}$ para providenciar o crachá para que seja permitida a sua entrada no Hospital.

Informamos que nenhum dos pesquisadores envolvidos no estudo participou da votação.

Aproveito para recordar-lhe do compromisso de enviar relatórios semestrais referentes à evolução do estudo.

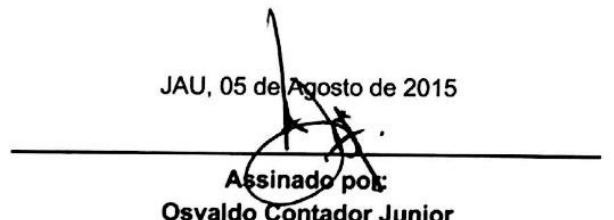

Osvaldo Contador Junior

(Coordenador)

Endereço: Rua das Palmeiras, 89

Bairro: VILA ASSIS

UF: SP Municipio: JAU

CEP: $17.210-120$

Telefone: (14)3602-1194

Fax: (14)3602-1207

E-mail: cep.aurea@amaralcarvalho.org.br 
ANEXO D

Contatos dos responsáveis pela pesquisa - Mirian Denise Stringasci (16) 33739810 (281) ou 992877097 Dra. Ana Gabriela Salvio: (14) 3626-6190.

TERMO DE CONSENTIMENTO LIVRE E ESCLARECIDO

Você está sendo convidada para participar de uma pesquisa clínica. Leia cuidadosamente o que segue e me pergunte sobre qualquer dúvida que você tiver. Após ser esclarecida sobre as informações à seguir e aceitando ser uma participante desta pesquisa, preencher e assinar as DUAS vias deste documento. Uma via pertence à você e a outra ao pesquisador responsável.

Título do Projeto: "Avaliação termográfica de lesões cutâneas"

Pesquisadores Responsáveis: Prof. Dr. Vanderlei Salvador Bagnato, Profa. Dra. Cristina Kurachi, Dra. Ana Gabriela Salvio e Mirian Denise Stringasci, Instituição do Pesquisador Responsável: Instituto de Física de São Carlos - Universidade de São Paulo

Contatos dos responsáveis pela pesquisa: Mirian Denise Stringasci: Av. Trabalhador São-carlense, 400, Grupo de Óptica, IFSC/USP, São Carlos-SP. Tel.: (16) 3373 9810, ramal 281/ 99287-7097; Dra. Ana Gabriela Salvio: Benedito Ferraz De Almeida Prado Jardim Santa Rosa, 301, Jahu-SP. Tel.: (14) 3626-6190.

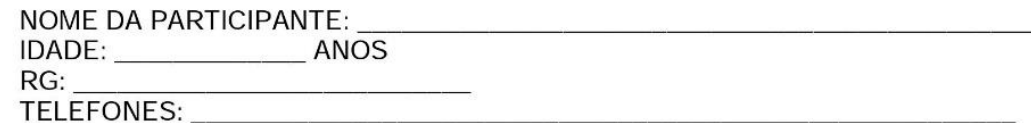

1. Justificativa e objetivos: É importante que se tenham avanços nas técnicas de diagnóstico para o câncer, doença responsável por $13 \%$ das mortes no mundo. As vantagens das imagens termográficas é que a técnica não é invasiva e não é depositado dose de radiação sobre o paciente. Além disso, esta técnica também pode ser utilizada no monitoramento da resposta da TFD, pois se sabe que um dos efeitos deste método alternativo para tratar tumor é o dano vascular na região tratada, que pode ser observado termicamente. E, então, podendo através deste monitoramento garantir a eficiência da técnica.

2. Procedimentos que serão utilizados na pesquisa: $O$ estudo será desenvolvido no Departamento de Pele do Hospital Fundação Amaral Carvalho em Jahu - SP. Serão adquiridas imagens térmicas das lesões para duas etapas distintas do estudo: distinguir lesões e avaliação à reposta da TFD. Estas imagens termográficas serão adquiridas por uma câmera de infravermelho Fluke ${ }^{\circledR}$ modelo FLK-Ti400.

Serão realizadas imagens de lesões de pele de pacientes através da câmera de infravelho. No total de 700 pacientes com diferentes tipos de lesões de pele, serão avaliadas a diferença de temperatura da lesão em relação ao tecido sadio, a possibilidade de determinar o tamanho da lesão e suas bordas através do mapeamento térmico. Em cada paciente também serão registradas imagens de tecido sadio contra lateral quando possível ou no mesmo sítio ativo para que possa ter um controle da heterogeneidade natural do tecido. E ainda, serão utilizados 20 voluntários de diferente faixa etária, sem lesões de pele aparente, para aquisição de imagens térmicas de diferentes regiões do corpo para que também possam ser usadas como controle.

As lesões que se enquadram no protocolo para realização da Terapia Fotodinâmica, com aprovação $n^{\circ}$ 140/11 do Comitê de Ética em Pesquisa da Fundação Hospital Amaral Carvalho, num total de 100 lesões serão adquiridas imagens pela câmera de infravermelho em diferentes fases durante as duas sessões do tratamento: lesão inicial, lesão curetada, após o tempo de incubação do medicamento, logo após a iluminação, 1 hora após e 2 horas após e, então, 30 dias após a segunda sessão. O procedimento de coleta de imagens termográficas realizado neste estudo não terá nenhum benefício e não irá alterar a rotina de diagnóstico e de tratamento definidos pelo seu médico.

3. Os desconfortos e riscos possíveis e os benefícios esperados: de acordo com o item $\mathrm{V}$ da Resolução CNS 466/2012, "considera-se que toda pesquisa envolvendo seres humanos envolve risco. O dano eventual poderá ser imediato ou tardio, comprometendo o indivíduo ou a coletividade". Ressalte-se ainda o item II.22 da mesma resolução que define como "Risco da pesquisa possibilidade de danos à dimensão física, psíquica, moral, intelectual, social, cultural ou espiritual do ser humano, em qualquer pesquisa e dela decorrente". Porém, ao voluntário deste estudo, o procedimento será exclusivamente a aquisição de imagens térmicas, sendo que a câmera utilizada apenas registra a irradiação infravermelha emitida naturalmente pelo próprio corpo. Este tipo de imagem é considerado não invasivo e não deposita nenhum tipo de radiação destrutiva ao tecido. Além disso, este estudo não interferirá na conduta médica durante ao atendimento e tratamento do 
paciente, pois as imagens serão posteriormente comparadas com o diagnóstico dado pelo dermatologista e arquivado em um banco de dados pelo pesquisador responsável.

4. Os métodos alternativos existentes: Os métodos comumente utilizados para diagnosticar lesões de pele, previamente, são análises clínicas e dermatoscópicas e, posteriormente, resultados de exame histopatológico obtidos por biopsias. Neste projeto buscaremos investigar a possibilidade de implementar a análise do mapa térmico junto ao exame clínico afim de se ter mais informações da lesões antes de se ter o resultado da biopsia.

5. A forma de acompanhamento e assistência, assim como seus responsáveis: obedecemos os Critérios da Ética em Pesquisa com Seres Humanos conforme Resolução CNS 466/2012, onde assumimos toda responsabilidade de dar assistência integral à participantes da pesquisa. As pacientes que vierem a sofrer qualquer tipo de dano resultante de sua participação na pesquisa, previsto ou não neste Termo de Consentimento Livre e Esclarecido, têm direito à indenização, por parte do pesquisador, do patrocinador e das instituições envolvidas nas diferentes fases da pesquisa (cobertura material para reparação a dano, causado pela pesquisa ao participante da pesquisa).

6. A garantia de esclarecimentos, antes e durante o curso da pesquisa, sobre a metodologia, informando a possibilidade de inclusão em grupo controle ou placebo: o participante e/ou seu representante legal deverão ter a garantia de todas as informações sobre esta pesquisa, metodologia e todos os procedimentos. Não aceite que as imagens sejam registradas sem antes tirar todas as dúvidas e ter todas as perguntas respondidas.

7. A liberdade do sujeito se recusar a participar ou retirar seu consentimento, em qualquer fase da pesquisa, sem penalização alguma e sem prejuízo ao seu cuidado: o participante poderá se recusar a participar desta pesquisa e/ou retirar sua participação à qualquer momento, sem constrangimento nem penalização. O paciente não terá nenhum tipo de despesa para participar desta pesquisa, bem como nada será pago por sua participação. Porém, este estudo poderá beneficiar a sociedade com uma nova ferramenta para discriminação de lesões de pele, caso seja comprovada sua eficiência.

8. A garantia do sigilo que assegure a privacidade dos sujeitos quanto aos dados confidenciais envolvidos na pesquisa: todas as informações pessoais coletadas neste estudo serão estritamente confidenciais, sendo assegurada ao participante a garantia de sigilo. Os dados serão anonimizados antes de serem encaminhados pela equipe médica responsável para qualquer outra instância, sejam outros pesquisadores ou o patrocinador. O participante deverá buscar indenização se sentir-se lesado ao participar da pesquisa, caso se sinta constrangido ou incomodado com alguma situação.

9. As formas de ressarcimento das despesas decorrentes da participação na pesquisa: as despesas decorrentes da sua participação, tais como transporte e alimentação, será ressarcidas ao participante. Além disso, o paciente não deverá abrir mão de seus direitos em caso de imperícia ou que se sinta prejudicado por qualquer motivo

10. As formas de indenização diante de eventuais danos decorrentes da pesquisa: a participante terá o direito à indenização financeira por parte do pesquisador, do patrocinador e das instituições envolvidas nas diferentes fases da pesquisa, no caso de se sentir prejudicada por ter participado desta pesquisa. Não renuncie em nenhum momento do seu direito de ser amparado.

11. Outras informações importantes: cabe ao Comitê de Ética em Pesquisa receber denúncias de abusos ou notificação sobre fatos adversos que possam alterar o curso normal do estudo, decidindo pela continuidade, modificação ou suspensão da pesquisa, devendo, se necessário, solicitar a adequação do Termo de Consentimento; os pesquisadores responsáveis deverão justificar fundamentadamente, perante o CEP (Comitê de Ética em Pesquisa) ou a CONEP (Comissão Nacional de Ética em Pesquisa), sobre a interrupção do projeto ou a não publicação dos resultados.

Diante dos esclarecimentos prestados, concordo em participar do estudo "Avaliação termográfica de lesões cutâneas".

Jahu, de de

Assinatura do participante 